Portland State University

PDXScholar

2009

\title{
Subordinate saints : women and the founding of Third Church, Boston, 1669-1674
}

Melissa Ann Johnson

Portland State University

Follow this and additional works at: https://pdxscholar.library.pdx.edu/open_access_etds

Part of the History of Religion Commons, and the Women's Studies Commons Let us know how access to this document benefits you.

\section{Recommended Citation}

Johnson, Melissa Ann, "Subordinate saints : women and the founding of Third Church, Boston, 1669-1674" (2009). Dissertations and Theses. Paper 3662.

https://doi.org/10.15760/etd.5546

This Thesis is brought to you for free and open access. It has been accepted for inclusion in Dissertations and Theses by an authorized administrator of PDXScholar. Please contact us if we can make this document more accessible: pdxscholar@pdx.edu. 


\section{THESIS APPROVAL}

The abstract and thesis of Melissa Ann Johnson for the Master of Arts in History were presented August 25, 2009, and accepted by the thesis committee and the department.

COMMITTEE APPROVALS:

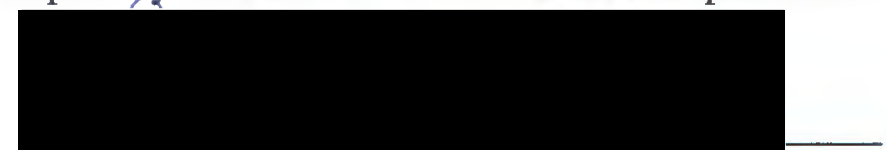

David Johnson, Chair

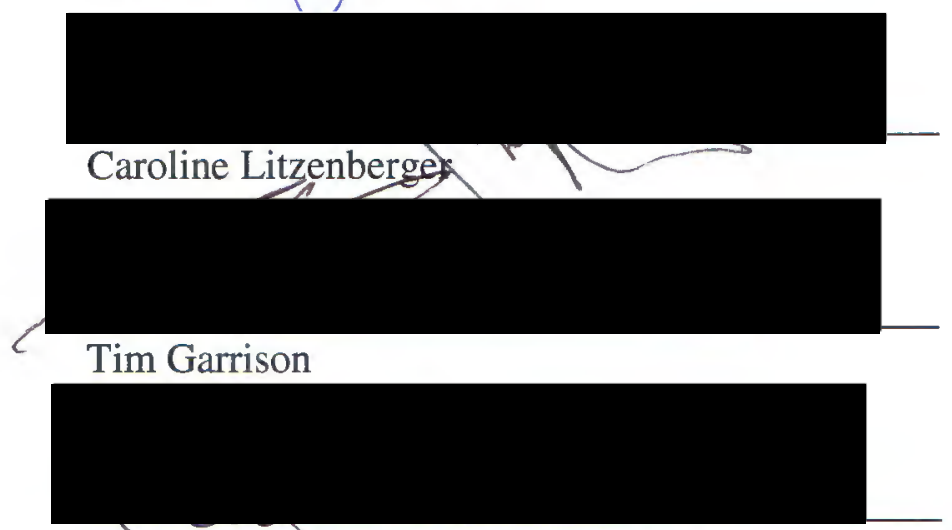

Carl Abbott

DEPARTMENT APPROVAL:

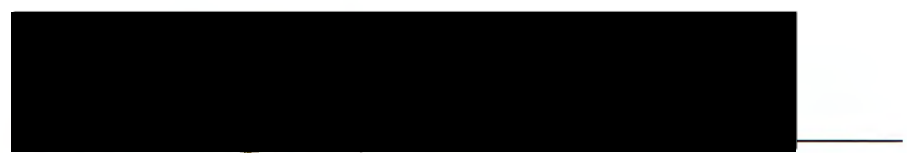

Thomas Luckett, Chair

Department of History 


\begin{abstract}
An abstract of the thesis of Melissa Ann Johnson for the Master of Arts in History presented August 25, 2009.
\end{abstract}

Title: Subordinate Saints: Women and the Founding of Third Church, Boston, $1669-1674$

Although seventeenth-century New England has been one of the most heavily studied subjects in American history, women's lived experience of Puritan church membership has been incompletely understood. Histories of New England's Puritan churches have often assumed membership to have had universal implications, and studies of New England women either have focused on dissenting women or have neglected women's religious lives altogether despite the centrality of religion to the structure of New England society and culture.

This thesis uses pamphlets, sermons, and church records to demonstrate that women's church membership in Massachusetts's Puritan churches differed from men's because women were prohibited from speaking in church or from voting in church government. Despite the Puritan emphasis on spiritual equality, women 
experienced a modified form of membership stemming from their subordinate place in the social hierarchy.

The Third Church schism provides a case study to illustrate women's lived experience as church members. After a group of dissenters broke away from First Church, Boston, and formed Third Church, their wives fought for five years to secure their own release from First Church. Despite the restrictions on women's activities in the church, the dissenters' wives were able to advocate for themselves and directly challenge their male superiors without transgressing boundaries on women's proper behavior. The women's efforts reveal that the patriarchy in New England was neither impenetrable nor absolute, but their reliance on men to advocate for them reveals that the patriarchy was real. Third Church's founding shows that women were not only actors in the private aspects of religion in Boston; they were also public actors.

Examining women's church membership allows a reappraisal of the Halfway Covenant's place in the history of Puritan New England. Women experienced limitations on their membership that reveal church membership to have been not one experience, but many. Rather than complicating what had previously been a clear distinction between members and non-members, the Halfway Covenant can be seen as adding a new type of membership added to a system which was already comprised of multiple categories. 


\section{'SUBORDINATE SAINTS' WOMEN AND THE FOUNDING OF}

THIRD CHURCH, BOSTON, 1669-1674

by

MELISSA ANN JOHNSON

A thesis submitted in partial fulfillment of the

requirements for the degree of

MASTER OF ARTS

in

HISTORY

Portland State University

2009 
For Agnes Johnson and Virginia Weiner

Cotton Mather called them "The Hidden Ones." They never preached or sat in a deacon's bench. Nor did they vote or attend Harvard. Neither, because they were virtuous women, did they question God or the magistrates. They prayed secretly, read the Bible through at least once a year, and went to hear the minister preach even when it snowed. Hoping for an eternal crown, they never asked to be remembered on earth. And they haven't been. Well-behaved women seldom make history; against Antinomians and witches, these pious matrons have had little chance at all.

Laurel Thatcher Ulrich 


\section{Acknowledgments}

This thesis took much longer to complete than was planned, and certainly longer than anyone would have wished, but I do not doubt that it was vastly improved by marinating in the kindness, good humor, and skeptical looks of the many people who encouraged me to keep wrestling with it. I have incurred numerous debts that I can never repay, so I offer these thanks as a small gesture of recognition for the generosity and tolerance I have been shown by friends, family, and faculty.

Kind words and challenging questions offered by early readers provided motivation at crucial moments. Anne Lombard gave helpful comments on a very early version of chapter one at the Western Association of Women Historians $39^{\text {th }}$ annual conference. Chapter three was much improved by thoughtful critiques from Laurie Hochstetler and Kyle Volk at the 2009 Phi Alpha Theta Northwest Regional Conference and from Fabio Lopez Lazaro at the 2009 meeting of the Pacific Coast Branch of the American Historical Association. Kyle Volk also jumped in during the final writing stages with invaluable guidance and emergency advising. Kenneth Lockridge gave a generous and careful reading to chapter three and the conclusion.

Instructors at Mt. Hood Community College nurtured and challenged me when I restarted my education after a gap of some years. Lidia Yuknavitch, Elizabeth Milliken, Gary Lovejoy, and especially Patrick Casey helped me believe that graduate school was possible. I have also been fortunate to study with the faculty of Portland State University's history department and have benefited from their tenacious commitment to both the department and its students. Thank you to my committee and 
other PSU faculty who have extended their time, advice, and encouragement: David Johnson, Caroline Litzenberger, Carl Abbott, Tim Garrison, Friedrich Schuler, David Horowitz, John Ott, John Mandaville, and Thomas Luckett. Thanks also to Jeff Brown, the history department's repository of administrative knowledge and keeper of the key, through whom all things are possible.

My peers (past and present) in the MA program and especially in the graduate colloquium have indulged me and helped me keep my sense of humor. Brittany Ferry, Michael Grutchfield, Adam Neff, Jamie Anderson, Dan Fellin, Erin McCullugh, Amy Platt, Lou Livingston, Manuel Herrera, Jeremy Piatt, James Hillegas, and Jenn Stanford-thank you for laughing at me and helping me laugh at myself. Special thanks to Marty Patail, who is convinced that he deserves it. I am wiser and more fun for having known all of you.

I am grateful for financial support for research and travel from the Caroline P. Stoel Endowment, the Caughey Foundation, the McNair Scholars Program, and the Portland State University Academically-Controlled Auxiliary Activities Fund.

Two extraordinary women have shared this journey with me and merit special thanks. Susan Wladaver-Morgan has offered guidance and friendship that sustained me in my darkest hours of doubt. My editing habit is her fault. Grammatical pet peeves not learned from Susan were imparted by Brittany Ferry. I am grateful for all the times we have giggled uncontrollably and inappropriately.

To David Johnson, who never admitted the despair he surely felt that this thesis would never be completed, I extend humble thanks for not giving up on me or 
on the Puritans. This project began in his undergraduate course on witchcraft, and neither of us could have predicted the devil that my ten-page paper on Sarah Good would spawn. He called me an expert long before I deserved it and gave me confidence that I might someday live up to that label. I could not have asked for a better mentor, cheerleader, or friend to guide me through the last long four years.

A special thanks to my family-to my brothers, Erick and Timothy, and especially to my parents, Ann and Allen Johnson-who understood when I chose the Puritans' company over theirs and who feigned interest in all things seventeenthcentury.

This thesis is dedicated to my grandmothers, "good wives" both, whose lives have inspired and informed my curiosity about history, women, family, and faith. As the keepers of our family histories, they told the stories that first sparked my interest in discovering the past. In more ways than I can name, my achievements are theirs. 


\section{Contents}

Acknowledgments ii

Introduction

"To walke in covenant with himselfe and with yourselves"

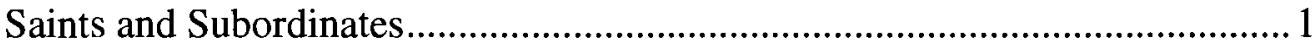

Chapter One

"To Eat and to Drink where she may not Speak"

Gender and Church Membership. 28

Chapter Two

"We cannot see our way cleare to so act with yourselves"

The Founding of Third Church, Boston 68

Chapter Three

"To provide for our own peace and spirituall comfort"

The Dissenting Wives of Third Church, Boston ....

Conclusion

"Wee ly under the same rule"

Competing Covenants

Sources Consulted 135

Appendix A

Timeline

Appendix B

Signatures on Wives' Petitions.

Appendix C

Admissions of New Members to First and Third Churches, 1667-1674 155 


\section{Introduction}

\section{"To walke in covenant with himselfe and with yourselves" Saints and Subordinates}

At the beginning of March 1669/70, twenty women submitted a letter to the elder of First Church, Boston, and asked him to relay it to the congregation for their consideration. The letter requested that the church release the women from their covenant and allow them to seek membership in the newly formed Third Church, which had been gathered by their husbands after a protracted battle with First Church. Though tensions were high between the two churches, the women nevertheless entreated the old church to help them prevent the "confusion, disorder, and disturbance" that would result from continuing in membership separate from their "deare husbands." The request was denied. The following month, after taking communion with their husbands at Third Church, the wives presented another letter asking the old church to let them follow their "own consciences" and join the covenant at the new church. Again, their request was denied. ${ }^{1}$ Though the women had tried to secure dismissions on the grounds first of their duty to their husbands and then of their duty to God, the old church refused to release them. Not only that, but the old church also declared the wives ineligible to participate in the Lord's Supper because they had worshipped with their husbands at Third Church. The women remained in this status-unable to take the Supper, and unable to leave the church-until 1674, some five years later.

${ }^{1}$ Dissenting wives to First Church, 5 March 1669/70, Third Church Narrative, in Hamilton Andrews Hill, ed., History of the Old South Church (Third Church) Boston, 1669-1884 (Boston: Houghton, Mifflin, 1890) [hereafter History of the Old South], 164-165; dissenting wives to First Church, 24 April 1670, in Third Church Narrative, 168. 
By the time the women sought their release, tensions had been building in Massachusetts Bay Colony's most prominent church for two years. The seeds of crisis had been planted when a small but significant minority of male church memberssignificant both in numbers and in social standing—challenged the church's choice of John Davenport to fill its pulpit because of his opposition to the Halfway Covenant, which extended baptism and church discipline to the children of those who had been baptized as children but were not yet in full communion. After less than a year, these dissenters gave up their battle for First Church and began to agitate for release from their covenant with that congregation; in May 1669 the rift between the "dissenting brethren" and the "major part of the church" was made permanent with the dissenters' establishment of Third Church.

It took the men nine months, from their first formal request for dismission to the day they signed the new covenant, to secure their liberty, but it would take their wives another five years to do the same. The dissenting brethren and their opponents in First Church were all men, and they came into battle with access to the same weapons. The dissenting men engaged in open debate with the elders of First Church during public meetings, enlisted the support of neighboring congregations, and solicited opinions from ministerial councils. ${ }^{2}$ The wives were disadvantaged in their

${ }^{2}$ Councils were a form of "inter-church cooperation" that were less formal and more common than synods. Synods were usually called by magistrates to resolve conflicts that affected all churches and were attended by large numbers of ministers and laymen; councils, on the other hand, were smaller gatherings and met at the request of particular churches seeking advice about disagreements that could not be resolved within the congregation. In both cases, the decisions rendered by the meetings were non-binding recommendations rather than enforceable orders, and the principle of consociation did not deprive individual congregations of their autonomy. See Mark A. Peterson, The Price of Redemption: 
efforts to secure their release: they could not employ public debate, they could not vote, and - because none of the women could vote-they could not enlist formal help from other women in the congregation. The women instead submitted letters, negotiated with the elders in private, and relied on the assistance of men who could more publicly agitate on their behalf. These women also made their voices heard through their actions, voting with their feet for the new church by attending both Sabbath services and the sacrament there, and they obtained an informal membership status in Third Church when First Church denied them release to seek formal admission.

The women's ability to do this stemmed from their dual roles as saints and as wives. Although they could not speak in church and had no voice in church government, the dissenters' wives were able to advocate for themselves and directly challenge their male superiors without transgressing boundaries on women's proper behavior. Puritan culture encouraged—even required—women to have knowledge of scripture and theology but denied them a public voice to assert judgments based on that knowledge. Women's involvement in the Third Church schism, however, showed that women could make decisions about their own religious practice, particularly when the instructions of their male superiors in the church conflicted with the choices made by their husbands, and that those decisions could lead to acceptable forms of public action.

The Spiritual Economy of Puritan New England (Stanford, CA: Stanford University Press, 1997), 37, 167; and Robert F. Scholz, "Clerical Consociation in Massachusetts Bay: Reassessing the New England Way and Its Origins," William and Mary Quarterly 29 (1972): 391-414. 
In a community comprised of the saving remnant, there should have been no tension between the individual and the community, since the sanctified would make right choices out of knowledge of truth. When this theoretical unity did not materialize in reality, however, church members made choices. Puritan assertions of individual spiritual autonomy collided with their belief in social hierarchyparticularly their inherited view of gendered hierarchy—and these two systems combined in the church to create both restrictions and opportunities. Because of their status as church members and as wives, women who had no official voice in either church or state nevertheless became major players in a crisis with colony-wide implications.

In the more than three hundred years since the establishment of Third Church, the schism in First Church has become a symbol of the theological and social transformations of Massachusetts Bay Colony in the wake of the Halfway Covenant. As a part of the debate over the extension of baptism, it joins the Antinomian crisis and the loss of the first charter to form a trilogy of controversies marking turning points in the evolution of Puritan New England. ${ }^{3}$ It is, like the Salem witchcraft crisis, "a lightning flash in the night: better to observe the contours of the landscape which it

\footnotetext{
${ }^{3}$ The Antinomian crisis of $1636-1638$ was the first major religious controversy in Massachusetts Bay Colony and centered on Anne Hutchinson's claim that the colony's ministers were teaching a covenant of works rather than a covenant of grace. Hutchinson and many of her followers were eventually banished from Massachusetts, and a resulting synod placed new restrictions on lay activities. See David D. Hall, ed., The Antinomian Controversy, 1636-1638: A Documentary History, $2^{\text {nd }}$ ed. (Durham, NC: Duke University Press, 1990). The original Massachusetts Bay Colony charter of 1629 was revoked in 1684 , depriving the colonists of the relative freedom from royal interference they had enjoyed for the first five decades of settlement. The new charter, enacted in 1692, ushered in a restructured colonial government under the Dominion of New England and imposed a new expectation of religious toleration on the colony. See Perry Miller, The New England Mind: From Colony to Province (1953; Beacon Press, 1961), chapter 11; and Peterson, Price of Redemption, 176-177.
} 
chances to illuminate." This thesis places the Third Church schism at its center, using it as a case study to illustrate the complexity of women's lived experience as church members in seventeenth-century Boston.

Becoming and being a member of one of New England's congregational churches during the seventeenth century was a gendered process. While each church member was a visible saint, individually covenanted with God and spiritually equal in his sight, membership conferred privileges and responsibilities that were contingent on the social status of the saint. Women could not access the privileges of sainthood that were incompatible with their roles as women and their church membership therefore fundamentally differed from that of their fathers, husbands, and sons. Some aspects of church membership were genderless: women and men had the same access to the sacraments, the same responsibility to demonstrate right behavior, and the same individually covenanted status. Some of the differences, such as separate seating arrangements and private confession, must have affected the way that women saw themselves within the context of the church. Another distinction, however, had undeniable consequences for women's lives as church members: Women were excluded from participation in church government. Government by the members, rather than by the clergy, was a fundamental component of the Puritan system, but

\footnotetext{
${ }^{4}$ Paul Boyer and Stephen Nissenbaum, Salem Possesssed: The Social Origins of Witchcraft (Cambridge, MA: Harvard University Press, 1974), xii.
} 
only male church members were allowed to engage in open debate and vote in church affairs. This meant that women were subject to the authority of ministers and elders whom they could not choose, and subject to discipline that they could not shape, despite being considered full members of the body of visible saints. The story of Third Church shows the practical, everyday significance of this difference for women's practice of their faith and their experiences as church members. When the dissenting wives sought dismissions from First Church, they were forced to contend with an authority structure that they had no direct hand in creating.

The patriarchal system of New England's churches was not absolute, however; women operated within a contradictory system as both saints and subordinates, and these contradictions created opportunities for them to define, to some extent, their own lived experience. A system of interlocking covenants and the practical limitations of New England's rigid hierarchical social structure led to continual renegotiation of practice. The women of Third Church were subject not only to the authority of the church, but also to their covenants with their husbands and their responsibilities as wives. When their church covenant proved incompatible with their commitments to godly marriages, the women were able to push against the boundaries of acceptable behavior for female church members in service of their marriage covenants. The church carefully avoided censuring the Third Church wives for their disobedience; there was a wide gulf between what the ministers, theologians, and magistrates proclaimed acceptable and what the community would and did accept—without lamenting the distance between theory and practice. Ministerial thetoric about 
covenants, families, membership, and gender were translated into everyday choices and experiences, and the dissenting wives' efforts to gain release from their covenant with First Church reveal the distance between the role definitions of a rigid theoretical hierarchy and the lived experience of women in that system. Women were an active part of church life within the orthodoxy despite limitations on their official involvement, and the boundaries around accepted behavior for their sex were less constricting than the idealized image may lead us to believe.

Although the privileges of church membership were diminished for women, the wives of the Third Church dissenters were able to work within those restrictions to advocate for their own release after their husbands had covenanted as a new church. Because they could not speak in church and could not cast votes in its government, the women advocated for themselves through letters, petitions, and private conferences. At first, they followed the instructions of First Church elders and ministers; when the women's efforts were refused they became defiant, but their defiance was exercised within the bounds of women's proper behavior. The dissenting wives' status as both individual saints and subordinate women placed restrictions on their actions but also created opportunities for them to act. Their final release from the covenant with First Church was accomplished not only through their own actions, however, but finally through the efforts of Third Church's minister and a council consulted by the men. The patriarchy may have been permeable, but it was not an illusion. 
None of the histories of the Third Church schism has afforded the same attention to the dissenting wives as the church's founders did. The seventeenthcentury chroniclers of the crisis considered the founding incomplete so long as the women were left stranded between the old church and the new, and they devoted many pages of their carefully documented Narrative to the five-year ordeal endured by the women. The nineteenth-century antiquarian who compiled Third Church's records for publication in 1890 echoed the founders' attention to the wives:

The faithful women who had to wait more than five years before they could become members of the new church, and who for a long time had no regular church standing whatever, deserve to be enrolled among the founders, and they should ever be remembered at the Old South with grateful respect and admiration for what they did and for what they suffered. ${ }^{5}$

Most historians who have examined the curious case of Third Church, however, have seen the women as a footnote, a distraction, or as only symbolic of the "real" story. For example, in a book devoted to the history of the Third Church, Ola Elizabeth Winslow merely noted that "the long delay before the wives could join as co-members

\footnotetext{
${ }^{5}$ Hill, History of the Old South, 120. The Third Church Narrative was written by four members of Third Church, three of whom were among the dissenting brethren. In addition to a narrative of the church's founding from 1667 to 1674, it also includes copies of letters, petitions, and other documents. Although the Narrative seems to have been written sometime around 1691, there is evidence that the authors began collecting information much earlier; a marginal note next to one of the wives' requests for dismission, dated March 5, 1669/70, says that "The 3d Church after great travell and trouble being furnished and supplyed with officers and ordinances did agree that there should be a narrative of the whole [pro]gres of their proceedings drawn up and kept among the Churches Records for Posterity." Third Church Narrative, 165. The Narrative was reprinted in Andrew Hamilton Hill's two-volume History of the Old South Church, published in 1890. Mark Peterson reviewed Hill's printed version against the original manuscript and found that Hill's text is accurate. Peterson, Price of Redemption, 252n22.
} 
with their husbands" was the only thing that "marred the serenity" of years that were otherwise characterized by "peace and quiet growth."

The dissenters' initial objection to Davenport's call was almost certainly centered on his vociferous opposition to the Halfway Covenant, and discussions of the Third Church schism are typically embedded in broader examinations of the innovation. A synod, or general meeting of the colony's ministry, had recommended the extension of baptism in 1662, but their recommendation was controversial and churches were slow to adopt the practice. The majority of ministers--with the notable exception of Davenport, among others—supported redefining the subjects of baptism as a means of bringing more of Massachusetts Bay's inhabitants under the watch and care of the church, particularly because membership numbers had been declining. Many church members, on the other hand, were reluctant to implement the innovation because they saw it as a threat to the purity of the churches. Beginning in the eighteenth century and continuing through a flurry of church histories in the nineteenth century, the keepers of New England's public memory described the dissenters and the majority facing off on either side of the baptismal divide, though some nineteenth-century writers were also attentive to other causes of the schism. ${ }^{7}$

${ }^{6}$ Ola Elizabeth Winslow, "And Plead for the Rights of All”: Old South Church in Boston, 1669-1969 (Boston: Nimrod Press, 1970), 36. Of course, her characterization of these years as quiet and peaceful is a little off the mark as well.

${ }^{7}$ Cotton Mather, Magnalia Christi Americana (Hartford, CT: Silas Andrus and Son, 1855), 2: 311-312; William Hubbard, A General History of New England from the Discovery to MDCLXXX [1680], Collections of the Massachusetts Historical Society, $2^{\text {nd }}$ series, 5 (1815; repr., New York: Arno Press, 1972), 601-602; William Emerson, An Historical Sketch of the First Church in Boston, From Its Formation to the Present Period (Boston: Munroe \& Francis, 1812), 111-121; Benjamin B. Wisner, The History of the Old South Church in Boston, in Four Sermons (Boston: Crocker \& Brewster, 1830), 
More recently, scholars have convincingly shown that, in addition to the undeniable pressure brought to bear by the Halfway Covenant, attitudes about royal interference, colonial politics, and toleration of religious radicalism were also important factors in the tensions that manifested in the controversy over Davenport's call to the First Church pulpit. These various debates converged upon the Third Church schism, which "firmed up alignments" among factions. ${ }^{8}$

This thesis narrows the scope of inquiry from the colony-wide conflict to focus on the dissenters, their wives, and the implications of their actions for our understanding of women's lives within the church. This is not to deny political and ecclesiastical impulses may have been at play—in seventeenth-century New England, it was nearly impossible to separate political, civil, and religious motives. While these aspects of the controversy are well-covered ground, the schism can also illuminate gendered aspects of New England church life that have thus far been largely unexplored. Three recent and very different studies have given some attention to the Third Church wives, but none of these works has fully realized the schism's potential

4-9; Joseph B. Felt, The Ecclesiastical History of New England; Comprising not only Religious, but also Moral, and other Relations (Boston: Congregational Library Association, 1862), 2:421, 435-438, 466; John Gorham Palfrey, History of New England during the Stuart Dynasty (Boston: Little, Brown and Company, 1882), 3:82-88; Henry Martyn Dexter, The Congregationalism of the Last Three Hundred Years (New York: Harper and Brothers, 1880), 468-474; George E. Ellis, History of the First Church in Boston, 1630-1880 (Boston: Hall and Whiting, 1881), 115.

${ }^{8}$ Robert G. Pope, The Half-Way Covenant: Church Membership in Puritan New England (1969; Eugene, OR: Wipf and Stock Publishers, 2002), chapters 5 and 6; Janice Knight, Orthodoxies in Massachusetts: Rereading American Puritanism (Cambridge, MA: Harvard University Press, 1994), 184-197; Richard C. Simmons, "The Founding of the Third Church in Boston," William and Mary Quarterly 26 (1969): 241-252; E. Brooks Holifield, "On Toleration in Massachusetts," Church History 38 (1969): 188-200; Stephen Foster, The Long Argument: English Puritanism and the Shaping of New England Culture, 1570-1700 (Chapel Hill: University of North Carolina Press, 1991), 188-189, 200207. 
to expand and deepen our understanding of women in Boston's congregational churches. In his comparative study of the relationship between spirituality and economic resources in New England's churches, Mark A. Peterson described the wives' membership crisis as a problem primarily for families. He concluded that "the members of the First Church were willing to risk family divisions for the sake of the principle of church autonomy." Peterson embedded the story of the women in a larger narrative of the church's founding and specifically used it as an example of the difficulty Third Church had in achieving reconciliation with First Church. He connected the wives' struggle for dismission with First Church's "continuing opposition...to the more open and ecumenical principles of the Third Church" and did not provide a gendered analysis. ${ }^{9}$

The two other studies specifically focused on women in New England. Amanda Porterfield proposed a connection between the activities of the dissenters' wives and the prominent role women had played in First Church since its founding, particularly the old church's history of "censuring assertive women," but she did not

\footnotetext{
${ }^{9}$ Peterson, Price of Redemption, 46-47. While his discussion of the schism is notable for including the women at all, the wives warrant only portions of a handful of paragraphs, and his reading of the sources for these events is marred by oversights in his claim that the women were "exclude[ed] from the Lord's Supper and from baptizing the children born to them at this time." This assertion overlooks two important parts of the narrative. First, a statement in the Third Church Narrative preceding the wives' application for membership clearly states that the women were asking for admission "with them where they had enjoyed Communion all this time." (Third Church Narrative, 201; emphasis added.) Second, the claim that their children were denied baptism falls flat for reasons of both theology and demographics. Since the women were wives of Third Church members, any infant children would have been eligible for baptism in the new church under their fathers' covenants. However, the sketchy biographical details available indicate that most of the founders were beyond child-bearing age and were unlikely to have had infant children during these years, rendering this point mostly moot.
} 
fully explore that suggestion or draw convincing connections between Anne Hutchinson, Anne Hibbens, and the dissenting wives. She argued that the prominence of women in the schism and in the church can be seen not only in the length and drama of the dispute, but also in the rhetoric of female piety that was used throughout the conflict by both the men of First Church and the dissenters. Porterfield imputed perhaps more meaning to this language than is reasonable, however, given her own argument that images of women and female piety were common in New England texts and sermons (even in the absence of "female dissension"). ${ }^{10}$ Porterfield's larger theme focused on Puritan thought rather than Puritan practice, however, and this limited her analysis of the event. Leslie J. Lindenauer, on the other hand, examined the actions of the women and argued that the Third Church wives were "proclaim[ing] spiritual independence." While she rightly noted that "women exercised both indirect and direct authority as members of their community's churches," she underestimated the constraints placed on women by New England's patriarchal institutions. Lindenauer oversimplified the events of the schism and ignored the ways in which the women relied on male advocates, inaccurately concluding that American Protestantism's emphasis on individual salvation rendered the patriarchy powerless. ${ }^{11}$

${ }^{10}$ Amanda Porterfield, Female Piety in Puritan New England: The Emergence of Religious Humanism (New York: Oxford University Press, 1992), 7-10, 120-121.

${ }^{11}$ Leslie J. Lindenauer, Piety and Power: Gender and Religious Culture in the American Colonies, 1630-1700 (New York: Routledge, 2001), 50, 128-133. 
This inquiry takes as its starting point Laurel Thatcher Ulrich's oft-cited observation about "well-behaved" women and attempts to locate the lived experience of female members in New England's Puritan churches by reexamining normative behavior. ${ }^{12}$ The Third Church schism expands Ulrich's seminal study because it provides a rare look at well-behaved women's actions, allowing an examination of not just expectations or ideals but also practice —not only what was prescribed or praised, but also behavior. Unfortunately, the dissenting wives' voices are lost to history; they left no diaries and no letters in their own hands. This is necessarily, then, a story constructed through inference. While the documents detailing the women's actions were written by men and have inherent biases, they nevertheless provide a rare opportunity to investigate an extended incident from the seventeenth century in which well-behaved women play a dominant and visible role.

Another guiding principle is Patricia Crawford's assertion that "women could both accept beliefs about their inferiority and transcend them. They were neither passive nor oppressed victims, but rather human agents." ${ }^{13}$ The women who inhabit this story lived not on the margins of New England society but in the center, at a time when that center was being tested and contested. The case of Third Church provides a glimpse at women who were a part of the orthodoxy as it was then developing:

${ }^{12}$ Laurel Thatcher Ulrich, "Vertuous Women Found: New England Ministerial Literature, 1668-1735," American Quarterly 28 (1976): 20. 1 .

${ }^{13}$ Patricia Crawford, Women and Religion in England, 1500-1720 (London: Routledge, 1996), 
members of the established church, mostly situated within the merchant class, and aligned with ministerial opinion of the Halfway synod. These women did not challenge the structure of Puritan society, did not question theology, and did not undermine prevailing expectations of women-in fact, they embraced and defended them. The dissenting wives were able to define their lived experience as church members within their assigned roles rather than in opposition to them.

\section{A casual reader of colonial New England's history would be forgiven for}

having the impression that Anne Hutchinson, Mary Dyer, Mary Rowlandson, and Salem's witches were the only women in seventeenth-century New England. ${ }^{14}$ From

${ }^{14}$ These poorly behaved women are ubiquitous in general histories of Puritan New England. See, for example, Edmund S. Morgan, The Puritan Dilemma: The Story of John Winthrop $\left(2^{\text {nd }}\right.$ ed., New York: Longman, 1999); Morgan, Visible Saints: The History of a Puritan Idea (Ithaca, NY: Cornell University Press, 1963); and Francis J. Bremer, The Puritan Experiment: New England Society from Bradford to Edwards (Hanover, NH: University Press of New England, 1995). Samuel Eliot Morison included only one woman in his "gallery of our intellectual ancestors," despite his claim to have examined those who "represent the various aspects of life... which appear in the first fifty years of this colony." Samuel Eliot Morison, Builders of the Bay Colony (1930; Boston: Houghton Mifflin, 1958), preface. Perry Miller's work has been (and continues to be) the dominant force in shaping studies of Puritan New England; Anne Hutchinson, Mary Dyer, and Salem's witches make predictable appearances, but the culture that shaped the New England mind was presumed to be one of men. Perry Miller, Orthodoxy in Massachusetts 1630-1650 (1933; Gloucester, MA: Harvard University Press, 1965); Miller, Colony to Province.

Some studies have focused particularly on rebellious women. Anne Hutchinson has been the subject of several studies, including Emery Battis, Saints and Sectaries: Anne Hutchinson and the Antinomian Controversy in the Massachusetts Bay Colony (Chapel Hill: University of North Carolina Press, 1692); and Lyle Koehler, "The Case of the American Jezebels: Anne Hutchinson and Female Agitation during the Years of Antinomian Turmoil, 1636-1640," William and Mary Quarterly 31 (1974): 55-78. A compelling analysis of the Hutchinson affair can be found in Jane Kamensky, Governing the Tongue: The Politics of Speech in Early New England (New York: Oxford University Press, 1997), chapter 3. The danger of applying feminist theoretical approaches to seventeenth-century women is demonstrated in Ben Barker-Benfield, "Anne Hutchinson and the Puritan Attitude toward Women," Feminist Studies 1 (1972): 65-96. Primary-source material has been compiled in Hall, ed., The Antinomian Controversy. While many of the Antinomian studies use gender as a category of analysis, this has been less true of studies of Quakers and captives. An important exception is Mary Maples Dunn's comparative study of Quaker and Puritan women. Dunn, "Saints and Sisters: Congregational and Quaker Women in the Early Colonial Period," in "Women and Religion," special issue, American Quarterly 30 (1978): 582-601. See also Margaret H. Bacon, The Quiet Rebels: The Story of the Quakers in America (New York: Basic Books, 1969); and Carla Gardina Pestana, "The City 
the work of Ulrich and Margaret W. Masson, we know something of the idealized New England woman, the goodwife celebrated in sermons and prescriptive literature. ${ }^{15}$ An abundance of other studies have told the stories of prominent dissenting women—outsiders who made their mark on history by drawing the attention of those who used the pen to condemn their actions, women who pushed against the orthodoxy from the outside (or who were placed on the outside). ${ }^{16}$ Even studies that have focused on "ordinary" women have not escaped organizing their

on a Hill under Siege: The Puritan Perception of the Quaker Threat to Massachusetts Bay, 1656-1661," New England Quarterly 56 (1983): 323-353. John Demos used family as a tool of analysis for examining Indian captivity in Demos, The Unredeemed Captive: A Family Story From Early America (New York: Vintage, 1994). Mary Rowlandson's narrative of her captivity is widely read, and is one of the few female-authored sources from the seventeenth century. Mary Rowlandson, The Soveraignty and Goodness of God, Together, With the Faithfulness of His Promises Displayed; Being a Narrative Of the Captivity and Restoration of Mrs. Mary Rowlandson (Cambridge, MA: Samuel Green, 1682), Wing ( $2^{\text {nd }}$ ed.) R2093, Evans 332.

Perhaps the greatest body of literature featuring New England women focuses on the phenomenon of witchcraft accusations. A sampling includes Boyer and Nissenbaum, Salem Possessed; Ann Kibbey, "Mutations of the Supernatural: Witchcraft, Remarkable Providences, and the Power of Puritan Men," American Quarterly 34 (1982): 125-148; John Putnam Demos, Entertaining Satan: Witchcraft and the Culture of Early New England (Oxford, UK: Oxford University Press, 1982); Carol Karlsen, The Devil in the Shape of a Woman: Witchcraft in Colonial New England (1987; New York: W. W. Norton, 1997); Elizabeth Reis, Damned Women: Sinners and Witches in Puritan New England (Ithaca, NY: Cornell University Press, 1997); and Mary Beth Norton, In the Devil's Snare: The Salem Witchcraft Crisis of 1692 (New York: Vintage, 2002). Of these, Kibbey, Karlsen, and Reis focus most closely on the gendered aspects of witchcraft. The salience of witchcraft as a topic of historical inquiry is evidenced by a recent forum reassessing Boyer and Nissenbaum's study. "Forum: Salem Repossessed," William and Mary Quarterly 65 (2008): 391-534. Salem and Hutchinson persist in our public memory as well, aided by popular histories and fictionalized accounts that appeal to those outside academe. Marion L. Starkey, The Devil in Massachusetts: A Modern Enquiry into the Salem Witch Trials (1949; New York: Anchor, 1989); Arthur Miller, The Crucible (New York: Viking, 1953); Eve LaPlante, American Jezebel: The Uncommon Life of Anne Hutchinson, the Woman Who Defied the Puritans (New York: HarperSanFrancisco, 2005).

${ }^{15}$ Ulrich, "Vertuous Women Found"; Margaret W. Masson, "The Typology of the Female as a Model for the Regenerate: Puritan Preaching, 1690-1730," Signs 2 (1976): 304-315.

${ }^{16}$ The word "orthodoxy" is fraught with complexity in relation to American Puritan studies. While this thesis intends to take issue, to some extent, with Perry Miller's orthodoxy, the word is primarily used herein to describe the "mainstream," referring to general beliefs and attitudes that were accepted and promoted by the power structure of New England society. This orthodoxy contained a range of opinions on some issues, including disagreement about baptism. 
analyses around stories of heretics, witches, captives, and criminals; these outsiders stand in stark relief against the relative anonymity of the "good wives." 17 There is an implicit (or explicit) assumption that it was only extraordinary women who could make their voices heard above the patriarchy, and that these women surely did not represent the masses of women who remained properly silent. In her study of women in the early modern English church, Patricia Crawford noted that pious women seem to make "unexciting" subjects because "it seems as if the godly woman was the successfully socialized woman." 18 The enthusiasm deficit is matched by a scarcity of sources; the well-behaved woman has been silenced by history, in part, because she left so few traces behind. ${ }^{19}$ The memory of disruptive women, by contrast, is sustained by easily accessible church and court records in which the rebels escape anonymity.

The history of exceptional women can only take us so far. We can examine the ideal that women were urged to emulate, and we can attempt to discern standards

${ }^{17}$ Carol Berkin plainly acknowledged the dichotomy with the title of her chapter on seventeenth-century New England women: "Good Wives and Bad." Berkin, First Generations: Women in Colonial America (New York: Hill and Wang, 1996), chapter 2.

${ }^{18}$ Crawford, Women and Religion in England, 4; emphasis added. Anne Braude has warned that "women's significance in groups considered marginal must not be allowed to obscure their centrality in maintaining what scholars traditionally have called the "mainstream." Braude, "Women's History Is American Religious History," in Retelling U.S. Religious History, ed. Thomas A. Tweed (Berkeley: University of California Press, 1997), 90.

${ }^{19}$ Laurel Thatcher Ulrich noted that no women's diaries from the seventeenth century can be found in the archives, and women authored few other works in that period. Ulrich, Good Wives: Image and Reality in the Lives of Women in Northern New England, 1650-1750 (New York: Vintage, 1991), 5. Her discussion of ways to access women's histories despite the lack of female-authored sources can be found in Ulrich, "Of Pens and Needles: Sources in Early American Women's History," Journal of American History 77 (1990): 200-207. 
of propriety by examining the basis for criticisms of poorly behaved women and thereby approach a model of good behavior. ${ }^{20}$ Criticisms of unacceptable behavior or praise for ideal behavior can help us approach a picture of the women in between, but the gulf is wide. The focus on dissenters coupled with the explication of a maledefined ideal leaves an impression that the majority of women were deferential, dutiful masses trying silently, and sadly, to comply with impossible standards of thought and behavior. But somewhere between these extremes-between the well-behaved women and the pariahs, between the virtuous and the rebellious, between the victims and the radicals, between the acquiescent ideal and the punishable heretic-was where most New England women lived their lives. Considerations of women and gender in colonial New England have expanded our knowledge of legal and economic history as well as the history of the family and education, but there have not been adequate examinations of women in New England's Puritan churches-not dissidents or heretics, but ordinary women professing and practicing adherence to the faith of New England's founders. ${ }^{21}$

${ }^{20}$ The latter has been done very effectively in, for example, Monica DiCataldo Fitzgerald, "Wicked Hearts and Wayward Walking: Gender, Religion, and Identity in Early New England" (PhD diss., University of California, Davis, 2005); Karlsen, Devil in the Shape of a Woman; and Kamensky, Governing the Tongue.

${ }^{21}$ On women's legal and civic status, see Mary Beth Norton, Founding Mothers and Fathers: Gendered Power and the Forming of American Society (New York: Vintage, 1996); C. Dallett Hemphill, "Women in Court: Sex-Role Differentiation in Salem, Massachusetts, 1636 to 1683," William and Mary Quarterly 39 (1982): 164-175; Cornelia Hughes Dayton, Women before the Bar: Gender, Law, and Society in Connecticut, 1639-1789 (Chapel Hill: University of North Carolina Press, 1995). On women's economic activities, see Ulrich, Good Wives, chapters 1 and 2; Jeanne Boydston, Home and Work: Housework, Wages, and the Ideology of Labor in the Early Republic (New York: Oxford University Press, 1990); and James E. McWilliams, "'To Forward Well-Flavored Productions': The Kitchen Garden in Early New England," New England Quarterly 77 (2004): 25-50. On family, see 
A remedy has been attempted by some, most notably Ulrich and Mary Beth Norton, but the problem of well-behaved women remains. ${ }^{22}$ Two very different approaches have attempted to reposition well-behaved women within the narrative of New England's Puritan past. The first, a series of intellectually oriented studies, has examined the rhetoric of Puritan ministers and found significance both in the content of elegiac sermons about women and in the use of female imagery. Studies of ministerial rhetoric and prescriptive literature have provided a useful portrait of the model goodwife; these studies have drawn attention to seventeenth-century gender distinctions, pointed to rhetorical patterns that reveal which of women's roles had the most public value, and complicated our understanding of Puritan gender roles. ${ }^{23}$ What they cannot tell us, however, is the extent to which women either tried or succeeded in embodying any of these ideals.

Edmund S. Morgan, The Puritan Family: Religion and Domestic Relations in Seventeenth-Century New England (1944; New York: Harper \& Row, 1966); John Demos, A Little Commonwealth: Family Life in Plymouth Colony (London: Oxford University Press, 1970); Anne S. Brown and David D. Hall, "Family Strategies and Religious Practice: Baptism and the Lord's Supper in Early New England," in Lived Religion in America: Toward a History of Practice, ed. David D. Hall, 41-68 (Princeton, NJ: Princeton University Press, 1997). On education, see David D. Hall, Worlds of Wonder, Days of Judgment: Popular Religious Belief in Early New England (Cambridge, MA: Harvard University Press, 1989), chapter 1; Kenneth Lockridge, Literacy in Colonial New England: An Enquiry into the Social Context of Literacy in the Early Modern West (New York: W. W. Norton, 1974); E. Jennifer Monaghan, "Literacy Instruction and Gender in Colonial New England," American Quarterly 40 (1988): 18-41. Mary Beth Norton provided an excellent synthesis of scholarship on colonial women in Norton, "The Evolution of White Women's Experience in Early America," American Historical Review 89 (1984): 593-619.

${ }^{22}$ Ulrich, Good Wives; Norton, Founding Mothers and Fathers.

${ }^{23}$ On the use of images of female piety, see, for example, Bremer, The Puritan Experiment, 115; Amanda Porterfield, "Women's Attraction to Puritanism," Church History 60 (1991): 202; Masson, "The Typology of the Female as a Model for the Regenerate," 309-315; Ulrich, "Vertuous Women Found"; and Porterfield, Female Piety, 7-10. 
The second approach is grounded in social history, illuminating women's roles as wives and mothers within the larger scope of family studies. Studies of New England families have shared a tendency to discuss women relationally; that is, observations about women are made primarily about their relationships with men. ${ }^{24}$ This is in some ways appropriate, since Puritans defined their social roles in terms of covenants and mutual responsibilities. We learn much about women's roles within households from these studies, but we often learn much more about their male counterparts. Exceptions to this approach have been studies that examine motherhood. Often these analyses have blended the intellectual approach with the social, examining the symbolic role that childbearing and motherhood played both in creating an image of the ideal Christian and in defining women's lives. ${ }^{25}$ These studies, again, help us fill in both the patterns of women's lives and the spiritual and temporal importance assigned to their roles as mothers, but tell us little about their experience within the church. General portraits of colonial women's lives have included some discussion of their roles as church members that serve as good starting points, but these overviews

${ }^{24}$ Edmund Morgan's ground-breaking study of the family did not have a particularly gendered approach, even when he was discussing marital or parental relationships. Morgan, Puritan Family, chapters 2 and 3. Studies that followed his example, such as those by John Demos and Philip Greven, gave more particular attention to domestic duties and patriarchal relationships, respectively. Demos, $A$ Little Commonwealth, chapter 5; Philip J. Greven, Jr., Four Generations: Population, Land, and Family in Colonial Andover, Massachusetts (Ithaca, NY: Cornell University Press, 1970), especially chapter 4.

${ }^{25}$ For example, see Martha Saxton, "Bearing the Burden? Puritan Wives," History Today 44 (1994): 28-33; and Ulrich, Good Wives, chapter 7. 
have not gone far enough in differentiating women's and men's experiences in their roles as visible saints. ${ }^{26}$

The Third Church controversy provides a view into women's lived experience in seventeenth-century New England by revealing their actions within the broader context of a church controversy. The women of Third Church survive in the records not because they were poorly behaved but because their actions were embedded in a larger male struggle, and the records left by these men allow an examination of the ways that the character of women's membership affected their practice within the church. The story of the dissenting women also parallels their husbands' earlier struggle with First Church and can therefore be viewed in comparison to male actions. Women's loyalties to both their faiths and their families were sometimes in tension, and this tension could both create options for women and trap them between male dominated institutions. That the dissenting women were wives is an important part of the Third Church story: They fought to leave their covenant with First Church, at least in part, because they were following their husbands to the new church, and they spent five years as hostages in a fight between the men of First Church and the men to whom they were married. Gerald F. Moran and Maris A. Vinovskis have suggested that a better understanding of New England Puritanism could result from exploring the intersections of family and religious life. ${ }^{27}$ This intersection is evident

\footnotetext{
${ }^{26}$ See, for example, Ulrich, Good Wives, chapter 12; and Berkin, First Generations, 41-42.

${ }^{27}$ Gerald F. Moran and Maris A. Vinovskis, "The Puritan Family and Religion: A Critical Reappraisal," William and Mary Quarterly 39 (1982): 30.
} 
in the Third Church schism, which shows how the relationship between the marital covenant, the church covenant, and the individual covenant with God could give women the opportunity to determine their own religious experience. This perspective provides an implicit reappraisal of Morgan's tribalism by reimagining the tensions in Puritan New England not as covenant versus family, but as covenant versus covenant, and suggests that church membership was from the beginning of settlement not one experience, but many.

The covenant that has gotten the most attention in studies of late-seventeenthcentury New England has been the Halfway Covenant, centered as it is within the ongoing debate over the declension narrative that has given shape to Puritan studies since it was articulated by Perry Miller. In this account, the first Puritan settlers of New England forged an orthodoxy that then slowly disintegrated as subsequent generations failed to live up to the founders' ideals. ${ }^{28}$ The Halfway Covenant, which defined a new category of membership, is positioned as a concession to this decline

${ }^{28}$ The declension motif was most successfully defined in Miller, Colony to Province, and in Sacvan Bercovitch, The American Jeremiad (Madison: The University of Wisconsin Press, 1978). The persistence of the declension narrative is remarkable; nearly all scholars who came after have confronted this narrative, either to endorse it or refute it. Good overviews of the debate can be found in Robert G. Pope, "New England versus the New England Mind: The Myth of Declension," Journal of Social History 3 (1969-1970): 95-108; Francis T. Butts, "The Myth of Perry Miller," American Historical Review 87 (1982): 665-694; Mark A. Peterson, "From Founding Fathers to Old-Boy Networks: The Declension of Perry Miller's Puritans," Reviews in American History 23 (1995): 13-19; Harry S. Stout and Catherine A. Brekus, "Declension, Gender, and the 'New Religious History,"' in Belief and Behavior: Essays in the New Religious History (New Brunswick, NJ: Rutgers University Press, 1991); and Charles L. Cohen, "The Post-Puritan Paradigm of Early American Religious History," William and Mary Quarterly 54 (1997): 695-722. 
and an abandonment, in some ways, of the errand in the wilderness. ${ }^{29}$ The Halfway Covenant has been seen as a major shift away from a dichotomy of member and nonmember, adding a liminal "halfway" membership status. While the Halfway Covenant expanded the available categories of membership, this thesis shows that the innovation was also situated within an extant spectrum of membership categories.

Halfway members were defined by their relationship to the church covenant; they fell in between those in full covenant with God and those who were outside of the fold. The church only drew official lines between full members, halfway members, and non-members, but there were other distinctions that related not to the member's relationship with God and the church, but to the member's place in the social hierarchy. Women simultaneously had both full membership (in terms of their covenant status) and partial membership (in terms of their privileges) because their place in the hierarchy did not allow them to exercise their full rights within the covenant. While not discounting the real distress that American Puritans—or at least their ministry-seem to have experienced when contemplating the extension of baptism, this analysis heeds Robert G. Pope's warning that historians have perhaps been too hasty when we "accepted at face value contemporary judgments of New

${ }^{29}$ The most thorough examination of the Halfway Covenant is Pope, Half-Way Covenant. Other useful accounts include Perry Miller, "The Half-Way Covenant," New England Quarterly 6 (1933): 676-715; Miller, Colony to Province, 95-114; Morgan, Visible Saints, 113-152; Foster, The Long Argument, 180-188; Brown and Hall, "Family Strategies"; Hall, Worlds of Wonder, 152-156; E. Brooks Holifield, The Covenant Sealed: The Development of Puritan Sacramental Theology in Old and New England, 1570-1720 (New Haven, CT: Yale University Press, 1974), chapters 5 and 6; Ross W. Beales, Jr., "The Half-Way Covenant and Religious Scrupulosity: The First Church of Dorchester, Massachusetts, as a Test Case," William and Mary Quarterly 31 (1974): 465-480; and James F. Cooper, Jr., Tenacious of Their Liberties: The Congregationalists in Colonial Massachusetts (Oxford, UK: Oxford University Press, 1999), chapter 5. 
England's religious condition." ${ }^{30}$ Including women in a study of church membership gives us a much different picture than the dichotomous member/non-member distinction that the Halfway Covenant supposedly explodes. Examining congregational membership through a gendered lens reveals the very basis of congregational autonomy to be a myth—churches were not in fact governed by their covenanted saints, but only by the male portion of the membership. In this view, the Halfway Covenant is part of a broader conception of church membership that reveals how the individual's relationship with God and notions of spiritual equality were always contingent.

Reevaluating categories of membership also expands our understanding of lived religion in New England. Recent works by David D. Hall and Charles E. Hambrick-Stowe have reconsidered New England's religious past by focusing on the ways in which religious belief manifested in lay practice. ${ }^{31}$ Hall focused his attention on the experience of faith that took place outside of the official orthodoxy as it was then being established, including lay interpretations of faith within the meetinghouse. Hambrick-Stowe looked inside the orthodoxy at "the form, content, and spiritual impact of the worship and private devotional activity of seventeenth-century New Englanders." These works have shown that "religion encompassed a range of

\footnotetext{
${ }^{30}$ Pope, Half-Way Covenant, 9.
}

${ }^{31}$ Hall, Worlds of Wonder; Hall, ed., Lived Religion in America; Charles E. Hambrick-Stowe, The Practice of Piety: Puritan Devotional Disciplines in Seventeenth-Century New England (Chapel Hill: University of North Carolina Press, 1982). Jon Butler has also explored lay religious practice outside of the Puritan orthodoxy. Jon Butler, "Magic, Astrology, and the Early American Religious Heritage, 1600-1760," American Historical Review 84 (1979): 317-346. 
possibilities, some with the sanction of official religion and others not, or perhaps ambiguously so."32 The perspective of lived religion provides tools for uncovering how women in New England integrated official teachings into their lives and acknowledges that variations in practice could take place within the orthodoxy as well as around it. The dissenting wives of Third Church were solidly engaged in the work of the Puritan church and confronted a situation in which the teachings they had received could not be reconciled. The theological underpinnings of Puritanism can be used to examine the church as an institution, not just as an expression of faith. By assessing Puritan women's practices within the church generally, and then applying this evaluation to the Third Church schism, the religious lives of women in New England come into sharper focus.

The competing and contradictory covenants to which Puritan women were subject allowed their lived experience to transcend the firm boundaries set forth in the rhetoric of ministers and theologians. Covenants did not always fit together neatly, and covenants that were assumed to be interrelated and mutually supportive- the marriage covenant, the church covenant, and the individual's covenant with God-did not always agree. Women faced a challenge when these inconsistencies forced them to select between the directives of competing authorities. When the women of Third Church found themselves trapped between their covenanted church and the church of their husbands, the wives were forced to choose between them. Women's subjection

${ }^{32}$ Hall, Worlds of Wonder, 3-20; Hambrick-Stowe, Practice of Piety, vii; Hall, "Introduction," in Hall, ed., Lived Religion, viii. 
to male authority did not always preclude, and could sometimes create, opportunities for choice.

The Third Church schism is a particularly useful case study not only because it was rooted in the major theological conflict of the late seventeenth-century-the Halfway Covenant-but also because the dispute took shape in two distinctly gendered phases. Rather than reinforcing a dichotomy that pits men's public duties against women's private ones, Third Church's founding shows how women were actively involved in defining and redefining the New England Way; it was not just men who were negotiating and adapting principles into practice on the errand. ${ }^{33}$ Women's status within the church as both a majority of visible saints and as individuals in covenant with God gave them room to maneuver within gendered constraints. Women's ability to shape public events has often been obscured from view by history's focus on traditionally male routes to power; in that context, dissenters' and radicals' influence on public events is more obvious than the

${ }^{33}$ The public/private dichotomy has been convincingly deconstructed in the legal and economic realms by Ulrich, Good Wives, chapters 1 and 2; and Mary Beth Norton, "“The Ablest Midwife That Wee Knowe in the Land': Mistress Alice Tilly and the Women of Boston and Dorchester, 1649-1650," William and Mary Quarterly 55 (1998): 105-134. Mary Maples Dunn has convincingly argued that what has been defined as "declension"- by both the Puritans and those who study them-is a gendered concept. That is, "what was seen as 'declension' was only a loss of male piety." Dunn, "Saints and Sisters," 592. The metaphor of the errand is explained in Perry Miller, "Errand Into The Wilderness," William and Mary Quarterly 10 (1953): 3-32. See also Samuel Danforth, A Brief Recognition of New-Englands Errand into the Wilderness (Cambridge, MA: S. G. and M. J., 1671), Wing $\left(2^{\text {nd }}\right.$ ed. $)$ D175. 
goodwives' ${ }^{34}$ However, everyday women also influenced public life with their inconspicuous, daily choices.

This study begins with a general examination of women's church membership and then explores the Third Church schism from that perspective. Chapter one assesses the ways that women's membership both resembled and diverged from men's membership and the way that Puritans reconciled their theology with their patriarchal social structure. Chapters two and three discuss the Third Church schism. Chapter two provides an outline of the first phase of the conflict and describes the men's activities up to the founding of Third Church. Chapter three explores the second phase of the schism, in which the women became the focus, and shows how the women's actions were affected by their social condition as women, wives, and saints.

\section{Sources}

The first volume of Hamilton Andrews Hill's History of the Old South Church (Third Church) Boston, 1669-1884 contains the Third Church Narrative and other primary-source material interspersed with Hill's own analysis and commentary. For clarity, citations for the Narrative will be noted as such, and any citations to supplementary primary-source material inserted into the Narrative by either its authors or by Hill will be individually identified. Citations to Hill's analysis will be cited as

${ }^{34}$ Gerda Lerner, The Creation of Feminist Consciousness: From the Middle Ages to Eighteenseventy (New York: Oxford University Press, 1993), 248. 
History of the Old South. Although Hill's history was published in two volumes, only one is used in this study, and all page numbers should be assumed to refer to volume one. This source should not be confused with another short book called History of the Old South Church of Boston (1886), also evidently authored by Hill. ${ }^{35}$

Sources printed in the seventeenth and eighteenth centuries were accessed through two subscription databases: Early American Imprints, Series I: Evans, 16391800 (http://infoweb.newsbank.com) and Early English Books Online (http://eebo.chadwyck.com). Short title catalog information is provided for these sources. All citations for the William and Mary Quarterly are from the Third Series; this notation has been omitted from both footnotes and bibliographic entries.

\section{Orthography}

In quotations from seventeenth-century sources, abbreviations have been silently expanded and spelling has been altered to conform with modern usage only in cases where readability was affected. Original punctuation and italic emphases have been retained except where otherwise noted.

\section{Dates}

New England was still using the old-style calendar during the years of the Third Church schism, and dates have not been converted to the new style.

\footnotetext{
${ }^{35}$ [Hamilton Andrews Hill], History of the Old South Church of Boston (Boston: Published for the benefit of the Old South fund, 1886).
} 


\section{Chapter One}

\section{"To Eat and to Drink where she may not Speak" Gender and Church Membership}

Alice Stedman wanted to be a pious Christian, but continually found herself "unable to believe and walk as I should." Through prayer, scripture, and ministerial counsel, God showed her "the freeness of His love," but she repeatedly fell into doubt about his grace. She confessed this to her church and told them about her change of heart, which happened "in the midst of [a] sermon" when she found the "Lord had begun to humble and subdue and quicken and sanctify" her. After hearing her confession of how she came to believe, the Cambridge congregation voted to admit her to membership and she joined in covenant with them. ${ }^{1}$

Church membership was not easy to attain in Puritan Massachusetts. The process of soul-searching and public confession could be arduous and Puritan theology discouraged surety about one's state of grace. For those who sought and found signs of visible sainthood, and were willing to share them with their neighbors, the church offered access to privileges that were otherwise unavailable to Massachusetts's inhabitants. These included personal, spiritual, social, and civic privileges. The rights of membership were not universally available, however, even to those who had covenanted in full communion: Alice Stedman's opportunities to embrace fully the life of the church were fewer than those available to her husband John, who had also

\footnotetext{
${ }^{1}$ Confession of Alice Stedman, in George Selement and Bruce C. Woolley, eds., Thomas Shepard's "Confessions," Publications of the Colonial Society of Massachusetts, Collections 58 (Boston: The Society, 1981), 102-105.
} 
joined the Cambridge church in full membership. ${ }^{2}$ Women experienced a modified form of membership stemming from their subordinate place in the social hierarchy. Though the experience of church members was marked by three differences from that of non-members-participation in the sacraments, being subject to church discipline, and having a voice in the government of the church-women in full membership were prohibited from accessing formal power in the church, and their exclusion from church government affected their experience of all aspects of their religious practice.

New England's Puritans rejected the geographical parish system that held in old England and instead based their churches on voluntary associations grounded in individual membership. They sought to bring the visible church—-the membershipinto close approximation with the invisible church-those who were actually savedby limiting membership to those who could demonstrate some evidence of having received grace. God did not dispense grace to communities or to families, but only to individuals, and so membership in a Puritan church was available only to those who sought it as individual believers. Although, as Winthrop explained, God had decreed that "some must be rich some poore, some highe and eminent in power and dignitie; others meane and in subjection," grace was not dependent on social or economic

\footnotetext{
${ }^{2}$ John Stedman had come to New England as a servant, but through his church membership was able to become a freeman after being freed in his master's will and later served his community as a constable, selectman, and treasurer. Confession of John Stedman, in Selement and Woolley, eds., Thomas Shepard's “Confessions,” 102-105.
} 
status; God's grace was available to all and solely at his discretion. ${ }^{3}$ Though men were superior to women in marriage, and husbands "had the power to lead, to admonish, and to command their wives...[,] they did not have the power to save them."4

Women, however, joined churches through different means and operated as members with different privileges. Although New England Puritans believed in individual salvation and spiritual equality before God, restrictions placed on women's actions meant that female church members did not enjoy that same equality within their churches. There were subtle but important differences between men's and women's membership that had significance for women's lived experience within the church. Puritans did not define women's membership as a separate category, but their beliefs about the differences between men and women led them to modify both the means of achieving membership and the privileges granted with that status.

The gendered components of membership were predicated on one distinction: Women could not speak in church. This prohibition was based on 1 Corinthians 14:34

${ }^{3}$ Quote from John Winthrop, A Modell of Christian Charity (1630), in The Puritans: A Sourcebook of Their Writings, ed. Perry Miller and Thomas H. Johnson (New York: Harper \& Row, 1938), 1:195. John Cotton, The Way of the Churches of Christ in New England (London: Matthew Simmons, 1645), Wing ( $\left(2^{\text {nd }}\right.$ ed.) C6471. A good summary of individual membership can be found in Edmund S. Morgan, Visible Saints: The History of a Puritan Idea (Ithaca, NY: Cornell University Press, 1963), esp. chapters 1 and 3. See also Williston Walker, The Creeds and Platforms of Congregationalism (1893; Cleveland, OH: United Church Press, 1991), 3; and Anne S. Brown and David D. Hall, "Family Strategies and Religious Practice: Baptism and the Lord's Supper in Early New England," in Lived Religion in America: Toward a History of Practice, ed. David D. Hall (Princeton, NJ: Princeton University Press, 1997), 41-42, 44-49. Robert M. Kingdon argued that New England did not abolish the parish, but instead redefined it as "an ideological or social unit" rather than a geographical area. Kingdon, "Protestant Parishes in the Old World and the New: The Cases of Geneva and Boston," Church History 48 (1979): 291.

${ }^{4}$ Laurel Thatcher Ulrich, “John Winthrop's City of Women," Massachusetts Historical Review 
("Let your women keep silence in the churches: for it is not permitted unto them to speak, but they ought to be subject, as also the law saith"5). According to John Cotton, minister of Boston's First Church, a woman was expressly forbidden from speaking in two cases: she may not teach men, and she may not ask questions in the meetinghouse. She was forbidden to teach because it "is unlawfull for a woman to usurpe over the man," and also because "the woman is more subject to Error then the man" and "therefore might soone prove a Seducer, if shee became a Teacher." The second reason was related to the first: though she may seem to ask questions "under pretence of desire to learne for her own satisfaction," she might deviously intend to "Teach her Teachers; or if not so, yet to open a doore to some of her own weake and erroneous apprehensions, or at least soone exceed the bounds of womanly modesty."

A woman was permitted to speak when she was under questioning-"to give account of her offence"- and she was permitted to sing psalms "together with the rest of the Congregation." ${ }^{6}$ These boundaries were also articulated by Thomas Hooker, who added that women "may so speak, when their speeches argue subjection, and so suit

\footnotetext{
${ }^{5}$ Geneva 1599.
}

${ }^{6}$ John Cotton, Singing of Psalmes a Gospel-Ordinance (London: M. S. for Hannah Allen and John Rothwell, 1647), Wing ( $2^{\text {nd }}$ ed.) C6456, p. 42-43. Cotton's suspicion about a woman's intent in questioning her minister was likely influenced by his experience with Anne Hutchinson. See Richard D. Pierce, ed., The Records of the First Church in Boston 1630-1868, Publications of the Colonial Society of Massachusetts 39 (Boston: The Society, 1961) [hereafter First Church Records], 20-25; David D. Hall, ed., The Antinomian Controversy, 1636-1638: A Documentary History ( $2^{\text {nd }}$ ed., Durham, NC: Duke University Press, 1990). See also Charles E. Hambrick-Stowe, The Practice of Piety: Puritan Devotional Disciplines in Seventeenth-Century New England (Chapel Hill: University of North Carolina Press, 1982), 114. The prohibition on women teaching extended only to adult men; women were permitted, and encouraged, to teach their subordinate children and servants. 
their sexes." 7 The prohibition on women's speech directly or indirectly touched all aspects of their lived experience of religion within the church, from the personal piety of the sacraments to the public performance of sainthood.

\section{"the Lord inclined my heart this way" Becoming a Visible Saint}

The Puritans did not believe in a universal church, but instead gathered regenerate members out of the world into independent congregations; the "particular visible church" was a communion of visible saints. Each church was "a company of faithfull and holy people" who had chosen "to joyn willingly together in Christian communion and orderly covenant," and a believer was only a member of that particular congregation to which they had been admitted. Joining a church meant joining in covenant with its other members and into covenant with God, giving oneself up not only to him but also to the church. ${ }^{8}$ While admission meant temporal membership only in an individual church, this condition had greater spiritual significance than simply belonging to one congregation. It was a status that acknowledged Puritans' belief in predestination: Acceptance into church membership

${ }^{7}$ Thomas Hooker, A Survey of the Summe of Church-Discipline (1648; facsimile ed., New York: Arno Press, 1972.), part III: 6.

${ }^{8}$ John Davenport, The Profession of the Faith of That Reverend and worthy Divine (London: John Hancock, 1642), Wing ( $2^{\text {nd }}$ ed.) D364, p. 6-7; Richard Mather, Church-Government and ChurchCovenant Discussed (London: R. O. and G. D. for Benjamin Allen, 1643), Wing ( $2^{\text {nd }}$ ed.) M1270, p. 10-11; John Davenport, An Answer of the Elders of the Several Churches in New-England (London: T. P. and M. S. for Benjamin Allen, 1643), Wing (2 $2^{\text {nd }}$ ed.) M1270, p. 73; James F. Cooper, Jr., Tenacious of Their Liberties: The Congregationalists in Colonial Massachusetts (Oxford, UK: Oxford University Press, 1999), 15; Harry S. Stout, The New England Soul: Preaching and Religious Culture in Colonial New England (New York: Oxford University Press, 1986), 16-18. 
was validation that the minister, elders, and other church members believed the person was among the elect and had received the gift of grace. ${ }^{9}$

Leaving a church and joining a different one was much more than a simple transfer of membership. Once covenanted with a church, a member could not leave without being "dismissed"; the covenant could not be abandoned at a whim but could only be dissolved with the mutual consent of both parties. The church had a duty to ensure that the saint intended to seek membership in "a godly Church where he may be further edified" and not "some corrupt Assembly where he may be destroyed." Requiring members to justify their departures also prevented the "necessarie Ruine that may fall upon the Body, if every particular member should depart at his own pleasure." ${ }^{10}$ If the church was satisfied that the member's reasons and intent were "for his best comfort," the church elders would draw up a letter of dismission that would act as a recommendation to the new congregation. In most churches, these letters did not ease the membership requirements and the saint would have to go through the process of seeking membership in the new church as they had in the old. ${ }^{11}$

${ }^{9}$ The most thorough contemporaneous overview of New England's church practices is Thomas Lechford, Plain Dealing: or, Newes from New-England (London: W. E. and I. G. for Nath. Butter, 1642), Wing L810. Morgan's description in Visible Saints appears to be derived directly from Lechford's account, and this document forms the basis of many (if not most) of the other descriptions available in the secondary literature on the topic. Such reliance on one source is problematic in some respects. Although the general procedures are confirmed in other contemporary treatises on church government, some of the more detailed information is difficult to corroborate. Lechford was not an entirely unbiased source, either; he refused to become a church member and left New England in 1641. His pamphlet includes a list of eleven "things I misliked in the country" (56-58). Biographical information is in Miller and Johnson, eds., The Puritans, 2:401.

${ }^{10}$ Davenport, Answer of the Elders, 74-75.

${ }^{11}$ Cotton, Way of the Churches, 103-105. 
By the 1640 s, the process of admitting new members to the covenant had been regularized, and though there were minor variations between congregations there was consistency in certain fundamental aspects throughout the Puritan churches in Massachusetts. Those who sought membership were required to satisfy both themselves and the church members that they were among the elect, and this was achieved through private introspection and public confession. After receiving an experience of "worke of grace upon their soules," the potential member would approach the elders in a private meeting to relate this conversion experience and to be tested on knowledge of church doctrine. If the elders were satisfied, the prospective member was presented to the body of church members during a regular meeting. The assembled saints would hear the profession of faith and have the opportunity to give testimony in support of the aspiring member and to pose questions that might help confirm the confession's sincerity. If the assembled church members were also satisfied, they would vote on admission with a show of hands or would assent with silence. Approval of the candidate was followed by the new member's name being added to the formal church covenant. ${ }^{12}$

${ }^{12}$ Morgan, Visible Saints, 88-89; Thomas Lechford, Plain Dealing, 4-11; R. Mather, ChurchGovernment, 23-24. Charles Lloyd Cohen reconstructed this process in Cohen, God's Caress: The Psychology of Puritan Religious Experience (New York: Oxford University Press, 1986), 137-161. Patricia Caldwell analyzed extant conversion narratives as a literary form in Caldwell, The Puritan Conversion Narrative: The Beginnings of American Expression (Cambridge, UK: Cambridge University Press, 1983). Questions were probably not asked directly by the church members but were instead submitted to the elders, who then posed the questions during the public confession. Cohen noted that while it is clear women did not vote in admissions, there is some mystery about whether women were even allowed to be present at admission proceedings in some churches. He has found, however, that Wenham and Chelmsford allowed women to testify on behalf of candidates for membership. Cohen, God's Caress, 142n16, 144n25. 
The ban on women's speech in the meetinghouse caused modifications to their admission procedures. A man would be expected to "speaketh himselfe" before the congregation when he gave his profession of faith, but in John Cotton's Boston and in many other churches a woman would remain silent while her private confession was read aloud to the congregation by elders who had received it in private. ${ }^{13}$ This practice seems to have begun in First Church sometime after the admission of John Cotton and his wife, Sarah, in 1633. After he had made his profession to the congregation, Cotton asked that "she might not be putt to make open Confession \&c: which he said was against the Apostles Rule \& not fitt for women's modestye."14 The procedural difference for women was due not only to the scriptural prohibition against

${ }^{13}$ Lechford, Plain Dealing, 4-5, 7-8. Boston's First Church allowed both men and women to make private confessions to the elders when they were joining with letters of dismission from another church. See, for example, First Church Records, 37, 41, 46. Charles Cohen noted that the question of private or public confessions was "not entirely gender-specific," and he argued against assertions that women's private confessions were either a sign of "liberalization" in the churches or a "practical benefit" for women. Cohen, God's Caress, 144 and 144n24. Lechford observed that women's private confessions were specific to the Boston Church; at Salem, he wrote, women often related their own confessions before the church. By 1642 this appeared to be changing, however. The confessions of Salem women, when they were made by the women themselves, were made during a weekday meeting rather than on Sunday. Selement and Woolley posited that Thomas Shepard "permitted or perhaps required women to recite their confessions before the congregation" in Cambridge. However, they also admitted that this is only conjecture because, although "there is no indication that Shepard recorded the confessions in private with the intention of reading them before the congregation as was the common procedure for women candidates" and he "made no notations as to any of them being private," there is also no evidence that the women's confessions were given in public. See George Selement and Bruce C. Woolley, "Introduction," in Selement and Woolley, eds., Thomas Shepard's "Confessions," 22, 22n. Cotton Mather noted that Thomas Hooker likely allowed private confessions for all candidates for admission in Hartford, both men and women. Cotton Mather, "The Life of Mr. Thomas Hooker," Magnalia Christi Americana (Hartford, CT: Silas Andrus and Son, 1855), 1:349. The subject of women's professions was a hotly contested topic in Wenham. That church decided in 1644 to require public confessions, but then reversed itself and ordered private professions in 1656. John Fiske, The Notebook of the Reverend John Fiske, 1644-1675, ed. Robert G. Pope (Salem, MA: Essex Institute, 1974), 4, 106. Geographic differences in the way women became members may have been significant, but it is beyond the scope of this study to analyze these differences.

${ }^{14}$ John Winthrop, The Journal of John Winthrop, 1630-1649, ed. Richard S. Dunn, James Savage, and Laetitia Yeandle (Cambridge, MA: Belknap Press, 1996), 96. 
women speaking in church, but also to their nature as women which made this modification necessary:

[B]ecause we find it by experience, the feeblenesse of some, their shamefac't modesty and melanchollick fearfulnesse is such, that they are not able to expresse themselves in the face of a Congregation, and yet have the precious work of saving grace in their hearts, we are forced to take the expressions of such in private, and make report of them to the Congregation: and since this was necessary for some, and was warrantable for all, it's most without exception to receive all after the same manner, that so the infirmities of the weakest may be releeved, and the seeming exceptions of others also may be prevented. $^{15}$

Although New England's guiding explication of doctrine, the Platform of Church

Discipline (1649), did not specifically address the issue in terms of gender, it did make allowances for private confessions when the prospective member "through excessive fear, or other infirmity, be unable to make their personal relation of their spirituall estate in publick." 16 This statement would have justified exceptions to the requirement for public confession, including exceptions for women. Most churches, however, continued to require men to give public professions throughout the seventeenth century. ${ }^{17}$

${ }^{15}$ Hooker, Summe of Church-Discipline, Part III: 6; italics in original.

${ }^{16}$ Richard Mather, A Platform of Church Discipline (Cambridge, MA: S. G., 1649), Wing P2396, p. 17; italics in original.

${ }^{17}$ Patricia Caldwell and Charles Lloyd Cohen both found that the content of women's conversion narratives was not particularly gendered. Caldwell found that, unlike English women's narratives, New England women "seldom resorted to talk about children and childbirth; and though some of them mentioned their husbands, most neither dwelt on nor allegorized the experience of marriage." Caldwell, Puritan Conversion Narrative, 26. Cohen argued that, though women's narratives tended to be somewhat shorter, there was a "fundamental sameness of the conversion experience for each sex," showing that "the experience of grace submerges the peculiarities of gender." Cohen, God's Caress, 223. Boston's First Church did not officially permit private statements by men until 1679. First Church Records, 75. 
Church membership was an intentionally exclusive status, restricted to those who could and did demonstrate signs of grace. This corresponded with the Puritans' belief that only a remnant of humanity was truly saved. Church membership in New England was certainly not universal and acceptance into the covenant conferred benefits and privileges on the members that were otherwise unavailable to New England's settlers. ${ }^{18}$ Admission to church membership was a reflection of the saint's "direct, personal relationship with God."19 Ministers were very clear about this point, explaining that "Husbands cannot bring in their wives, nor wives their husbands,

${ }^{18}$ David Hall has asserted that this exclusivity-membership as a "rite of separation"-was a part of the "everyday meaning of religion" for New England Puritans. See David D. Hall, Worlds of Wonder, Days of Judgment: Popular Religious Belief in Early New England (Cambridge, MA: Harvard University Press, 1989), 117-118. Historians disagree about what proportion of New England's settlers were full church members. Thomas Lechford reported that "three parts of the people of the Country remaine out of the Church, so that in short time most of the people will remaine unbaptized." Lechford, Plain Dealing, 73. Estimates of church membership have ranged from just one-fifth of the population to 70 percent of the settlers, and the numbers varied over the course of the seventeenth century. As Edmund Morgan noted, Perry Miller's low estimate of one-fifth has been questioned by subsequent scholarship. Perry Miller, The New England Mind: From Colony to Province (1953; Boston: Beacon Press, 1961), 53; Edmund S. Morgan, The Puritan Family: Religion and Domestic Relations in Seventeenth-Century New England (1944; New York: Harper \& Row, 1966), 171. Lockridge's study of Dedham concluded that as many as 70 percent of adult males in that town were church members in 1648 , and 80 percent of children born between 1644 and 1653 were baptized and therefore had at least one parent who was a church member. This last statistic could be misleading, however, since it would include multiple children from each family and only counts how many were actually baptized but does not clarify how many children qualified for baptism. Kenneth A. Lockridge, A New England Town: The First Hundred Years: Dedham, Massachusetts, 1636-1736 (New York: W. W. Norton, 1970), 31. More interesting is Rutman's finding that 93 percent of the founding families of Boston were represented by at least one church member, and that nearly half of those were families in which both husband and wife were members. Darrett B. Rutman, Winthrop's Boston: Portrait of a Puritan Town, 1630-1649 (Chapel Hill: University of North Carolina Press, 1965) 58. Historians seem to agree that the proportion of the population in full membership decreased with the second and third generations, though they disagree on the exact numbers, the causes, and the significance.

${ }^{19}$ Marilyn J. Westerkamp, Women and Religion in Early America, 1600-1850: The Puritan and Evangelical Traditions (London: Routledge, 1999), 18. 
Parents their children, nor their servants." 20 This was not only a doctrinal principle, but also a belief revealed in practice. Thomas Lechford observed that "Sometimes the Master is admitted, and not the servant, \& e contra: the husband is received, and not the wife; and on the contrary, the child, and not the parent."21 A woman's entrance into the covenant was an individual process that reflected her own spiritual condition, and she would enjoy the same spiritual privileges as a man once accepted into the body of visible saints.

\section{"publick Ordinances in publick Assemblies" Sabbath and Sacraments}

Charles Hambrick-Stowe has identified a range of activities—sacraments, the Sabbath, public fast and thanksgiving days, and lectures-that comprised public worship in New England. Of these, the sacraments were "special" (as opposed to "ordinary") ordinances because they were "administered only on specially designated Sabbaths and were restricted to members of the church covenant," while the others were performed frequently and were "practiced by every member of the social covenant."22 The Puritans rejected the Catholic doctrine of works, in which seven sacraments (baptism, penance, anointing of the sick, the Eucharist, confirmation, marriage, and holy orders) were steps on the path to salvation. Instead, the Puritans

${ }^{20}$ John Cotton, The Covenant of Gods free Grace, Most sweetly unfolded, and comfortably applied to a disquieted Soul (London: M. S. for Iohn Hancock, 1645) Wing C6424, p. 5.

${ }^{21}$ Lechford, Plain Dealing, 12.

${ }^{22}$ Hambrick-Stowe, Practice of Piety, 93-103, 123-124. 
embraced a covenant of grace and recognized only two sacraments - baptism and the Lord's Supper - that were both considered to be seals of a covenant already joined rather than a means to grace. John Davenport explained that baptism was a "seale [of] our entrance, or initiation" into the covenant, and the Lord's Supper was "the Sacrament of our spirituall nourishment, and continuance therein." ${ }^{23}$ Participation in the sacraments was therefore limited to those recognized as members of the elect. Limiting the sacraments to church members and their children preserved both the integrity of the church and its independence, since the members of a church held the "keys" of church government. ${ }^{24}$ The administration and receiving of the sacraments were acts of both public and private significance. The sacraments' primary function was confirmation of personal salvation; performed publicly, however, they also confirmed the boundaries of the community of saints to both members and outsiders. Women's spiritual independence extended to participation in the sacraments-they participated in the Lord's Supper whether or not their husbands could partake, and a woman's membership qualified her children for baptism regardless of her husband's

${ }^{23}$ John Davenport, A Catechisme Containing the Chief Heads of Christian Religion (London: John Brudenell, 1659), Wing D357, p. 39. This and other catechisms describe the Supper as a memorial or remembrance and do not indicate a belief in any spiritual presence. Davenport, Catechisme, 42; John Cotton, Spirituall Milk for Boston Babes in either England. Drawn out of the Breasts of both Testaments, for their soules nourishment: But may be of like use for any Children (London: Henry Cripps, 1657), Wing ( $2^{\text {nd }}$ ed.) C6462A, p. 12.

${ }^{24}$ See Davenport, Answer of the Elders, 62-66; Robert G. Pope, The Half-Way Covenant: Church Membership in Puritan New England (1969; Eugene, OR: Wipf and Stock Publishers, 2002), 6; Morgan, Puritan Family, 135; Perry Miller, "The Puritan Theory of the Sacraments in Seventeenth Century New England," Catholic Historical Review 22 (1937): 409-425; and John Cotton, The Keyes Of the Kingdom of Heaven, and Power there of, according to the Word of God (London: M. Simmons for Henry Overton, 1644), Wing C6439, p. 8. For an overview of the benefits and exclusivity of membership, see Pope, Half-Way Covenant, 3-4. 
status. ${ }^{25}$ Though the family was the foundation of society, a "little commonwealth," married couples were regularly separated when the bread and wine were distributed, and more often it was the wife who remained in the meetinghouse and the husband who left.

While salvation was not hereditary, New England's theologians split this hair quite finely. Children could be baptized if at least one parent-either mother or father-was a member in full communion. Baptism was generally performed at the afternoon service on Sundays and could only be performed by ordained ministers. ${ }^{26}$ The public performance of baptism before the mixed congregation (both members and unregenerate) served as a reminder to the community of the parent's status within the church. Baptism had replaced circumcision as the seal of the covenant, and God's covenant with Abraham in the Old Testament had been a promise to both him and his "seed." Baptism was therefore not a means to membership but a sign that the children were already members, to some degree, under their parent's covenant. ${ }^{27}$ How full the

${ }^{25}$ On women's spiritual independence, see Selement and Woolley, eds., Thomas Shepard's "Confessions," 5; Francis J. Bremer, Shaping New Englands: Puritan Clergymen in SeventeenthCentury England and New England (New York: Twayne Publishers, 1994), 44; Westerkamp, Women and Religion in Early America, 17; Rutman, Winthrop's Boston, 256-257; and Roger Thompson, Women in Stuart England and America: A Comparative Study (London: Routledge \& Kegan Paul, 1974), 86. Thompson perhaps went too far in his assessment that "by being in this vital area no respecter of persons or of sexes" it was "thus subtly and unconsciously an underminer of that very patriarchalism it publicly championed" (86).

${ }^{26}$ Some churches evidently extended baptism to grandchildren of members even prior to the Halfway synod. See Brown and Hall, "Family Strategies," 52.

${ }^{27}$ Richard Mather, A Disputation Concerning Church-Members and their Children (London: J. Hayes for Samuel Thomson, 1659), Wing W1271A. Interestingly, Mather also argued that "adopted children and infant-servants" who were "regularly and absolutely subjected to the Government and dispose of such heads of Families as are in Church covenant" could also be baptized (19-20). For a summary of Puritan views on infant baptism and criticisms lobbed at them by Baptists, see E. Brooks 
children's membership was, and the exact definition of "seed," were the subject of perhaps more debate among New England's ministers than any other subject. The theological paradox inherent in their baptismal practice-a belief in regenerate membership coupled with the practice of infant baptism—had been unraveling nearly from the beginning of New England's settlement, and the Puritans finally confronted this contradiction through the compromise of the Halfway Covenant in 1662. This compromise declared that the proper subjects of baptism included the children of those who had been baptized but were thus far unregenerate, so long as the parent proved knowledge of doctrine and was not "scandalous in life."28

Restrictions on participation in the Lord's Supper were clearer. Only full church members who had passed the test of conversion were eligible to participate. This sacrament was performed more regularly than in the English church, between six and twelve times per year. Because recipients were expected to prepare for the administration with prayer and self-examination, ministers would announce and then remind the congregation of the impending administration beginning two weeks before the appointed day. Hambrick-Stowe pointed out that this would have made the Lord's Supper prominent in the minds of New England's congregants since, "if administered monthly, the Sacrament was either mentioned or administered on three weeks out of

Holifield, The Covenant Sealed: The Development of Puritan Sacramental Theology in Old and New England, 1570-1720 (New Haven, CT: Yale University Press, 1974), 143-159.

${ }^{28}$ Propositions Concerning the Subject of Baptism and Consociation of Churches, Collected and Confirmed out of the Word of God by a Synod of Elders and Messengers of the Churches in Massachusets-Colony in New-England (Cambridge, MA: S. G. for Hezekiah Usher, 1662), Wing ( $2^{\text {nd }}$ ed.) M2292, p. 19. 
four or five." The Supper, therefore, was a visible sign and reminder of the distinction between members who could participate and non-members who could not. This sacrament was also generally performed in a closed setting-non-members departed the meetinghouse before it was administered—and therefore demonstrably segregated the insiders from the outsiders when the time came for administration. ${ }^{29}$ Within the community of church members, hierarchical relationships were reinforced by seating patterns for congregants during regular services and the administration of the Lord's Supper. $^{30}$

The manifestation of social hierarchy in the meetinghouse's seating arrangements for both the sacraments and the regular services made these gendered public practices. Seating in the meetinghouse was a spatial representation of a hierarchy that churchgoers already knew to exist. ${ }^{31}$ Church officers were seated closest to the pulpit, non-members nearer the back, and the remainder of the congregation filled the space in between according to their age, economic status, and social station. Prior to the advent of family seating in pews in the early eighteenth century, women were "placed on the opposite side of the aisle from the men, wives in the same position in order as their husbands, and widows given a spot in relation to the

${ }^{29}$ The scriptural justification for limiting the sacraments to members is explained in Cotton, Way of the Churches, 67-69. Hambrick-Stowe, Practice of Piety, 123, 125, 206-218; Lechford, Plain Dealing, 17; Winthrop, Journal, 130; Holifield, Covenant Sealed, 159-161.

${ }^{30}$ Seating assignments were made by a seating committee, usually composed of elders, deacons, and other prominent men in the church. Holifield, Covenant Sealed, 159-160; Robert J. Dinkin, "Seating the Meeting House in Early Massachusetts," New England Quarterly 43 (1970): 452453. There is no indication that women were allowed to serve on seating committees.

${ }^{31}$ Susan Juster, Disorderly Women: Sexual Politics and Evangelicalism in Revolutionary New England (Ithaca, NY: Cornell University Press, 1994), 24. 
status of their late spouses." When the Lord's Supper was administered, the minister and elders sat at the table, the minister blessing and breaking the bread before passing it on to the elders and repeating the process with the wine; the remainder of the congregation seems to have stayed seated in their regular assigned places. The social hierarchy was also performed during the public offering of contributions, when "the Magistrates and chiefe Gentlemen first, and then the Elders, and all the congregation of men, and most of them that are not of the Church, all single persons, widows, and women in absence of their husbands, come up one after another" to make their offerings to the maintenance. ${ }^{32}$ Since attendance was technically required at Sabbath services for all community members-whether church members or no-seating in the meetinghouse would have been a regular, public, visual reminder of one's own and one's neighbors' standing in the community.

\section{"next day coming to one of the elders" Personal Piety}

Although women were church members with equal standing before God, in the hierarchical society of Puritan New England they were required to perform much of

${ }^{32}$ Rutman, Winthrop's Boston, 126; Dinkin, "Seating the Meeting House," 450-453, 456; Cotton, Way of the Churches, 68-69; Lechford, Plain Dealing, 16-18. Amanda Porterfield suggested that this seating arrangement "represented the prominence of women saints in New England society as well as the relatively intimate relationship that obtained between them and their minister," since the women were typically seated on the side closest to the pulpit. The opposite argument could also be made, however: Seating women on the right side of the church, "effectively nestling the pulpit in the laps of the women," could also indicate that the Puritans considered women to be more in need of the ministers' message. Amanda Porterfield, "Women's Attraction to Puritanism," Church History 60 (1991): 197. It is important, perhaps, that women's contributions were individual and were not made by their husbands. See Fiske, Notebook, 180; Laurie Hochstetler, "Sacred Rites: Religious Rituals and the Transformation of American Puritanism" (PhD diss., University of Virginia, 2007), 117. 
their piety either in silence or in private. At the end of the regular services, if the sermon had not been over-long, time was allowed for congregants to ask questions of the minister or elders, and only women were excluded from this practice: "it may be lawfull for any (young or old) save onely for Women, to aske questions at the mouth of the Prophets." Instead, women were to reserve their questions for private conversations with their fathers, husbands, or ministers. Private conferences were a regular aspect of Puritan devotional practice. Meetings between congregant and minister were held to prepare for admission to membership, to offer prayers for the ill or spiritually troubled, for "spiritual progress or thanksgiving," and for discussions about child-rearing and parental prayer. Women also seem to have held private prayer groups in which they could discuss scripture and sermons more freely, but little about them is known. ${ }^{33}$

Though women were not permitted to question their ministers publicly, they were encouraged to study scripture, reflect on sermons, and ask questions privately to enhance their knowledge and understanding. New England's Puritanism emphasized the importance of scriptural study for all congregants, male and female. Despite the oft-cited passage from John Winthrop's journal in which the governor lamented the

${ }^{33}$ There was a scriptural basis for the restriction on questioning; 1 Corinthians 14:35 says, "And if they will learn any thing, let them ask their husbands at home; for it is a shame for women to speak in the church" (Geneva 1599). John Cotton, The True Constitution Of A particular visible Church (London: Samuel Satterthwaite, 1642), Wing ( $2^{\text {nd }}$ ed.) C6468, p. 5-6; Lyle Koehler, A Search for Power: The "Weaker Sex" in Seventeenth-Century New England (Urbana: University of Illinois Press, 1980), 30, 41; Hambrick-Stowe, Practice of Piety, 140-141, 152-155. The Antinomian controversy led to a stricter prohibition on women's activities in "mixed" meetings (where both men and women were present), and the synod of 1637 suggested that laity be allowed to publicly ask questions of their ministers only with the permission of the elders. Winthrop, Journal, 234. 
potential for "readinge \& writinge" to drive a woman insane, the studiousness of

Puritan piety and its personal character promoted literacy for both men and women.

Girls were taught to read, and even sometimes to write, so that they could personally engage with the Word. ${ }^{34}$

That women were knowledgeable about the Bible and that women were actively engaged with scriptural study can be seen in the confessions of faith recorded by Thomas Shepard at his Cambridge church. These confessions include nearly as many women as men, and both genders consistently cited and quoted specific Bible passages which aided in their realization of grace. When women mentioned the people who helped guide them to knowledge of the scriptures, these guides were often ministers or male relatives, but sometimes they were other women. ${ }^{35}$ While women's knowledge of scripture is not necessarily an indication of literacy, since memorization was common in oral/aural cultures such as New England, it does show that Puritanism

\footnotetext{
${ }^{34}$ Winthrop, Journal, 570; Ulrich, "John Winthrop's City of Women," 32; Dana Rose Comi, "“In the Shade of Solitude': The Mind of New England Women, 1630-1805" (PhD diss., Brandeis University, 2003), vii; Laurel Thatcher Ulrich, "Vertuous Women Found: New England Ministerial Literature, 1668-1735," American Quarterly 28 (1976): 25. Writing literacy was much less common among women than men, and Amanda Porterfield argued that it would have been much more likely among women of the wealthier social classes. Amanda Porterfield, Female Piety in Puritan New England: The Emergence of Religious Humanism (New York: Oxford University Press, 1992), 169n2. Porterfield relied on Kenneth Lockridge, Literacy in Colonial New England: An Enquiry into the Social Context of Literacy in the Early Modern West (New York: W. W. Norton, 1974) for her statistics, but Lockridge's low literacy numbers for women were convincingly questioned in E. Jennifer Monaghan, "Literacy Instruction and Gender in Colonial New England," American Quarterly 40 (1988): 18-41. Monaghan did agree, though, that both reading and writing literacy were functions of not only gender but also economic status $(25,33-34,36)$. For further discussion of literacy in New England, see also Hall, Worlds of Wonder, 32-33; Comi, "Shade of Solitude," 24, 34-38; and Mary Beth Norton, "The Evolution of White Women's Experience in Early America," American Historical Review 89 (1984): 607 and $607 \mathrm{n} 28$.

${ }^{35}$ See, for example, the confession of Katherine, a servant, who remembered that "First I went on in ignorance and had no means of light. So I went to an aunt who did, and where I was made by her to seek the means." Selement and Woolley, eds., Thomas Shepard's "Confessions," 99.
} 
encouraged women to wrestle with the intellectual underpinnings of their faith and gave them some tools to engage actively with a theology that otherwise limited their participation in its intellectual life. ${ }^{36}$

\section{"to performe all duties of love and watchfullnesse" Church Government and Discipline}

Membership served a significant public function in the establishment and government of a church. Congregational churches were ruled by the body of visible saints, meaning that each church was independently governed by its own members. The church was not defined by the building, the minister, or the government; it was simply and only "a Communion of Saints, a Combination of faithfull godly men, meeting for that end, by common and joynt consent, into one Congregation." New churches were founded, or "gathered," by groups of laymen, and once established the body of saints made collective decisions (at least theoretically) about choosing officers, admitting new members, and administering discipline. ${ }^{37}$

New congregations were usually formed in New England in new communities located too far from established meetinghouses for reasonable travel, or when an established community had grown too large for its meetinghouse to hold them all. A small group of laymen, usually between seven and ten, would meet together for "prayer and spiritual conference" to establish the "spiritual good estate of one

\footnotetext{
${ }^{36}$ Ulrich, "John Winthrop's City of Women," 19; Norton, "White Women's Experience," 599; Comi, "Shade of Solitude," chapter 1.

${ }^{37}$ Cotton, Way of the Churches, 1, 59-64; Cotton, True Constitution.
} 
another." They then sought the permission of the civil government to establish a new church and invited neighboring ministers to assist in the establishment. Those representatives from nearby congregations would extend "the right hand of fellowship" to the new church, "testifying their proceedings to have been according to God." The founders, or "pillars," were the first to sign the church covenant and were responsible for identifying and calling a minister to serve their new congregation. ${ }^{38}$ That the minister was officially called after the church was already established points to the importance of lay governance in Puritan churches-since ministers were only ordained in a particular congregation to which they were called, there could be a congregation without a minister but there could be no minister without a church. The laity retained the responsibility for calling officers as the church required, including ministers, ruling elders, and deacons. Elders were chosen from among the members, and ministers and elders were called by God to serve a church, but that calling was manifested by a vote of the other members.

Having made professions of faith and signed the church covenant, visible saints were also responsible for approving the admission of new members to the covenant. Through the admission of new members, and the discipline of existing members, the laity collectively set and maintained standards for piety and behavior. Only members could be brought before the church for disciplinary action, and members had the power to rule on matters of discipline, either directly by a vote or

${ }^{38}$ Cotton, Way of the Churches, 6-11. The minister-to-be was usually identified during the early stages of gathering and was part of the preparation, but was typically not ordained by the church until several months after the covenant was signed. See Hambrick-Stowe, Practice of Piety, 127-128. 
indirectly through the decisions of the elders whom they had approved. ${ }^{39}$ Church members could be censured by the congregation, and that censure could lead either to rehabilitation or to excommunication. Just as admissions were propounded publicly, so too were disciplinary decisions announced "in open Assembly" of the church; changes in a congregant's covenant status were of public concern and punishment was doled out "in full public view," allowing the full congregation to see the consequences of poor behavior. Excommunication need not be a permanent condition, howevershe or he could be brought back into the covenant if sufficient contrition was offered. ${ }^{40}$ Saints were also subject to less formal disciplinary actions. Keeping an eye on one's neighbors (so-called "watch and care") was an integral part of the covenant, and members became subject to what Darrett Rutman called a "continuous moral inquisition which was the meeting's duty to itself and to the community.",41

${ }^{39}$ Hambrick-Stowe suggested that the "admission of new members was in effect a reenactment of the first founding of the church." Hambrick-Stowe, Practice of Piety, 129-130. See also Cotton, Way of the Churches, 89-102.

${ }^{40}$ Examples of public disciplinary proceedings can be found in First Church Records, 37, 46. "Private sins" were dealt with in private conference and only "public sins" were publicly confessed. Cotton, True Constitution, 10-11. Monica DiCataldo Fitzgerald has noted that the public nature of disciplinary proceedings made them "lessons for the entire congregation, to encourage the entire community to walk orderly by using the sinner as an example." Fitzgerald, "Wicked Hearts and Wayward Walking: Gender, Religion, and Identity in Early New England" (PhD diss., University of California, Davis, 2005), 71-72. On the impermanence of excommunication, see David C. Brown, "The Keys of the Kingdom: Excommunication in Colonial Massachusetts," New England Quarterly 67 (1994): 531-566. On the ritual significance of censure, see E. Brooks Holifield, "Peace, Conflict, and Ritual in Puritan Congregations," Journal of Interdisciplinary History 23 (1993): 556-557. On patterns of discipline, see Fitzgerald, "Wicked Hearts and Wayward Walking." Whether the power of excommunication lay with the church or the minister was at times a hotly contested issue. There was debate among the ministers about whether the power of excommunication lay with the members as a whole or only with the elders, and not all churches followed the same guidelines. See Cooper, Tenacious of Their Liberties, 59-67. Churches also varied on whether votes needed to be unanimous or simple majorities. See Lechford, Plain Dealing, 14. 
Women were responsible for both understanding doctrine and following its tenets. Saints who failed to do so were equally subject to church discipline, regardless of gender. Discipline was a vital part of the Puritan church, and it was dispensed by the visible saints, who had a responsibility to assist their brethren and sisters in upholding the covenant. Saints were expected to demonstrate sanctification, or good behavior stemming from their salvation, and visible sainthood was just that: visible to neighbors, both members and unregenerate. While all saints were subject to discipline, and men were far more often the subject of censure, Monica DiCataldo Fitzgerald has found that women were censured for different transgressions and "confessed differently in front of their congregations." 42 According to Cotton, the prohibition against women speaking in church was lifted if they were brought before the congregation for disciplinary action:

When the Apostle forbiddeth women to speak in the church, he meaneth, speaking partly by way of authority, as in publick praying or prophesying in the Church, (1 Tim. 2.12.) partly by way of bold inquiry, in asking questions publickly of the Prophets in the face of the Church, 1 Cor. 14.34. But to answer it: If the whole Congregation have taken just offence at the open sin of a woman, she is bound as much to give satisfaction to the whole Congregation, as well as to the Presbyterie. ${ }^{43}$

Fitzgerald found that men were usually censured for public transgressions—-external failures"- and "asked for help from the community in fighting off sin as if it were an

${ }^{41}$ Darrett B. Rutman, American Puritanism: Faith and Practice (Philadelphia: J. B. Lippincott Company, 1970), 119; Davenport, Answer of the Elders, 72.

${ }^{42}$ Hambrick-Stowe, Practice of Piety, 130; Fitzgerald, "Wicked Hearts and Wayward Walking." 105.

${ }^{43}$ Cotton, Keyes of the Kingdom, $43-44$. 
outside attack" while women's censures focused on their "internal weaknesses" and their confessions centered on "personal reflection and piety." From her examination of Puritan censure patterns, Fitzgerald deduced that "men and women divided the covenant down gendered lines. ${ }^{44}$

Aside and apart from gendered perceptions of censurable offences, women's experience of discipline was also different than that of men, because while they were susceptible to it like other members, they had no voice in formulating the doctrine that governed such discipline and they were not given a vote in church matters. Votes of the members were necessary to approve the installation of ministers and elders, to accept new members into the covenant, to dismiss members who requested release from the covenant, and to censure or excommunicate wayward members. The scriptural admonition that women should not speak in church was extended to include voting because, as Richard Mather explained, "voting imports some kind of government, and authority and power: now it is not government and authority, but subjection and obedience which belongs unto women, by the rule, and so is the practice of women amongst us." 45

While each Congregational church was meant to be governed by its visible saints, this power was only intended for those who "according to God are onely

\footnotetext{
${ }^{44}$ While only "public" transgressions warranted examination by the entire church, these included sins that "disrupted the social order" and included a wide variety of offenses. Men were often censured for vice and for civic transgressions involving lawsuits, improper commercial activities, and property disputes, while women were more often charged with sexual offenses such as fornication and adultery. Fitzgerald, "Wicked Hearts and Wayward Walking," 70-71, 113-123.
}

${ }^{45}$ R. Mather, Church-Government, 60. 
capable thereof, to wit such Persons who are made able to receive this power, and to put forth the practice thereof." Women were excluded from this category, along with children and "mad Men." It went without saying that women could not be ministers, elders, or pillars, and freemanship—and therefore the civic franchise—was also available only to adult male church members. All rights of governing, voting, decision-making, and ruling were limited to adult men. ${ }^{46}$

Church membership was made a prerequisite for freemanship in Massachusetts Bay in the first decade of settlement. Puritan New England was not a theocracy; ministers could not also hold civil office and the civil government had no authority in doctrinal matters. After 1636, however, only members of churches which had been established with civic permission were legally qualified to become freemen. This system meant not only that magistrates were selected by church members, but also that

\footnotetext{
${ }^{46}$ Hooker, Summe of Church-Discipline, part I: 185-188; Cotton, Keyes of the Kingdom, introduction and 11-13. On freemanship, see Thomas Lechford, Plain Dealing, 23; Michael McGiffert, ed., God's Plot: Puritan Spirituality in Thomas Shepard's Cambridge (1972; Revised and expanded edition, Amhurst: University of Massachusetts Press, 1994), 147-148; and Carol Berkin, First Generations: Women in Colonial America (New York: Hill and Wang, 1996), 41. John Winthrop described a failed effort to found a new church in Salem that was rejected by the magistrates because the applicants were "but 3: men \& 8: women." Winthrop, Journal, 175.

Women were unequivocally excluded from serving as ministers or elders, but there was one position among the church officers that was reserved for women: Besides teachers, ruling elders, and deacons, Congregational doctrine recognized the office of widow or deaconess. John Cotton described widows as "Ancient women, well reported of for good workes, for nursing her children, for lodging of Strangers, for washing the Saints feet, for relieving the afflicted, for following diligently every good work." A widow's duties were formal expressions of the expectations of all women in Puritan society; the ministerial interpretation of biblical prescriptions indicated that widows were to "minister in the church, in giving attendance to the sick, \& to give succour unto them, \& others, in the like necessities." These were duties "which are not so fit for men to put their hands unto." Although official doctrine provided this role for women, the office does not appear to have been used in practice. Lechford observed that while churches varied in the numbers of elders and officers they maintained, "No Church there [New England] hath a Deaconesse, as far as I know." Lechford, Plain Dealing, 8, 15. John Cotton explained the absence of widows by stating that "wee finde it somewhat rare to finde a woman of so great an age as the Apostle describeth, to wit, of threescore years and withall, to be so hearty, and healthy, and strong, as to be fit to undertake such a service." Cotton, Way of the Churches, 39. R. Mather, Platform of Church Discipline, 12; Cotton, True Constitution, 4.
} 
only church members could serve as civil officers or jury members. The consequence was that whenever inhabitants were in the hands of justice, "when they come to be tryed there, be it for life or limb, name or estate, or whatsoever, they must bee tryed and judged too by those of the Church," whether or not they were church members themselves. Restricting civil affairs to church members effectively placed the test of civic character in the hands of church elders and congregations. ${ }^{47}$ Church membership was part of the path to social standing and civic engagement, and in both church affairs and civil government, one was sanctioned to speak with authority only after acceptance into the body of visible saints-and only if the saint was male.

${ }^{47}$ Perry Miller, Orthodoxy in Massachusetts 1630-1650 (1933; Gloucester, MA: Harvard University Press, 1965), 243; Edmund S. Morgan, Roger Williams: The Church and the State (New York: Harcourt, 1967), 76; Lechford, Plain Dealing, 23; Rutman, Winthrop's Boston, 137; Morgan, Visible Saints, 104-105; Pope, Half-Way Covenant, 41; Lockridge, New England Town, 23. This was true in Massachusetts Bay and later in New Haven. Connecticut, however, did not require church membership as a prerequisite for freemanship. See Morgan, Visible Saints, 108. The implications of linking freemanship with visible sainthood have been explored and debated in, for example, George Lee Haskins, Law and Authority in Early Massachusetts: A Study in Tradition and Design (New York: MacMillan, 1960), 25; Rutman, Winthrop's Boston, 55-57; Timothy H. Breen, "Who Governs: The Town Franchise in Seventeenth-Century Massachusetts," William and Mary Quarterly 27 (1970): 460474; B. Katherine Brown, "The Controversy over the Franchise in Puritan Massachusetts, 1954 to 1974," William and Mary Quarterly 33 (1976): 212-241; B. Katherine Brown, "Freemanship in Puritan Massachusetts," American Historical Review 59 (1954): 865-883; Stephen Foster, "The Massachusetts Franchise in the Seventeenth Century," William and Mary Quarterly 24 (1967): 613-623; Kenneth A. Lockridge and Alan Kreider, "The Evolution of Massachusetts Town Government, 1640 to 1740," William and Mary Quarterly 23 (1966): 549-574; Joshua Miller, "Direct Democracy and the Puritan Theory of Membership," Journal of Politics 53 (1991): 57-73; Richard C. Simmons, "Godliness, Property, and the Franchise in Puritan Massachusetts: An Interpretation," Journal of American History 55 (1968): 495-511; and Robert Emmet Wall, Jr., "The Massachusetts Bay Colony Franchise in 1647," William and Mary Quarterly 27 (1970): 136-144. 


\section{"the Duties belonging to every one" Patriarchy and Hierarchy}

The seeming contradiction between women's spiritual independence and their earthly submission was easily explained and understood by those who lived in a society ordered by strict notions of hierarchy. The Puritan God was "not the God of confusion, but of order" and therefore, as in an army, "each Person keeps his place \& posture. The power is in the whole firstly, but each part knowes his rank, and acts after his owne order and manner." This was a society in which hierarchy was ordained by God and considered to be the very foundation of the social and spiritual order. ${ }^{48}$ The hierarchical relationships that ordered New England society were rooted in the Puritans' understanding of the Fifth Commandment, which ordered believers to "Honour thy father and thy mother, that thy dayes may be prolonged upon the land, which the Lord thy God giveth thee." ${ }^{49}$ This directive had significance far beyond family relationships, however. Parents, in this Early Modern interpretation, were metaphors for one's superiors in general, and the commandment was understood to require "the preserving the Honour, and performing the Duties belonging to every one in their several Places and Relations, as Superiors, Inferiors, or Equals." ${ }^{, 50}$ All members of the community had mutual responsibilities as both superiors and inferiors, and the performance of those duties was a sign of respect for both the community and

\footnotetext{
${ }^{48}$ Winthrop, Modell of Christian Charity, 195-199; Hooker, Summe of Church-Discipline, part I: $185-186,188$.

${ }^{49}$ Exodus 20:12 (Geneva 1599).

${ }^{50}$ Samuel Willard, A Compleat Body of Divinity (1726; facsimile ed., New York: Johnson Reprint Corporation, 1969), 598.
} 
for God's law. ${ }^{51}$ Limitations on women's full participation as church members did not contradict a belief in spiritual equality; by faithfully living in the role that had been ordained for them, Puritans served God by submitting to the hierarchy. ${ }^{52}$

While all Puritans had a place in the hierarchy, of the free white inhabitants it was women whose lived experience of faith was restricted regardless of where else they might fall in the hierarchy. ${ }^{53}$ The settlers of New England had brought with them not only their religious convictions, but also an English world view. Scriptural commands of submission to authority confirmed an English custom in which "the great weight of public opinion deemed [women] mentally, morally, psychologically and physically inferior to men." While the Puritan understanding of the Fifth Commandment defined a series of dichotomous relationships—husband/wife, minister/layperson, master/servant, parent/child—women were always subordinated first as women. Women effectively occupied a parallel hierarchy wherein they were

${ }^{51}$ Willard, Body of Divinity, 598-600. See also Cotton, Spirituall Milk for Boston Babes, 4; Morgan, Puritan Family, 17-19.

${ }^{52}$ Carol Karlsen, The Devil in the Shape of a Woman: Witchcraft in Colonial New England (1987; New York: W. W. Norton, 1997), 164.

${ }^{53}$ White servants, Indians, and "negroes" were all permitted to join the covenant, but their experiences of church membership were very likely also restricted. On the social and economic mobility of servants, see Morgan, Puritan Family, 132. On efforts to Christianize Native Americans, see for example Cotton Mather, "The Life of John Eliot," in Magnalia, 1:526-583; and C. Mather, An Epistle To the Christian Indians (Boston: Bartholomew Green and John Allen, 1700), Wing M1178. A very few tantalizing clues suggest that more investigation should be done about both white servants and black church members. Some black servants were accepted as members of the Salem church, and Cotton Mather also published a pamphlet to "excite and assist that good work, of instruction of NegroServants in Christianity." Richard D. Pierce, ed., The Records of the First Church in Salem, Massachusetts 1629-1736 (Salem, MA: Essex Institute, 1974), 45, 53, 59; Cotton Mather, The Negro Christianized (Boston: B. Green, 1706), Evans 1262. See also Rutman, Winthrop's Boston, 146. Robert J. Dinkin found that Indians and black servants were often given the least prominent and therefore least desirable seats in the meetinghouses despite being "usually granted full religious privileges." Dinkin, "Seating the Meeting House," 457. 
subordinate to the men "of their rank." ${ }^{, 54}$ Puritan churches represented this by seating women separately from and parallel to men in the meetinghouse.

\section{"the travelling truth relating to duty unto the children of the Church" The Halfway Covenant}

Women's church membership allowed them access to the sacraments and made them subject to church discipline, but denied them a voice in church government. Their membership was a modified form of that enjoyed by men, who had full access to all of the rights and responsibilities conferred by their status as visible saints. Puritan doctrine did not officially distinguish women's membership as different in kind, however, and only defined a liminal category in 1662 when the socalled Halfway Covenant articulated a separate type of membership. ${ }^{55}$

The Halfway Covenant was officially adopted by a synod in 1662 , but the problem it tried to solve had emerged much earlier. Children of saints were baptized because they were already assumed to be under the covenant, but many baptized children of the founding generation grew to adulthood and failed to have experiences of saving grace (or at least, failed to volunteer to relate a conversion experience to the congregation). Puritan divines agreed that baptism did not excuse "children of the

${ }^{54}$ Thompson, Women in Stuart England and America, 8; Westerkamp, Women and Religion in Early America, 15; Kathleen M. Brown, Good Wives, Nasty Wenches, and Anxious Patriarchs: Gender, Race, and Power in Colonial Virginia (Chapel Hill: University of North Carolina Press, 1996), 15; Patricia Crawford, Women and Religion in England, 1500-1720 (London: Routledge, 1996), 6.

${ }^{55}$ The name "Halfway Covenant" did not come into use until the 1760 s during a reopened debate over qualifications for baptism. Although the term is anachronistic, it has come to be used as convenient shorthand to describe Proposition Five of the 1662 synod, the extension of baptism. See Pope, Half-Way Covenant, $8 \mathrm{n} 2$. 
church"- baptized but thus far unregenerate adults—from the requirement of confession for admission to full membership, but this raised a difficult question: If these "children" had been members under their parents' covenants as infants, but were not counted as full members in adulthood without a profession of saving grace, at what point did they cease to be saints? Puritan doctrines of predestination meant that only God could grant salvation and that there was no intermediary status between salvation and damnation. If baptized children did not become members in full communion, did this mean their membership--and by implication, their salvation—could be revoked? And, if the membership of the children of the church was in question, what should be done about their children—did the covenant extend to them? Could the children of the "children of the church" be baptized? If the third generation did not qualify for baptism under their parents' baptismal covenant, were they qualified by the promise God made to their grandparents? Who, exactly, was the "seed"?

This conundrum revealed a paradox in Puritan theology; the baptism of infants who could not yet demonstrate saving grace was incompatible with the belief that baptism was a seal of which only the regenerate were the correct subjects. The contradiction between the Puritan denial of grace's inheritability and their practice of infant baptism was not resolvable through simple logic and required some theological gymnastics to justify. ${ }^{56}$ The question of baptism for the founders' grandchildren was

${ }^{56}$ David Kobrin argued that pædobaptism was not inconsistent with Puritan theology because they "denied that all those who were under the covenant of grace were also among the saved." Kobrin, "The Expansion of the Visible Church in New England: 1629-1650," Church History 36 (1967): 191. David D. Hall has suggested that lay Puritans retained some belief in the protective efficacy of baptism, 
broached at synods in 1646 and in 1657 , and both failed to reach a conclusion. ${ }^{57}$

Finally, in 1662, a synod called for this purpose declared that those who had been baptized but had not made confessions of faith could continue, in adulthood, in a halfway status-they would be subject to church discipline and could seek baptism for their children by "owning the covenant," but these halfway members could not vote in church affairs and could not participate in the Lord's Supper. Owning the covenant entailed a public demonstration of doctrinal knowledge and a promise to adhere to it, but stopped short of a full, personal confession. ${ }^{58}$

Examinations of seventeenth-century Congregational churches typically identify the Halfway Covenant as a turning point, after which there were three levels or categories of membership: full communicants, baptized children, and halfway members. Edmund S. Morgan and Robert Pope both argued that the synod created a new kind of membership with modified privileges. David D. Hall expanded on these divisions, describing a "patchwork of membership categories" that included full members, adults who had been baptized but who had not moved into full membership, adults who had not been baptized but participated in "covenant renewals," and

but that does not explain why the ministers and theologians also supported the practice. See Hall, Worlds of Wonder, 153.

57 "The Cambridge Synod and Platform, 1646-1648," in Walker, Creeds and Platforms, 157237; “The Decisions of 1657 and 1662," in Walker, Creeds and Platforms, 288-300. The Baptists untwisted this logical pretzel by forgoing infant baptism altogether.

58 "Result of the Synod of 1662," in Walker, Creeds and Platforms, 301-339; Miller, Colony to Province, 115-116; Pope, Half-Way Covenant, 38. The practice of "owning the covenant" morphed into a collective "covenant renewal" ceremony by the turn of the eighteenth century; see Miller, Colony to Province, 116; and Foster, The Long Argument, 223-227. For a full analysis of the adoption and implementation of the Halfway Covenant, see Pope, Half-Way Covenant. For a gendered analysis, see Brown and Hall, "Family Strategies." 
children. ${ }^{59}$ None of these delineations, however, acknowledged that full membership did not convey universal privileges. They fail to note the modified membership that had been the only type available to female church members all along.

Both halfway members and women in full communion were excluded from participation in church government, though only halfway members were barred from participation in the Supper. In terms of personal piety and public perception, voting had less import than the sacraments, but in practical terms disenfranchisement of women left them officially powerless to direct the affairs of the church, including doctrine and practice, discipline, election of officers, and the admission of new members. Male halfway members retained the option to join in full communion and embrace both the sacrament and the vote, but women's status as subordinate saints was the fullest level of participation they could achieve. While the spiritual benefits of church membership were open to all, women were not allowed participation in the governance of the church or in civic affairs that was the rightful privilege of men who had achieved the same status. Women received what amounted to a kind of halfway status only after undergoing the arduous process of examination and confession. The privileges of governance, decision-making, and voting were not conferred upon all visible saints, but only upon those who had formally joined the covenant and were

${ }^{59}$ Ross W. Beales, Jr., "The Half-Way Covenant and Religious Scrupulosity: The First Church of Dorchester, Massachusetts, as a Test Case," William and Mary Quarterly 31 (1974): 466; Morgan, Visible Saints, 131-132; Pope, Half-Way Covenant, 7; David D. Hall, The Faithful Shepherd: A History of the New England Ministry in the Seventeenth Century (Chapel Hill: University of North Carolina Press, 1972), 204-205. 
male. ${ }^{60}$ These limitations seem as though they could have left women powerless and voiceless in their churches, but women who achieved sainthood could and did find ways to overcome these barriers while still acting within the confines of the gendered hierarchy. Though they could not transcend the halfway status conferred on them as women, they could use their membership and their relationships with men as leverage to shape their experience within the church and to find meaning in the practice of their faith.

\section{"her Soul bound up in the Bundle of Life" The Feminized Congregation}

Considering church membership through a gendered lens reveals the interaction between the English hierarchical system and Puritan theology. This rigorously defined church system, with its firm boundaries around participation, was modified and negotiated to make the Puritans' redefined religious community conform to the social structure they already knew. New Englanders' patriarchal world view constricted women's official participation in the public life of the church, but women's lived experience did not necessarily conform to official prescriptions. Women's dominance on the membership rolls indicates that they were able to find meaning within an institution that seems to have subjugated them.

${ }^{60}$ Robert Pope asserted that the "power of the churches was vested in the congregation" and that "visible saints alone could participate fully," and Michael McGiffert described the admission of new church members in which "enfolded saints...continue to reenact the ritual time after time, year after year, choosing others in God's name." These statements reflect only the experiences of male saints, however, since only covenanted men could "participate fully" and "choose others in God's name." Pope, Half-Way Covenant, 3-4; McGiffert, God's Plot, 145. 
Janet Wilson James has pointed to "two constants" in American women's religious history: "women usually outnumber the men" and "men usually exercise the authority." This holds true in New England Puritanism, where men clearly held the reins of official power despite women's numerical majority in membership. ${ }^{61}$ Explanations for women's attraction to the church in New England have focused around three general themes: First, that women were more pious because of their role as mothers; second, that Puritan definitions of piety were distinctly feminine and therefore women were able to more easily reconcile the role of repentant sinner with their subordinate roles in the world; and third, that Puritanism's assertion of individual salvation provided women with an opportunity for public power despite the limitations their gender imposed. ${ }^{62}$

Motherhood could have contributed to women's piety by focusing their attention on their own mortality and by creating concern for the spiritual welfare of their children. Childbirth was a dangerous prospect in the seventeenth century, and while child mortality was lower in New England than it had been in old England, the

${ }^{61}$ Janet Wilson James, "Women in American Religious History: An Overview," in Women in American Religion, ed. Janet Wilson James (Philadelphia: University of Pennsylvania Press, 1980), 1. Mary Maples Dunn found that the demographic disparity began to appear as early as the 1640 s and that after 1660 women constituted a majority of admissions throughout Massachusetts. Dunn, "Saints and Sisters," 590-591. Gerald F. Moran found the same to be true in Milford, Connecticut. Moran, "Religious Renewal, Puritan Tribalism, and the Family in Seventeenth-Century Milford, Connecticut," William and Mary Quarterly 36 (1979): 246. David D. Hall has suggested that the statistical imbalance resulted not from more women joining, but fewer men. He argued that the examination and confession required for full membership were "more terrifying (or perhaps more humiliating)" for men than for women, particularly because women avoided the most public aspect of the ritual by having their confessions read rather than making them personally. Hall, Faithful Shepherd, 205. This hypothesis could be tested by investigating whether men's proportion of admissions increased after churches began allowing them to make private confessions.

${ }^{62}$ A good overview is Porterfield, "Women's Attraction to Puritanism.” 
survival of both mothers and children were less than certain. Facing the possibility of death in childbirth may have turned women's thoughts more often to the state of their souls. If she survived the birth, a woman turned to the task of raising the child in piety and good discipline; according to this argument, mothers were motivated to join churches, in part, so that their children would have the benefit of baptism. ${ }^{63}$ This is borne out by Robert Pope's finding that women were more likely than men to take advantage of the Halfway Covenant in the churches he surveyed. Still, this line of reasoning is not entirely satisfying. In Puritan New England, fathers were considered the spiritual heads of their households and as such would have also had investment in their children's spiritual welfare. ${ }^{64}$ Certainly women were defined in Puritan society by their status as mothers, and a sense of maternal duty may have contributed to women's desire to become church members. However, concern for children's welfare

${ }^{63}$ Ulrich, "Vertuous Women Found," 31-32; Brown and Hall, "Family Strategies," 54; Pope, Half-Way Covenant, 213, 218, 225. This assertion is somewhat supported by Edmund Morgan's finding that "the urge to perpetuate pure religion among their children" was one of the most important motivations for the Great Migration. Morgan, Puritan Family, 168. Brown and Hall note that the "coincidence of marriage, pregnancy, and birth with decisions to renew the covenant or become a church member" coupled with women's predominance in membership rolls "underscores the powerful nexus between family formation and church membership." Brown and Hall, "Family Strategies," 58.

${ }^{64}$ Pope, Half-Way Covenant, 213-218. Laurel Thatcher Ulrich's examination of John Winthrop's journal, for instance, suggests that "the Boston congregation had deviated from English custom by having the father rather than the midwife or a godparent hold the child during baptism," which may have implied "a symbolic shift from communal to familial responsibility for the child and perhaps as well from female to male nurture." Ulrich, "John Winthrop's City of Women," 36. John Cotton reported that "The Father presenteth his owne childe to baptism." Cotton, Way of the Churches, 68. Fathers also took responsibility for catechizing children; see the confession of Martha Collins in Selement and Woolley, eds., Thomas Shepard's "Confessions," 130. While Brown and Hall note that it was "women, in the main, who brought children to the sacrament of baptism" and argue that this "bespeaks the assumption among these participants that mothers were especially responsible for the spiritual welfare of their children," it is possible that more women than men presented their children because women were more likely to be members. Brown and Hall do not provide an analysis of this phenomenon that takes the parents' membership status into account. They do, however, acknowledge that fathers would have had an equal concern for children's spiritual welfare. Brown and Hall, "Family Strategies," 53-54. 
was not solely the responsibility of women and should also have motivated men to join, so this cannot fully explain the discrepancy. Neither can the association of sainthood with feminine imagery and values fully explain women's disproportionate membership numbers. ${ }^{65}$ While there was some association between the qualities of the ideal woman and the ideal believer, qualities like "meekness" and "submissiveness" were not totally feminized concepts in the seventeenth century and would not necessarily have struck the Puritans as references to particularly female traits. $^{66}$

Women were limited in their access to official modes of power in all aspects of Puritan society, but the church offered them a means to indirect power through its emphasis on individual salvation. Several works have suggested that it was this access to institutional power which led women to join churches in disproportionate numbers.

Charles Lloyd Cohen reasoned that it was this sense of spiritual equality that led women to join despite the gendered inequalities of church membership. ${ }^{67}$ Mary Maples Dunn argued that female piety served a purpose for society in a way that male

${ }^{65}$ See, for example, Margaret W. Masson, "The Typology of the Female as a Model for the Regenerate: Puritan Preaching, 1690-1730," Signs 2 (1976): 314-315; Porterfield, “Women's Attraction to Puritanism," 202.

${ }^{66}$ Ulrich, "Vertuous Women Found," 28.

${ }^{67}$ Cohen, God's Caress, 240-241. Cohen's argument dovetails with Lyle Koehler's assertion that a message of submission was ubiquitously transmitted to Puritan women; using Koehler's analysis, it is possible to argue that joining the church was an expression of submission that Puritan women were socialized to perform. Koehler, Search for Power, 22. While Koehler made an important contribution to the study of Puritan women, Ulrich was unfortunately correct in her assessment that his work "is marred by a curiously polemical style and by what sometimes appears as deliberate distortion of evidence." Laurel Thatcher Ulrich, Good Wives: Image and Reality in the Lives of Women in Northern New England, 1650-1750 (New York: Vintage, 1991), 281. 
piety did not, and assigning different goals to men and women led to a decline in male piety while women's increased because religion became less connected to men's social goals and more connected to women's. By the last half of the seventeenth century, women were more closely associated with maintaining the faith and the Puritan mission, and this set of gendered expectations pushed women into the church at the same time they made piety less important for men. ${ }^{68}$ Laurel Thatcher Ulrich and Amanda Porterfield have argued that the church's emphasis on spiritual equality provided women with access to alternate routes to power by giving them access to a public institution. Despite limitations on their official exercise of power-denial of the vote and of leadership roles-women were able to rely on private, indirect influence to shape their lived experience within the church. ${ }^{69}$

The increasing proportion of women on the membership rolls likely resulted from a combination of these factors. Though women also had access to civil courts for the resolution of disputes, the church was the only social institution in which women were not just occasional participants or observers, but were members and insiders involved in its daily operation. The church's emphasis on both spiritual equality and personal piety helped women find meaning for themselves as believers. Whatever the reasons, the higher proportion of female church members meant that the

${ }^{68}$ Mary Maples Dunn, "Saints and Sisters: Congregational and Quaker Women in the Early Colonial Period," in "Women and Religion," special issue, American Quarterly 30 (1978): 592-594. Dunn's theory, while appealing, lacks substantive primary source evidence. More research is certainly warranted to determine if her argument can be a viable explanation.

${ }^{69}$ Ulrich, Good Wives, 216-219; Porterfield, "Women's Attraction to Puritanism," 199. 
church was being shaped and led by a small fraction of those who walked through its doors every week.

Though women were a numerical majority in New England's Puritan churches, those churches remained male-dominated institutions. The clergy and elders were all men, and they were chosen by the votes of only the male saints. Those clergymen defined the doctrine, wrote the sermons, and administered the sacraments. Women's admission to membership was contingent upon the approval of both the male elders and the male portion of the membership, and women were subject to discipline that was defined and doled out by men. Women were able to forge their own lived experience to a degree, however, by studying scripture, participating in discussions about doctrine, sharing in the sacraments, and engaging in private prayer. Though they had no formal voice in church government, their status as saints gave them indirect access to institutional power because their status as church members allowed them to influence male authority figures in private meetings and conversations. While in many ways women experienced church membership very differently than did men, in other ways sainthood was a genderless status. Women's modified church membership reflected the Puritans' hierarchical world view and as such did not contradict their belief in individual spiritual autonomy before God. On the surface, the contradictions between women's status as saints and their status as women seem to have been resolved seamlessly, but the tensions were real and had real consequences. 
Women were subject to competing covenants-in their churches and in their marriages - and were subordinate in all of them. Yet within these covenants, and particularly in the undefined spaces between them, women were able to access a public role. The delicate balance women must have struck between assertiveness and submission could not have been inconsequential to their everyday experiences as New Englanders and as church members. In a faith that privileged the voices of the laity, those who constituted a majority of church members were denied access to governance. These women were not ignorant of the principles on which their churches were founded; they read, heard, and discussed these ideas and so they could not have been completely unaware of the discrepancy. Even if the Puritan world view made gender a natural, rather than constructed, distinction, both men and women were regularly reminded of gendered exceptions to saints' responsibilities and privileges every time they took their seats in the meetinghouse. Although Puritan piety encouraged rigorous introspection, this faith was as much social experience as it was personal. Puritans granted the laity not only a right to engage with a community of saints through knowledge, worship, and discipline, but also demanded of them that they participate in the constant maintenance of the errand. The preservation of public faith in the churches through enforcement and refinement of doctrine, through the imposition of discipline on wayward members, and through scrutiny of their fellows, was a public responsibility. These public acts of faith were the purview of all visible saints--of men, who were sanctioned to speak and vote, but also of women, who were 
equally responsible as saints but who were not equally equipped to act in the service of these goals.

The rule that women be silent in church was very specific and very technical and therefore allowed avenues of expression and influence that transcended the injunction of silence. It was not women's speech that was threatening to the church order, but the authority that would be implied by allowing them to vocalize their opinions in situations where they might influence, teach, or lead men. Women could not speak aloud before mixed audiences in anything other than a submissive stance, and they could not vote, but they could and did exercise influence in private conversations with men or women, and they could speak through written communications that could be shared with the entire congregation. ${ }^{70}$ Though women could not speak, they were not silenced.

Church membership was seen, at least prior to the Halfway Covenant, as a dichotomous condition: Someone either was a church member or was not. There is no evidence that women were considered to be anything less than full members, but their practical experience of that status was fundamentally different from that of their male counterparts. Women in New England's churches experienced a modified form of membership that fused the Puritan belief in individual sainthood with a patriarchal social structure. Puritan society was structured around a set of interlocking hierarchical relationships, and within those relationships women were always

${ }^{70}$ Women most commonly used these written communications to give their confessions of faith and to request dismission to another congregation, but they may also have used this method when confronted with disciplinary action. See Kamensky, Governing the Tongue, 85 . 
subordinate to men. When viewed in isolation, the various restrictions placed on women's activities can seem to be of little consequence, but examining the limitations in their entirety reveals that women's church membership was fundamentally different than that of their fathers, husbands, brothers, and sons.

The absence of female voices in seventeenth-century records means that we cannot know whether the women seated together on their own side of the meetinghouse felt frustration with these restrictions or wished for more vocal roles. We can only investigate how they behaved when these restrictions were put to the test. The founding of Third Church illustrates the interplay between official restriction and informal power. After the dissenting men left their covenant and formed a new church, the wives' five-year fight to join their husbands was shaped by their gender. While these women lacked the power to vote and speak publicly, they were able to pursue their desired dismissions without violating the boundaries set around women's behavior in the church. When this group of women found themselves caught between a church they wished to leave and one they wished to join, they negotiated their way through their conflict with male authorities without speaking publicly in service of their cause and without casting any votes to determine their fates. The differences between these women's actions and their husbands' show how theoretical restrictions on women's behavior in Puritan churches manifested in practice. The wives' ability to advocate for themselves as church members was mitigated by their peculiar status as both individual saints and social subordinates. 


\section{Chapter Two}

\section{"We cannot see our way cleare to so act with yourselves" The Founding of Third Church, Boston}

Choosing a minister was one of the most important acts of a Puritan congregation. Although churches were theoretically governed by their members, in practice it was the teachers and pastors who were largely responsible for shaping practice. These men also administered sacraments and preached sermons, both of which were means of bringing saints to a realization of their state of grace. John Cotton knew that choosing a minister was a luxury the parish system in England had not afforded, but he also understood that the choice could cause conflict among church members. In the 1650 s, to demonstrate how the voluntary gathered church was superior to the parish system, Cotton described a hypothetical situation wherein a minister died and "another one called into his place and Office by the generality of the Church, who may be unsuitable to this or that Brother." In that case, Cotton said, it would be better to grant that church member dismission rather than ask him to "submit to the choice of the Church" or ask the church to "suspend their choice upon the Negative vote of any one Brother." If the "dissenting Brother" should seek a letter of dismission, the church would be "bound to yield unto his equall and just desire, that so they may part in a loving and brotherly manner."1 Just fifteen years after his death, the very church that Cotton had led was split over the choice of a minister to fill its pulpit and the elders ignored his prescient advice. There were other contentious

${ }^{1}$ John Cotton, Certain Queries Tending to Accommodation and Communion (London: M. S. for John Allen, 1654), Wing C6416, p. 19. This pamphlet was published in 1654, two years after Cotton's death, and so it is unclear exactly when it was written. 
schisms in New England, but none so dramatically affected the entire colony as this one. ${ }^{2}$ First Church's effort to hold a group of dissenters in their covenant engulfed the colony in conflict and led to the formation of a new church in Boston.

Though it was not the first church established by Puritan immigrants in New England, geography and politics put Boston's First Church at the center of New England's early history. Located in New England's largest town and most significant port, it was the only church in Boston for the colony's first two decades. Even after Second Church had been established in the north end of the peninsula, First continued to be the church of magistrates and merchants, and many of Boston's (and therefore the colony's) most distinguished inhabitants could be found in its meetinghouse for lectures and Sabbath services. ${ }^{3}$ Boston's ministers had prominent voices in all the debates of the seventeenth century; their proximity to the center of political power gave them opportunities to influence civic policy, and their access to the printing presses in both New England and London gave them an effective audience much larger than that which filled their pews. First Church's early years had been disrupted by the Antinomian controversy, but it had since enjoyed years of relative stability and moderation under the leadership of ministers John Norton and John Wilson. In 1667

${ }^{2}$ A similar situation had developed in Connecticut when a group of dissenters broke away from the Hartford church in 1659, and another occured when some members of Salem First attempted to form a church at Lynn. See Sylvester Judd, History of Hadley (Springfield, MA: H. R. Huntting \& Company, 1905), 3-7; and Alonzo Lewis and James R. Newhall, History of Lynn, Essex County, Massachusetts: Including Lynnfield, Saugus, Swampscot, and Nahant (Boston: John L. Shorey, 1865), 261.

${ }^{3}$ Mark A. Peterson, The Price of Redemption: The Spiritual Economy of Puritan New England (Stanford, CA: Stanford University Press, 1997), 25. 
the church found their pulpit vacant for the first time after the two ministers died within just a few years of each other, and First Church chose to call not another moderate but New England's most vocal opponent of the Halfway Covenant, John Davenport of New Haven.

First Church had at least nominally adopted Halfway principles as early as 1657 , when they voted to exercise discipline over baptized non-communicants as though they were members, and the ministers had begun to gauge interest in "owning the covenant" among the children of the church. The synod result had not been implemented by the church, however, when its moderate voices in the pulpit were lost. Several prominent members of the church opposed the practice and they were likely instrumental in choosing Davenport for the church's ministry. ${ }^{4}$ This choice was a clear signal that the church would reverse course on the extension of baptism, which Norton and Wilson had been inching toward in the years before their deaths.

Davenport believed the Halfway measures to be a dangerous innovation that threatened the purity of churches; he argued that baptism was not, in fact, a seal of the

${ }^{4}$ Richard D. Pierce, ed., The Records of the First Church in Boston 1630-1868, Publications of the Colonial Society of Massachusetts 39 (Boston: Colonial Society of Massachusetts, 1961) [hereafter First Church Records], xxx-xxxi, 55-56; John Hull, Memoir and Diaries of John Hill [Hull], Mint-master and Treasurer of the Colony of Massachusetts Bay (1857; repr. New York: AMS Press, 1982) [hereafter Hull Diary], 198; Williston Walker, The Creeds and Platforms of Congregationalism (1893; Cleveland, OH: United Church Press, 1991), 265; Robert G. Pope, The Half-Way Covenant: Church Membership in Puritan New England (1969; Eugene, OR: Wipf and Stock, 2002), 35-37, 153. Extant records do not indicate the reasoning behind Davenport's call or who may have instigated it. The first pages of the Third Church Narrative are missing, and First Church Records and John Hull's diary are both silent on this aspect of the controversy. Magistrates John Leverett and Edward Tyng, deputy Thomas Clarke, and Anthony Stoddard were vocal opponents of the synod. See Pope, Half-Way Covenant, 35-36; and Stephen Foster, The Long Argument: English Puritanism and the Shaping of New England Culture, 1570-1700 (Chapel Hill: University of North Carolina Press, 1991), 203. These men also likely led the charge against the dissenters, since the church lacked ministerial authority during the first year of the crisis and was under the sole authority of the elders. 
child's "compleat and immediate" membership but was merely a seal of the parent's covenant, and that there should be no degree of immediate membership available without a full accounting of one's conversion experience. Knowledge of doctrine was simply not enough. Though he engaged in a vigorous pamphlet war over the Halfway result, Davenport had refused to attend the synod because he was also a fierce advocate for congregational independence; he not only opposed this particular synod result, but also rejected the premise of any synodical influence over individual congregations. His call to the pulpit at First Church may indicate that a good portion of the membership was opposed to the baptismal innovation and saw the vacancy as an opportunity to retreat from it. Davenport's appointment changed First Church's trajectory on baptism for sixty years; they did not fully implement the Halfway Covenant until $1731 .^{5}$

John Davenport was not the church's first choice for their pulpit. James Allen had been suggested as an assistant to Norton and Wilson as early as 1662, but First Church was fully supplied with two teaching officers at the time and so the church declined to call a third. Now, with the pulpit completely vacant, it was agreed that although Allen occasionally preached in the church he was "unmeet to lead and rule

${ }^{5}$ John Davenport, Another Essay For Investigation of the Truth.... (Cambridge, MA: Samuel Green and Marmaduke Johnson, 1663), Wing D356, p. 42, 52-64; E. Brooks Holifield, The Covenant Sealed: The Development of Puritan Sacramental Theology in Old and New England, 1570-1720 (New Haven, CT: Yale University Press, 1974), 174-182; Pope, Half-Way Covenant, 85, 89-90; Cotton Mather, Magnalia Christi Americana (Hartford, CT: Silas Andrus and Son, 1855), 2:312; Pierce, "Historical Introduction," First Church Records, xxxiii; First Church Records, 161-162. This again put First Church in opposition to prevailing winds, since opinion during the Great Awakening was turning among the New Lights toward stricter requirements for baptism. See Pope, Half-Way Covenant, 276-277. 
our congregation alone, and therefore another must be first voted to guide and rule him." On the death of Norton in 1663, the church reached out to John Owen in England, but after three years of correspondence he was unable to accept the call. ${ }^{6}$ When Wilson died in 1667 and the church had still not filled the vacancy, they turned to the aging teacher at New Haven.

John Davenport was nearing seventy years old when he was called to First Church's pulpit. He had been one of the original subscribers to the Massachusetts Bay Company charter and emigrated in 1637 after he had been deprived of his pulpit in England for nonconformity and spent some years in Laudian exile in Holland. Davenport had been a close colleague of John Cotton, who had encouraged the young minister to join him in Boston. ${ }^{7}$ Davenport remained with Cotton in Boston for only a short time before moving on, helping settle the struggling colony of New Haven with merchant Theophilus Eaton. Davenport remained in the pulpit at New Haven for forty years and there had helped craft the "strictest Bible commonwealth" in New England

${ }^{6}$ Peterson, Price of Redemption, 27. See also Richard C. Simmons, "The Founding of Third Church in Boston," William and Mary Quarterly 26 (1969): 242. Some sources claim that John Allen lost his pulpit after the Act of Uniformity, but Hill disputes that assertion. See Hamilton Andrews Hill, History of the Old South Church (Third Church) Boston, 1669-1884 (Boston: Houghton, Mifflin and Company, 1890) [hereafter History of the Old South], 5. "Reasons of Dissent," 30 September 1667, in Third Church Narrative, 17; First Church Records, 59; Hill, History of the Old South, 4-5; Larzer Ziff, Puritanism in America: New Culture in a New World (New York: Viking, 1973), 184; Thomas Hutchinson, The History of the Colony and Province of Massachusetts-Bay, ed. Lawrence Shaw Mayo (1764; Cambridge, MA: Harvard University Press, 1936), 1:193-194; John Gorham Palfrey, History of New England during the Stuart Dynasty (Boston: Little, Brown, 1882), 3:83.

${ }^{7}$ Mather, Magnalia, 1:325; Palfrey, History of New England, 1:528. Davenport participated in the Synod of 1637 and in Anne Hutchinson's trial before moving on to New Haven. "A Report of the Trial of Anne Hutchinson before the Church in Boston," in David D. Hall, ed., The Antinomian Controversy, 1636-1638: A Documentary History, $2^{\text {nd }}$ ed. (Durham, NC: Duke University Press, 1990), 349-388. Cotton and Davenport were so closely associated in life that after Davenport's death he was interred in Cotton's grave. 
before he was called back to Boston. Davenport's association with John Cotton and his status as one of the last surviving founding ministers may have influenced First Church's decision to call him; he was their last link to the legacy of the founders at a time when the baptismal innovation, royal interference, and incursions by Quakers and Baptists seemed to threaten the future of the New England Way. ${ }^{8}$ Davenport's decision to accept the call was likewise influenced by both religious and political factors. The First Church pulpit was a more effective platform for him to fight against the Halfway innovation, and he was disheartened by the absorption of New Haven into the larger (and less strict) colony of Connecticut.

When the church proposed calling Davenport to fill the vacancy the decision was met with discontent by a small but significant minority of First Church members. Though the initial dissent may have come from as many as forty men, in September 1667 twenty-eight members of First Church petitioned the elders to postpone calling Davenport until the members had more opportunity to discuss the choice; if, after a "free and full consultacion" they were unable to agree, the dissenters would "acquiesce in the advice of a Councill of Elders and Messengers of Churches mutually

${ }^{8}$ Pope, Half-Way Covenant, 22; Pierce, "Historical Introduction," First Church Records, xxxiii; Isabel M. Calder, "John Cotton and the New Haven Colony," New England Quarterly 3 (1930): 82-94; Mather, Magnalia, 1:328-329; Pope, Half-Way Covenant, 10; Foster, The Long Argument, 177; James F. Cooper, Jr., Tenacious of Their Liberties: The Congregationalists in Colonial Massachusetts (Oxford, UK: Oxford University Press, 1999), 89-92; Ziff, Puritanism in America, 184; Janice Knight, Orthodoxies in Massachusetts: Rereading American Puritanism (Cambridge, MA: Harvard University Press, 1994), 29-30, 186; E. Brooks Holifield, "On Toleration in Massachusetts," Church History 38 (1969): 188-200; Simmons, "The Founding of the Third Church," 241-252. 
to be chosen." When the elders ignored this request and persisted in asking New Haven to dismiss Davenport to them, the minority (or "dissenting brethren") presented the elders with a document outlining the reasons for their opposition. The initial disagreement over calling Davenport to the ministry almost certainly centered on his opposition to the Halfway Covenant, but the concerns expressed in this letter were largely procedural: Davenport had not yet been properly dismissed from New Haven, they claimed, and the call had been "sudden" and did not provide an opportunity for "free debate." The dissenters did briefly take issue with the church's reversal of course on the Halfway Covenant, arguing that the church had already voted to adopt its principles and had at that time given ample opportunity for hesitant members to express their concerns. Turning their backs on the synod result, the dissenters claimed, meant that First Church was "plucking downe" what their founders had built and "in stead of following their faith, should now divert from it."10 The elders waited nine months to reply to the dissenters' objections.

Meanwhile, despite the objections and the lack of unanimity in First Church, Davenport agreed to come to Boston to "finde out the minde of God." 11 He indicated

9 "A Second Letter of Mr. Davenports that came per Captaine Clarke," in Third Church Narrative, 21; "Humble Request of the Dissenting Brethren," in Third Church Narrative, 13-14.

10 "Reasons of Dissent," in Third Church Narrative, 16-17.

11 "A Second Letter of Mr. Davenport," in Third Church Narrative, 21; Hull Diary, 226. First Church had transitioned from requiring unanimity to a "more easily controlled" majority rule in the 1640s. See Darrett B. Rutman, Winthrop's Boston: A Portrait of a Puritan Town, 1630-1649 (Chapel Hill: University of North Carolina, 1965), 265. See also Cooper, Tenacious of Their Liberties, 111; and Thomas Lechford, Plain Dealing: or, Newes from New-England (London: W. E. and I. G. for Nath. Butter, 1642), Wing L810, p. 14. 
that he would return to New Haven if he was not satisfied, but it appears that from the beginning he intended to stay in Boston, and in fact he never again set foot in New Haven. Upon his arrival in Boston in May 1668, about twenty of the dissenting brethren went with the church's blessing to meet with Davenport and "informe him of the true state of matters," but when they arrived he was "unwilling to treat with them, without the presence of some of the other Brethren." He eventually agreed to hear them out but gave no response until the following lecture day, when he used the pulpit to criticize the dissenters for their refusal to yield. The face-off between Davenport and the dissenting brethren soon reached a critical point, with the dissenters considering departure and Davenport suggesting that he would not agree to take the call unless the dissenters would "sit downe silent" and drop their opposition. ${ }^{12}$

Some members of the majority called for the dissenters to be censured, but Elder James Penn refused to grant it and instead called for a council. The council called by First Church met in Boston at the beginning of August 1668 and concluded that the ideal of "Brotherly love" was not "attaineable by continuance in one Church Body." They noted that the population of Boston now far exceeded the capacity of its two churches, which gave many people an excuse to absent themselves and this "doe make it an opportunity of great profaneness." The council therefore recommended that the dissenters be dismissed with the "love and prayers" of First Church, that they be allowed to set up a new church in Boston, and that they be permitted to seek

\footnotetext{
${ }^{12}$ Third Church Narrative, 23-24.
} 
communion in either First or any other church until their new congregation could be established. Elder Penn read the result to the congregation of First Church and declared with sadness that the dismissions seemed to be "the will of the Lord." Some members were concerned that the dissenters could remain in First indefinitely by this decree, but the dissenters assured them that "if the Church would give them their dismission they would accept of it." 13 They presented their request for dismission two days later.

First Church held a meeting to discuss the dissenters' request on August 10. At this meeting, several First Church members asked the dissenters to leave the meetinghouse. The dissenters agreed to do so only if the church limited their discussion to the request; they explained that "if the Church had busines to transact that concerned all the Church they durst not absent themselves." After the dissenting men departed, their wives were "desired by the Elder and ordered to with draw." With the dissenters and their wives outside the meetinghouse, the church immediately reneged on its promise and gave Davenport an official call to the pulpit. Davenport revealed that he had anticipated the call even before he was summoned to Boston and had in fact been courted by members of First Church through "severall letters" that had "passed in order there unto the yeare before." 14 First Church sent a letter to New

13 "Result of the first Councill," in Third Church Narrative, 26-27; Records of the First Church at Dorchester in New England 1636-1734 (Boston: George H. Ellis, 1891) [hereafter Dorchester Church Records], 54.

${ }^{14}$ Third Church Narrative, 28-29. 
Haven formally requesting that they dismiss their minister so that he could be installed in Boston's pulpit. The church did not vote on the dismissions, however.

The question was once again raised at a church meeting on October 9 while the dissenters waited next door; afterward, messengers from the church told the dissenting brethren that First still "did earnestly desire their reuniting" and that they would not consider the motion for dismission; the messengers from First Church explained that this was "not a season" to discuss the separation since they were not yet ready to ordain Davenport. After a letter of reply from New Haven that seemed to grant Davenport's dismission was received and read to the church later in October, however, First Church began to make preparations for his ordination. On the news that Davenport could soon be ordained, the dissenting brethren made more urgent efforts to secure release from their covenants with First. They failed to obtain their release before Davenport was admitted into membership and given "a full and authorative call," and so they sent a letter to four neighboring churches requesting that the previous council be reconvened. These messengers met on November 23 and forged an agreement whereby the dissenters would let Davenport's ordination "passe without publique opposition" if their silence would not be construed as consent, and Davenport was ordained on December 10, $1668 .^{15}$

One month after Davenport's ordination, he used a sermon to declare that if the dissenters were to take the Supper it would "actually and really demonstrate their acceptance of the teaching officers, as well as if they had consented from the

${ }^{15}$ Third Church Narrative, 32, 36-37; Hull Diary, 228; Dorchester Church Records, 56. 
beginning." The dissenters saw that they were in a no-win situation: "if they did partake they [First Church] would never give them [the dissenters] their dismission, but tell them they had lost their case by their owne consent, and if they did not partake, they would improve it against them in order to censure." On the Saturday afternoon before the sacrament was to be offered, the dissenters delivered a letter to the elders explaining that they could not take communion with the church under the conditions Davenport had imposed. When the sacrament was administered, all of the dissenters withdrew except for those who served as deacons; these men were required to help administer the Supper, and they performed their duty at the table so that they would not be censured, but they did not partake. The church later discharged the deacons of their offices for refusing the Supper on these grounds but once again did not censure any of the dissenters, and Davenport seems to have backed off his earlier ultimatum because they all "sate down with the Church at the Lords table" at the next administration. ${ }^{16}$

The dissenters submitted another letter to the church in February requesting four possible actions: that the church grant their dismissions; that the church grant their dismissions in several months, after a new meetinghouse had been built; that the church recall the council or allow the dissenters to do so; or that the church dismiss them to another congregation. All of these were denied. First Church held another meeting in March 1668/69 to discuss the dissenters' request for dismission. The

\footnotetext{
${ }^{16}$ Third Church Narrative, $46-49$.
} 
dissenters asked again for another council but were denied. A vote was put to the church about whether to grant the dismissions, and "it was answered in the Negative: unanimously." The church also bowed to the Elders' opinion that "to grant a Councill tends to overthrow the Congregationall way," that "there was no releife for a greived Brother or Brethren in a church unless the Church will relieve them untill the day of judgement and That the church itselfe is the sole and alone Judge." 17

With the church so clearly and adamantly opposed to a council, the dissenters decided to call a council themselves. The men sent a request to "severall churches" asking that they consider the case, explaining their predicament in being unable to secure dismissions despite the previous council result. Rather than a breach of the Congregational Way, as First Church saw it, the dissenters viewed councils of neighboring churches as "the onely next refuge in order left us by christ in his word."18 The ministers of the churches at Dedham and Roxbury, John Allin and John Elliot, drafted a letter in support of the dissenters' cause. Allin and Elliot, who had been members of the first council, expressed serious concern about the situation in Boston, noting that a rejection of councils would mean that churches would have "noe meanes to heale breaches and other Evills in our churches." They argued that it was time for First Church's neighbors to "perswad the Elders of Boston to graunt their dismission" and that this would be in the best interests not only of the dissenters but also of First Church and the congregational system. They encouraged representatives

${ }^{17}$ Third Church Narrative, 49, 52-53; First Church Records, 62. 53.

${ }^{18}$ Dissenting brethren to neighboring churches, 31 March 1669, in Third Church Narrative, 
from the churches to meet them in Charlestown and "prepare our thoughts for a conference with the Elders of Boston." 19

It is unclear whether First Church was aware that these letters had been sent, but a few days later a meeting was hastily called by Elder Penn, purportedly so that the dissenters' "offences might be removed soe as that there might be a comfortable sitting downe" when the Lord's Supper was next administered. At what must have been a raucous meeting, Joseph Davis and John Hull were "singled out" among the dissenters and accused of "haveing layed a false charge upon the Elders." When a protracted debate failed to reach a conclusion, Elder Penn then accused the dissenters of offending the church by "absenting themselves" from the Lord's Supper and then later taking the sacrament without "giving satisfaction" to the church. Two other dissenters, Edward Rawson and Thomas Savage, jumped to defend all the dissenters' actions, arguing that they had given written explanations for their absence in advance and had tried to restore some peace in the church despite their disagreements by taking the Supper afterward. A member of the majority then accused all the dissenters of being "guilty of scisme and making divisions in the Church" and argued that "it was the Church duty, to lay them under censure." He specifically singled out Davis, Rawson, and Hull as the "ring leaders" of the dissent, since the dissenters often held their meetings at these men's houses. The other dissenters then jumped to their feet

\footnotetext{
${ }^{19}$ John Allin and John Elliot to churches at Salem, Linn, and Ipswich, 2 April 1669, in Third
} Church Narrative, 55. 
and denied the charges, asserting that they "were noe ways led by them or any other."20

At this point, Elder Penn tried to defuse the meeting's tensions and suggested that they "might all sit downe at the Lords table together and he could pass all by." Davenport, who seems to have been silent up to this point in the proceedings, rebuffed Penn's suggestion and "declared that he could not sitt downe at the Lords Table with the dissenters, untill they had given him satisfaction"; this was seconded by Anthony Stoddard, among others. The church finally set a meeting for the following week to "charge the dissenters in a better method than they had done," to present their charges against the dissenters in writing and to have formal proceedings "managed" by the elder and judged by the brethren. ${ }^{21}$ A formal censure seemed imminent.

The second council, which had been summoned by the dissenters, met in Boston four days later. The dissenters reasserted their hope that the matter could be settled according to the first council's recommendations; they reiterated their inability to "sit down quietly and submit to the act of the rest" in the call to Davenport and also their belief that they had no hope of "releif but in our application to yourselves as the onely ordinance of God provided in such cases." 22 The council asked that representatives of First Church meet with them, but the elders replied that while they

\footnotetext{
${ }^{20}$ Third Church Narrative, 55-57.

${ }^{21}$ Third Church Narrative, 57.
}

22 Dissenters to the Second Council, 13 April 1669, in Third Church Narrative, 58; Hull Diary, 229; Richard D. Pierce, ed., The Records of the First Church in Salem, Massachusetts 1629-1736 (Salem, MA: Essex Institute, 1974), 119-120; Dorchester Church Records, 58-59. 
would relate any council result to their congregation, they would not agree to a meeting because it would give "offence to the church." The council sent another letter attempting to persuade representatives from First Church to meet with them but was again and more forcefully refused. Davenport and Penn averred that the council was illegitimate and that the disposition of the dissenters was an internal matter that could only be decided by the church itself. ${ }^{23}$

The tension between the autonomy of individual churches and the need to somehow enforce consistency in practice cut to the heart of the congregational system. Certainly, the elders of First Church had a point that the internal affairs of their congregation were not subject to the opinions of their neighbors, since each congregation was individually constituted. However, these independent congregations were also interdependent. They relied on each other to adhere to and practice the principles of the New England Way sufficiently that they could be called upon to help with the establishment of new churches and with ordinations and that their discernment of a member's likely sainthood could be used as evidence for admission. While Davenport believed that there was a relationship between the churches, he believed that only individual congregations could determine practice and discipline inside their own meetinghouse. Davenport's rejection of the Halfway Covenant was based at least in part on his rejection of consociation (interchurch cooperation for the

23 "The Answer of the Elders of the Church of Boston to the Letters of the Churches Messengers," 13 April 1669; "The 2d Councills 2d Letter to the Elders of the Church of Boston," 13 April 1669; "The Answer of the Elders of the Church of Boston to the 2d Letter of the Messengers of the Churches," 13 April 1669; all in Third Church Narrative, 59-60. 
purpose of advising on doctrine and practice) and he continued this rejection in his denunciation of the councils.

The day after Davenport and Penn responded to the council, the church met to consider the dissenters' fate. The council was meeting at the same time in Charlestown and sent messengers to deliver another letter to First Church. This letter, signed by thirty-two male representatives of neighboring churches, pleaded with the church to meet with the council before rendering a decision about the dissenters. ${ }^{24}$ The council messengers, who included Richard Mather and other "Reverend Honoured and aged Gentlemen," hoped to meet with representatives from First Church before the council issued its result, but they found the meetinghouse door locked and waited outside at such length that chairs were brought for them. While they sat outside the locked door of the meetinghouse, church members arrived for the meeting and found themselves locked out as well.

After several hours the letter was eventually taken inside, though not by the council messengers themselves as they had desired, and two votes of the church were required before the letter was read to the congregation. The church voted to "take no notice of it, and laid it by, but proceeded to that which they called the worke of the day." Someone inside the church meeting—possibly Elder Penn-must have taken the dissenters' side because although many had seemed prepared to censure the men,

\footnotetext{
${ }^{24}$ Letter of the $2 \mathrm{~d}$ Councill to the Church of Boston, 14 April 1669, in Third Church Narrative, $61-62$.
} 
this meeting, too, ended without resolution of the dissenters' fate. ${ }^{25}$ After being refused a meeting with the First Church elders, the council representatives returned to their deliberations. Later that day, after returning to his son's home, Richard Mather collapsed and within a week he was dead. Mather was seventy-three, partially blind and nearly deaf, and his final illness was likely caused by a preexisting kidney condition, but the strain of moderating the council may have been more than coincidental. ${ }^{26}$

Mather's illness prevented him from signing the council result that was issued later that day. The council declared that their meeting was appropriate and allowed by the principle of consociation, and that the request by the dissenters for their opinion was "regular and orderly" since they sought advice on the result of a previous council that had been called by the church elder "with the consent of the Brethren." This second council found that the first council's result had been sound, that the dissenters had, "according to the Councills advice, seasonably—earnestly, frequently, and humbly desire[d] the said dismission," and that First Church had never given a reason for ignoring the council result. The second council therefore concluded that First Church was compelled to follow the first council result, to grant the dissenters their dismissions, and to allow them to have communion at any church in order (including First) until their new meetinghouse could be built. The council further declared that

${ }^{25}$ Third Church Narrative, 62-63.

${ }^{26}$ On Richard Mather's death, see Cotton Mather, Magnalia, 1:454-456; Michael G. Hall, The Last American Puritan: The Life of Increase Mather (Middletown, CT: Wesleyan University Press, 1988), 78-81. 
First Church's refusal to grant the dismissions did not abrogate the dissenters' right to have them, and that the first council result gave the dissenters "immunity from censure" in the matter. This second council stated that the establishment of a new church by the dissenters "may seasonably proceed" despite First's objections. ${ }^{27}$

The dissenters then submitted another letter to the church. The dissenters denied that they were "guilty of any open Publike and scandalous offence" that would justify censure, and they asserted that the church's actions against them did not in fact constitute censure. They declared that the church had "disobliged themselves from any other duty unto us, and evacuated that relation which sometimes we had to the Church." ${ }^{28}$ Finally, the dissenters explained that they were duty-bound to obey God by forming a new church. They asked First Church's "prayers and Blessings" but were done asking for their permission. First Church responded by dubbing the dissenters "scismaticks" and voting once again to deny them communion. ${ }^{29}$ The dissenters left the meetinghouse and soon after sent a letter to five neighboring churches to ask for their help in forming the new congregation. ${ }^{30}$

${ }^{27}$ Result of the second council, in Third Church Narrative, 64-65.

28 "Dissenters letter to the church," 4 May 1669, in Third Church Narrative, 74-75.

${ }^{29}$ Third Church Narrative, 76. In addition to both council results, the dissenters also had the approval of five magistrates-Daniel Gookin, Daniel Dennison, Simon Willard, Richard Russell, and Thomas Danforth-to form a new church in Boston. Messages of support from Simon Broadstreet and John Pinchon were appended. See "Magistrats approbation," 22 April 1669, in Third Church Narrative, 77.

${ }^{30}$ Dissenting brethren to five churches, 8 May 1669, in Third Church Narrative, 78; Hull Diary, 229-230. The new church embraced the Halfway Covenant; one of the founders, Joshua Scottow, had five adult children who joined the new church in halfway status in 1669. His four daughters later joined in full communion. Hamilton Andrews Hill and George Frederick Bigelow, eds., 
Two years and two church councils after the controversy began, the dissenters had given up fighting for their release from the First Church covenant and established, without dismission, their own church—an unusual step justified by the results of both councils recommending that they be dismissed without censure. While Boston's Second Church had been established with First Church's consent in the north end of the peninsula in 1649 to accommodate the town's growing population, this new church had been founded "in a storme." 31 The chaos that had begun in the First Church meetinghouse had become a colony-wide issue and revealed less-than-godly behavior in Boston's godly congregation. New Haven's letter purportedly granting Davenport's dismission was proved to be a forgery committed by the elders of First Church and by Davenport's son, who had shortened the real letter and altered its meaning. When the full letter from New Haven was revealed in June 1669, it "became discourse in the Towne" that the church had been so deceived. Davenport and the elders were forced to defend themselves from an onslaught of rebukes from ministers throughout the colony. $^{32}$

An Historical Catalogue of the Old South Church (Third Church) Boston, 1669-1882 (Boston: David Clapp \& Son, 1883), 220.

${ }^{31}$ Third Church Narrative, 80.

${ }^{32}$ Third Church Narrative, 81 . Letters from the ministers are in Third Church Narrative, 8489. See also Hutchinson, History of the Colony and Province of Massachusetts-Bay, 231-232. The forgery appears to have been perpetrated by Davenport's son with the consent of Allen and Penn on the grounds that the letter's author, Nicholas Street, was not speaking for the New Haven church in denying the dismission, and that the unedited letter had "in it many mistakes, and injurious expressions."

According to Davenport, the "extract" only "left out some superfluities and such things as did not properly belong in it," and it therefore did not constitute a forgery. The controversy within First Church over the letter was brought to an official end when the elders confessed to the congregation, but the tension between First and the other ministers seems to have been left unresolved. The controversy 
This forgery was yet another dramatic turn in a story that revealed how easily tensions in the congregational system could threaten to unravel the New England Way. The Lord's Supper, the Puritans' most important sacrament, had been used as a tool to ensnare and manipulate the dissenters. First Church rejected two council results, and in fact rejected any advisory role for councils at all, threatening the only mechanism through which congregational polity could maintain anything resembling coherence or orthodoxy. Church meetings to discuss the crisis attracted standing-room-only crowds of Bostonians to the First Church meetinghouse, and the strain of attempting to mediate the dispute led (at least indirectly) to the death of Richard Mather, one of the colony's most eminent founding ministers. Davenport did not survive the ordeal either, though his age was as likely a factor as the controversy; he died at the age of 71 , less than a year after Third Church was formally established. ${ }^{33}$

With the forming of the new covenant and church, the first phase of the conflict had ended. A group of male dissenters and the "major part" of the church had battled for dominance in their church - a minority of laymen had labored to have their say against the majority, and a conflict rooted in the Halfway Covenant had come to center around the church's right to refuse the dissenters their requested dismissions. In fighting for their dismissions and the right to form a new congregation, the dissenting brethren had challenged the church elders and minister in public meetings. The dissenters stood up and argued their case before mixed congregations, petitioned further alienated First Church from its neighbors but became less pressing after Davenport's death in March 1669/70.

${ }^{33}$ Third Church Narrative, 44-45, 47-49, 76, 80-83, 165. 
for help from magistrates and neighboring churches, and eventually affixed their names to a new church covenant. When their wives sought to join the new church, however, these options were unavailable to them because they were women.

If the dissenters' wives had been included in the accounting of dissent at the beginning of the crisis, the minority would not have seemed so minor-rather than twenty-eight men, the dissenters actually numbered nearly sixty, which is not such a small minority. The wives had not been included, however, when the dissenters left their covenant with First Church and these women remained members of the old church after the new covenant was signed. After the men emerged from the standoff and formed a new congregation, First Church refused to recognize their church and refused to release the women from their covenant. The wives' efforts to gain release from their covenant obligation so that they could join the new congregation constituted a second phase of the schism. The first phase had been a battle over sacramental practice and church governance and was conducted on the battlefield of public affairs. The men on both sides of the conflict had used every tool at their disposal in service of their cause, and it was through the collective efforts of the dissenting men, church councils, and magistrates' rulings that they were allowed to form the new church. During the second phase, the same tools were employed but with a fundamental difference: The women's activities were adapted to conform with gender role expectations and to their simultaneous statuses as women, wives, and church members. The second phase of the schism shows the ways in which women's loyalty to conflicting covenants and their adherence to social expectations limited their 
ability to shape their own lives as church members, but also shows the ways that Puritan society allowed opportunities for women to act in the service of their own consciences. 


\section{Chapter Three}

\section{"To provide for our own peace and spirituall comfort" The Dissenting Wives of Third Church, Boston}

More than five hundred people had jammed into Boston's First Church meetinghouse on February 12, 1668/69, to witness the elders propound their case against three deacons who stood accused of "high contempt of the holy ordinance of god" for refusing to take the sacrament because they objected to the church's decision to call John Davenport to their pulpit. ${ }^{1}$ Two previous meetings for this purpose had descended into chaos and ended without resolution, and while the three deacons were discharged of their duties on that February day, the bigger questions of the crisis were left unresolved. A rift had been created in the congregation and this led a significant minority of the church to abandon their covenant and form a new congregation.

The fates of the deacons and of all the dissenters had been in the hands of men, as the fates of the two churches and of the dissenters' wives continued to be. The women had been left behind to seek their own dismissions, and their efforts to do so show women confronting an inherent paradox within Puritan society and theology that simultaneously positioned women as subordinates and as equals. Conflicting covenants and contradictory prescriptions for both women and male authorities trapped the women and the churches in a conflict that lasted five years. Throughout this dispute, the wives of Third Church's founders were able to advocate for themselves as believers and church members without violating the bounds of Puritan

${ }^{1}$ Third Church Narrative, in Hamilton Andrews Hill, History of the Old South Church (Third Church) Boston, 1669-1884 (Boston: Houghton, Mifflin and Company, 1890) [hereafter History of the Old South], 47. 
hierarchy and its prescribed behavior for women. During their five-year effort to join the new church, the wives of the Third Church dissenters were not subjected to gendered criticisms. Here, we find seemingly conventional women-not heretics or agitators-exercising spiritual and social agency, asserting their right not only to join their husbands in worship but also to follow their own consciences and doing so in ways that were compliant with the roles prescribed to them within the Puritan system. We also find, however, that the patriarchy was not an illusion. In the end, the women were unable to free themselves without male support; they finally gained admission to the new church through the efforts of Third Church's minister and a church council. The women's efforts to free themselves from their covenant obligation to First Church reveal that the patriarchy in New England was neither impenetrable nor absolute, but the women's reliance on men to advocate for them reveals that the patriarchy was real.

Puritan society was infused with hierarchy and wives were commanded to be subordinate to their husbands in almost every regard; the covenant made between the church and its members, however, was individual, and dismission for the wives was not implied by the husbands' release. The contradiction between women's status as subordinates in their marital relationships and the individual nature of their salvation presented a problem for membership and dismissions.

Congregations had faced this question-whether wives needed individual dismissions after their husbands were dismissed to another congregation-early in 
New England's settlement. Reverend John Fiske recorded a debate over an admission to the Salem church in which a woman had failed to seek a letter of dismission from her previous church; "she thought not herself bound to require their letters" since her husband had already joined the congregation. The pastor posed the question, "how far or whether a wife ought to seek letters of dismission if the man be dismissed," but Fiske did not record the church's answer. ${ }^{2}$ Later, Fiske recorded a debate over the admission of women whose husbands were dismissed from the Salem church to the new church at Wenham. Some argued that the wives were "conceived of to be dismissed with their husbands," but the church voted that the wives still had to give a relation to their new congregation, indicating that their membership was conceived of as simultaneously bound to their husbands' and independent. ${ }^{3}$

Women's status as both individuals and subordinates, and the membership crisis that contradiction caused for the dissenters' wives in First Church, might have been no conflict at all if the wording of the dissenting brethren's requests had been consistent. When the dissenters in First Church finally decided to seek release from their covenants, their initial request for dismission had included their "Deare relations." ${ }^{4}$ When this request was read to the congregation in August 1668, the

2 John Fiske, The Notebook of the Reverend John Fiske, 1644-1675, ed. Robert G. Pope (Salem, MA: Essex Institute, 1974), 244.

${ }^{3}$ Fiske, Notebook, 6 .

${ }^{4}$ Dissenters' request, 10 August 1668, in Third Church Narrative, 28. The men may have been referring to their children who had not yet joined the covenant as adults; Richard Mather noted that members who moved to another church should also obtain dismission for their children. Richard Mather, A Disputation Concerning Church-Members and their Children (London: J. Hayes for Samuel Thomson, 1659), Wing W1271A, p. 14-15. 
church asked the dissenters to leave the meetinghouse so that they could discuss it; after the dissenters withdrew, the church asked their wives to leave as well because the dissenters' request had indicated a desire that their "Relations might be dismist with them." The men's subsequent appeals for dismission, however, were for themselves only and did not explicitly include their wives. The dispute between First Church and the wives spanning the next five years resulted from the contradictions inherent in women's membership and the unresolved question of whether First Church's objection to the new church could or should override the duty of women to follow their husbands. ${ }^{5}$

After the new church had been established, First Church turned its attention to the dissenters' wives, who remained members of the old congregation. At the end of June 1669 , the month following the formal establishment of the new church, First Church held a meeting to assuage members' lingering doubts about Davenport's dismission from New Haven, and the old church "put forth all the sisters, not suffering them to be present, as if their consciences were not to be considered in satisfaction."6 The motives for this action were not recorded, but it is likely that the women were sent away for the same reason they had been before: As wives of the dissenting brethren, they were participants in the controversy. First Church also may have thought the wives would act as spies for the dissenters.

${ }^{5}$ Third Church Narrative, 29. Hill posited that the men wished to shield their wives from "the brunt of the conflict"; "they thought, no doubt, that their church once fully organized, and the ordinances of the gospel established among them, no prolonged opposition would be made to the members of their families in following them." See Hill, History of the Old South, 176.

${ }^{6}$ Third Church Narrative, 83. 
In the coming months and years, with the dissenting men now out of reach, the focus of the disagreement shifted within the church to the wives of the dissenters. The contradictions in women's covenants allowed First Church to prolong the crisis; the women's status_-and therefore the new church's status-remained unresolved so long as the women were not released from their covenant with the old church. If First Church had allowed the wives to leave, the inter-church crisis would have been de facto resolved in the new church's favor.

\section{"one to another all of them are Sisters" Communion of Churches}

In February 1669/70, less than two weeks after Third Church had ordained Thomas Thatcher as their minister, the elders of First Church "warned" the women to attend a church meeting. In that meeting, the assembled congregants of First Church were told that unless they were traveling or their church had no officers to administer the sacrament, it was a "breach of covenant" to hear a sermon or partake of the Lord's Supper at a church other than the one of which they were members. It was an ironic command, given the Puritans' practice of "gadding to sermons" in old England, and also imposed unprecedented restrictions on accepted principles about the relationship among godly churches. This was clearly directed at the wives of the dissenters, forbidding them to take the sacrament with their husbands at the new church now that Third Church had both a meetinghouse and a pastor to administer the Supper. No stretch of the imagination could have used "travel" as a justification for attendance at 
the newly built Third Church meetinghouse, since it was located just two hundred yards from First Church in the center of Boston. ${ }^{7}$

Puritans had been punished in England for going to parishes or preaching places other than their own churches to hear sermons and sometimes to take the sacrament, a practice known as gadding. They did this not only in cases where their own parish had no preaching ministry, but also to hear renowned preachers or to hear sermons that aligned more closely with their religious views. They were punished for this practice because it undermined the authority of the Church of England and called into question the efficacy of the official homilies. ${ }^{8}$ Because there was no parish system in New England, it is possible that the practice of gadding was rendered irrelevant by the voluntary nature of settlement and church membership, by the requirement of a preaching ministry, and by the congregational tenet of the "communion of churches." Church members still seem to have occasionally sought

${ }^{7}$ Third Church Narrative, 153, 163-164. Like every other part of Third Church's founding story, the establishment and construction of their first meetinghouse is at turns intricate, surprising, and humorous. Good summaries can be found in Mark A. Peterson, The Price of Redemption: The Spiritual Economy of Puritan New England (Stanford, CA: Stanford University Press, 1997), 42-45; and in Robert G. Pope, The Half-Way Covenant: Church Membership in Puritan New England (1969; Eugene, OR: Wipf and Stock, 2002), 163-165. Documents pertaining to the dispute over the meetinghouse's location, along with editorial commentary, can be found in Hill, History of the Old South, 128-153.

${ }^{8}$ On the practice of gadding to sermons in England, see Kenneth Charlton, Women, Religion and Education in Early Modern England (London: Routledge, 1999), 154-155; and Martin Ingram, "Puritans and the Church Courts, 1560-1640," in The Culture of English Puritanism, 1560-1700, ed. Christopher Durston and Jacqueline Eales (New York: St. Martin's, 1996), 87. Settlers in Massachusetts were clearly familiar with both the term and its meaning; John Winthrop paradoxically used it as an insult against Anne Hutchinson during her trial. See Jane Kamensky, Governing the Tongue: The Politics of Speech in Early New England (New York: Oxford University Press, 1997), $231 \mathrm{n} 48$ and $233 \mathrm{n} 62$.

${ }^{9}$ For the departure from the parish system, see Anne S. Brown and David D. Hall, "Family Strategies and Religious Practice: Baptism and the Lord's Supper in Early New England," in Lived 
worship at churches other than their own, however, whether out of convenience or due to other factors.

New England's first-generation ministers asserted that the communion of churches was an important part of the emerging New England Way. John Cotton described this idea as an extension of the communion of saints, which was the founding principle of any congregational church. While each church was independent, the churches of New England were related to each other and bound together in "Brotherly equalitie, or co-ordination."10 Membership in one church did not convey membership in all, but visitors could be admitted to the Lord's Supper if they were members in good standing of another church in good order. Visitors were accepted at the Lord's Table not simply as individual believers, but also as covenanted members of a congregation. The Supper was a seal not only of the saint's covenant with Christ

Religion in America: Toward a History of Practice, ed. David D. Hall (Princeton, NJ: Princeton University Press, 1997), 44; and Robert M. Kingdon, "Protestant Parishes in the Old World and the New: The Cases of Geneva and Boston," Church History 48 (1979): 290-304. On settlement patterns, see Virginia DeJohn Anderson, New England's Generation: The Great Migration and the Formation of Society and Culture in the Seventeenth Century (Cambridge, UK: Cambridge University Press, 1991), chapter 3. For voluntary nature of church membership, see Brown and Hall, "Family Strategies," 44. On the Puritan ideal of a preaching ministry, see Patrick Collinson, The Elizabethan Puritan Movement (Oxford: Clarendon Press, 1967), 41-42. On the preaching ministry in New England, see David D. Hall, The Faithful Shepherd: A History of the New England Ministry in the Seventeenth Century (Cambridge, MA: Harvard University Press, 2006), 5; Edmund S. Morgan, Visible Saints: The History of a Puritan Idea (Ithaca, NY: Cornell University Press, 1963), 6-9, 123; Francis J. Bremer, The Puritan Experiment: New England Society from Bradford to Edwards (Hanover, NH: University Press of New England, 1995), 25-28; and Foster, The Long Argument, 21-23.

${ }^{10}$ John Cotton, The Way of the Churches of Christ in New-England (London: Matthew Simmons, 1645), Wing (2 $2^{\text {nd }}$ ed.) C6471, p. 102-103. 
and with their own church, then, but also a seal of the churches' communion with each other. $^{11}$

In defending New England's stance toward members of the Church of England, Richard Mather had made it quite plain that admitting a member of another church to communion was recognition that the church in which they were covenanted was a "true Church." He explained that sharing the Supper was "not only an Act of Communion with the persons themselves, but also with the Congregation of which they are."12 John Davenport had explicitly endorsed this policy in 1639, stating clearly that "members of other Churches well known and approved, by virtue of communion of Churches, do mutually, and without exceptions communicate each of them at others Churches." 13 Of course, these assertions were written largely, it would seem, to placate New England's opponents in old England during the first years of settlement, justifying their peculiar practices as non-separatist—a task which was perhaps less critical now that the colony and its religious practices were established and, in the aftermath of the English Civil Wars, New England's ministers showed

${ }^{11}$ Letters of recommendation were required if a member was going to leave their congregation for any length of time to "reside and continue in another Towne," but there is no indication that a formal recommendation was required to receive communion at another church on an occasional basis. See Cotton, Way of the Churches, 103. Janice Knight has argued that the communion of churches "was not determined by geographic proximity" and was expanded by some clergy in New England, including Cotton and Davenport, to include a concern for the "church international." Knight, Orthodoxies in Massachusetts: Rereading American Puritanism (Cambridge, MA: Harvard University Press, 1994), 154-155, 160-162.

${ }^{12}$ Richard Mather, Church-Government and Church-Covenant Discussed (London: R. O. and G. D. for Benjamin Allen, 1643), Wing ( $2^{\text {nd }}$ ed.) M1270, p. 29.

${ }^{13}$ John Davenport, An Answer of the Elders of the Severall Churches in New-England unto Nine Positions (London: T. P. and M. S. for Benjamin Allen, 1643), Wing ( $2^{\text {nd }}$ ed.) M1270, p. 78. 
increasing hostility to the establishment they had once committed to reforming. ${ }^{14}$

There seems not to have been any change to the general understanding, however, that members of New England's covenanted churches could be offered (and by implication could receive) the Supper at a church other than that with which they were covenanted. It was likely also incumbent upon members to communicate only in congregations in good order, though it was not specifically commanded.

The New England Way, then, allowed covenanted church members to visit other churches for both sermons and the Supper. The rule governing this act was usually discussed in the context of travel rather than specifically to hear a different preacher; John Cotton's explanation assumed that the visitor was "occasioned to rest with [them] on the Lords day, when the Supper cometh to be administred." Other reasons would have been largely irrelevant in Cotton's Boston (and in most other Massachusetts Bay towns), which had only one church. ${ }^{15}$ By the time of Davenport's instruction, however, a second church had been established in the north part of Boston

${ }^{14}$ Foster, The Long Argument, 195-196; Holifield, Covenant Sealed, 161-163. On nonseparating congregationalism, see Perry Miller, Orthodoxy in Massachusetts 1630-1650 (1933; Gloucester, MA: Harvard University Press, 1965), chapter 4.

${ }^{15}$ Cotton, Way of the Churches, 103. John Cotton had in fact envisioned a society wherein each town had only one church, but the early settlers likely did not foresee the population growth and geographic reach that Boston soon had. Communities in the area surrounding Boston quickly established their own congregations. A separate church was established at Charlestown in 1632 because members had difficulty traveling to the relocated congregation in Boston, and a church was established in the new town of Braintree (Mount Wollaston) for the same reason in 1636-1639. There was no other church in Boston proper, however, until Second Church was established in 1650. See Darrett B. Rutman, Winthrop's Boston: A Portrait of a Puritan Town, 1630-1649 (Chapel Hill: University of North Carolina Press, 1965), 60, 95, 260, 280-283. The two existing meetinghouses were evidently no longer large enough to accommodate Boston's growing population, and this was the reason given for the town's approval of a third church in Boston. A Report of the Record Commissioners of the City of Boston, containing the Boston Records from 1660 to 1701, Seventh Report of the Record Commissioners (Boston: Rockwell and Churchill, 1881), 49. 
for some twenty years, and some members of First Church were in the habit of attending Second Church and taking the Supper there. ${ }^{16}$

Davenport's instruction would have ended the practice of attending neighboring churches, making travel the only allowable reason for First Church members to communicate at another church. His rigid definition placed tighter bounds on the communion of churches and aligned with the churches' responsibility to protect their members from separating on spurious or heretical grounds. It also aligned with Davenport's rigid views on the independence of congregations that led him to reject synods and councils as legitimate tools in governing the New England Way. As a first-generation minister and long-time defender of congregationalism, he was prone to drawing rigid lines regarding church practices. ${ }^{17}$

The record does not reveal with any certainty how many members of First Church endorsed Davenport's restriction on the communion of churches, saying that it was approved by silence rather than by a vote. The dissenting wives, fearful of offending First Church and coming under a censure that would prevent them from seeking membership in another church, did not attend when the sacrament was offered at Third Church two days later. That Davenport's unusual directive, a break with New England tradition and Puritan tenets, was intended for them only-and that the new

${ }^{16}$ Third Church Narrative, 164. Davenport's directive does not seem to have been intended to keep First Church members from hearing pro-Halfway Covenant opinions at Second Church, since Increase Mather did not change his stance on the practice until at least 1671. See Robert Middlekauff, The Mathers: Three Generations of Puritan Intellectuals (Berkeley: University of California Press, 1999), 122, 386n24.

${ }^{17}$ Cotton, Way of the Churches, 105; Knight, Orthodoxies, 184-188. 
church had the support of other congregations - was confirmed when "sundry Brethren and sisters of other Churches did partake [at Third Church] by vertu of Communion of Churches."18 This shows not only that other churches recognized Third Church as a church in good order, but also that Davenport's restriction on communicating outside of one's covenanted congregation was not accepted practice in other churches. ${ }^{19}$

The dissenters' wives and the two churches were now trapped in a web of conflicting prescriptions. If First Church were to grant dismission to the wives to seek membership in Third Church, they would be tacitly acknowledging that the new church was an orderly and godly congregation. For Third Church to admit the wives to membership without dismissions from their previous congregation would have violated church order. Despite the unusual circumstances of their founding, Third Church adhered to the New England Way and could not jeopardize their standing as a church in good order by admitting the wives without dismissions. Third Church also hoped to establish regular relations with First Church and could not give the old church any more ammunition to question the new church's validity. The wives could

${ }^{18}$ Third Church Narrative, 164. Joseph B. Felt commented on the "rare occurance" of this declaration. See Felt, The Ecclesiastical History of New England; Comprising Not Only Religious, But Also Moral, and Other Relations, (Boston: Congregational Library Association, 1862), 2:442.

${ }^{19}$ Other churches recognized Third Church by dismissing their members there. Of these, Dorchester was the first. Records of the First Church at Dorchester in New England 1636-1734 (Boston: George H. Ellis, 1891) [hereafter Dorchester Church Records], 61-62; Hill, History of the Old South, 165-166n3. The vote in Dorchester on Sister Blake's dismission to Third Church was a closely divided one, but they released many other members to the new church in subsequent years. Under Richard Mather, Dorchester had cautiously adopted Halfway principles in 1655, but opposition from the congregation kept them from fully implementing Halfway membership until 1677. See Pope, Half-Way Covenant, 134-135, 188, 226-231; Felt, Ecclesiastical History, 2:134. 
not preserve family order by worshipping with their husbands without violating their own church covenants, and First Church refused to release them from their covenant obligations; they could not obey one rule without violating the other. The women and the two churches were now engaged in a struggle that revealed contradictions regarding women's membership that were embedded in the tenets of their faith, a conflict which took five years to reach a conclusion and even then was not fully resolved.

\section{"the duty which lyeth upon us" Deference and Defiance}

On February 28, 1669/70, three days after his directive was issued, two of the women met with Davenport and sought a compromise, offering that they would not seek dismission from First Church at this time if he would allow them to attend church with their husbands. ${ }^{20}$ Importantly, they explained that they requested this concession only because they were "satisfied in the orderly constitution of that Church whereof their husbands were members." ${ }^{21}$ The women sought to worship with their husbands as their marriage covenant required, but they were also engaged with ideas of church polity in a way that allowed them to make a judgment about the new church's validity. As visible saints, they would have been expected to show proof of knowledge as well as grace before their admission to membership, so it should not be surprising that they

${ }^{20}$ Unfortunately, the record does not indicate which of the sisters visited Davenport to offer this deal. Third Church Narrative, 164.

${ }^{21}$ Dissenting wives to First Church, 5 March 1669/70, in Third Church Narrative, 164. 
were able to make this assertion; it is noteworthy, though, that they would disagree directly with their minister about the validity of a church. ${ }^{22}$

Davenport evidently refused their compromise, because the same wives soon met with his colleague, James Allen, and Elder James Penn to formally request dismission for themselves and the other wives. It is likely that the women received men's help in drafting their request, but it is not necessarily the case that the women were not active in formulating their argument. ${ }^{23}$ The women not only presented written requests but also met with Davenport, Allen, and the elders to argue their case, and there is no indication male advocates attended these meetings with them. It is likely, therefore, that the women were actively arguing on their own behalf in these meetings. Women were admonished to be silent in the churches, but this did not preclude an ability to advocate for their own spiritual condition in private conference, even when it meant actively disagreeing with their male superiors. ${ }^{24}$

${ }^{22}$ On knowledge as a requirement for admission, see Morgan, Visible Saints, 88; and Darrett B. Rutman, American Puritanism: Faith and Practice (Philadelphia: J. B. Lippincott, 1970), 111. On the intellectual lives of women in seventeenth-century New England, see Dana Rose Comi, "'In the Shade of Solitude': The Mind of New England Women, 1630-1805" (PhD diss., Brandeis University, 2003), chapter 1. Comi noted that "Puritanism was not a passive religion intellectually" (36). On public versus private speech, see Kamensky, Governing the Tongue, chapter 3.

${ }^{23}$ Third Church Narrative, 164. Hill's examination of one letter submitted to First Church by the wives determined that the handwriting was that of John Hull and eight of the women's "signatures" were also in his hand. Hill, History of the Old South, 202n1. Porterfield argued that, while only about one-third of New England's women could both read and write, wives of wealthy merchants (like many of Third Church's founders) would have been more likely to have the skill. Amanda Porterfield, Female Piety in Puritan New England: The Emergence of Religious Humanism (New York: Oxford University Press, 1992), 169n2. While Hull may have acted as an amanuensis for the women, it is my contention that the effort to free them from First Church was a collaborative one.

${ }^{24}$ For more about private conferences, see Charles E. Hambrick-Stowe, The Practice of Piety: Puritan Devotional Disciplines in Seventeenth-Century New England (Chapel Hill: University of North Carolina Press, 1982), 152-155. Hambrick-Stowe's discussion of private conferences implied that they 
In the written request signed by twenty women and submitted March 5, 1669/70, the sisters offered two arguments for their dismission. ${ }^{25}$ Their first and primary argument aligned with the Fifth Commandment and with the patriarchal structure which followed from it. Wives were commanded by scripture and by the church to rely upon their husbands for spiritual guidance, and families were meant to worship together; they knew that "confusion, disorder, and disturbance... will unavoidably follow, when husbands goe to one place and wives to another to worship." While the wives first noted their duty to obey and follow their husbands, they also cited their "owne affections and desires earnestly pressing" them to join Third Church. It was not simply wifely duty, but duty to God and to their own souls that led them to seek dismission. Like their husbands' initial request for dismission, this brief request did not mention any of the specific theological differences that led the men to separate from their covenant. ${ }^{26}$

were meant for ministers to provide guidance to parishioners, but this incident indicates that they could also be hostile or confrontational. On women's private speech, see Kamensky, Governing the Tongue, chapter 3; Laurel Thatcher Ulrich, "John Winthrop's City of Women," Massachusetts Historical Review 3 (2001): 23.

${ }^{25}$ Several wives of the dissenting brethren, along with many other women, were admitted to Third Church prior to the resolution of the controversy, indicating that they were either members of churches other than First Church or were not members of any church before they joined Third Church. The names of the signatories to the women's petitions fluctuated slightly over the course of the crisis, and two of the women whose names appear on this letter, Hulldah Davis and Elizabeth Usher, died before the wives were admitted to Third Church. For biographical sketches of the founders, see Hill, History of the Old South, 113-123. Biographical sketches of the members who joined between 1669 and 1674 (including expanded versions of those in History of the Old South) can also be found in Hamilton Andrews Hill and George Frederick Bigelow, eds., An Historical Catalogue of the Old South Church (Third Church) Boston, 1669-1882 (Boston: David Clapp \& Son, 1883), 215-256. The names signed to each of the women's petitions can be found in the Third Church Narrative, 164, 168, and 202. A chronological list of Third Church members for the first five years can be found in Hill and Bigelow, eds., Historical Catalogue, 5-10. See also Appendix B. 
The sisters delivered this letter to Elder Penn and asked that he convey it to the members of First Church. After three days, Penn opined that the wives' letter was "too long a business" (though it was much shorter than their husbands' original request) and refused to read the petition to the church as it had been submitted. ${ }^{27} \mathrm{He}$ suggested that the sisters should shorten their request to "two or three lines" requesting dismission to "a church in order" rather than specifically asking for release to Third Church, and that each sister should submit her own request rather than requesting dismission in a group petition. Penn's instructions indicate that there were two problems with the wives' request: Approving it would have required First Church to recognize the dissenters' church as legitimate because it specifically asked for dismission to the new church; and it was submitted collectively by the wives. Collective petitions were never questioned when the men submitted multiple requests and petitions in the names of all the dissenting brethren, so this indicates that women's

${ }^{26}$ Dissenting wives to First Church, 5 March 1669/70, in Third Church Narrative, 164. Porterfield argued that it was "unprecedented" for women to petition the church in this way and that it showed "considerable political self-consciousness." Their petition does not seem particularly unprecedented, given that women habitually requested dismissions when moving from one church to another. Their collective action does not seem to have been exceptional either; Mary Beth Norton recounted a case of women submitting petitions to the General Court on behalf of an imprisoned midwife. I am not convinced that the women's actions within the church can necessarily be construed as political action, since the political upheaval surrounding Third Church's founding seems parallel to their actions rather than intertwined. Porterfield, Female Piety, 122. See also Mary Beth Norton, Founding Mothers and Fathers: Gendered Power and the Forming of American Society (New York: Vintage, 1996), 205-206.

${ }^{27}$ For the wives' petition and response see Third Church Narrative, 164-165. For the dissenting men's original request, see Third Church Narrative, 27-28. In Hill's published versions, the wives' request runs sixteen printed lines, while the husbands' is twenty-eight lines. 
collective action was less acceptable and perhaps more threatening to the male authorities. $^{28}$

After being assured that Penn was not attempting to ensnare them, the sisters each submitted individual requests, but not exactly as Penn had requested: Twenty identical petitions were submitted, each replicating the original request "only alltering the term we to me." Davenport's death a few days later did not diminish the old church's hostility toward the new church, and when the sisters' requests were read to the church members two weeks later they were rejected by a vote "after much agitation." 29 A member of First Church argued in the meeting that they should give the petitions further attention; he suggested that if the sisters could not be dismissed to Third Church then perhaps they could be given an "indefinite dismission." This would have allowed them to join any church in order but would have allowed First Church to avoid explicitly recognizing Third Church as a legitimate body. An indefinite dismission would not necessarily have been an unusual step; many letters of dismission released the member to the church where they intended to covenant or to "any other Church in gospel order," and this seems to have been Penn's intention in his earlier instructions to the wives about revising their letter. ${ }^{30}$

${ }^{28}$ It is interesting that while First Church seems to have been particularly troubled by the women's collective action, the Third Church Narrative rarely identifies the actions of individual women in the dispute and instead usually refers to them collectively as "the wives" or "the sisters." For the names of the women who signed the petitions, see Appendix B.

${ }^{29}$ Third Church Narrative, 165-167. 68.

${ }^{30}$ See, for example, the 1672 letter of dismission for Anne Latimor in First Church Records, 
James Allen, now serving alone in the pulpit at First Church, refused to act on the member's suggestion and argued that "If the sisters had any such motion to make, they might express it themselves." The member may have been baiting Allen, but at the very least the women were prepared for his objection, because one of the sisters produced a letter making just such a request and handed it up to the elders. The entire text of the request was as follows:

We having presented our humble request for a dismission as we beleive according to rule, upon reasons renderd in that request, to that Church whereof our husbands are and perceiving that it is not acceptable to you doe humbly request that you would grant unto us an indefinite dismission, and soe liberty to joine unto any Church in order. ${ }^{31}$

The women's defiance in these proceedings, while brazen, stayed within the bounds of proper behavior since they seem to have remained silent when handing up their requests; the prohibition against women's speech in the meetinghouse did not extend to expressing themselves silently in writing. Written communication was easier to ignore, however, and the elder stuffed the request in his pocket without reading it and without relating it to the congregation. ${ }^{32}$

An indefinite dismission appears to have been one of the few options for facesaving compromise for First Church, and the reason for the elders' refusal is unclear. In all probability, they feared any dismission could be seen as an implicit acceptance of Third Church's existence. It is also possible, though unlikely, that they still hoped the dissenting men would yet be rebuked and return to First Church. The elders of

${ }^{31}$ Dissenting wives to First Church, 25 March 1669, in Third Church Narrative, 167.

${ }^{32}$ Third Church Narrative, 167. On written versus spoken communication, see Kamensky, Governing the Tongue, 85-86, 92-93. 
First Church, with the apparent assent of most of the members, fought to hold the dissenters' wives in their covenant agreement for a combination of religious and personal reasons. First Church was holding fast to the admonition that a church should not dismiss members who sought release from their covenant for what they saw as inappropriate reasons, even though their most eminent former minister, John Cotton, had specifically cited disagreement over a minister as a case in which a church was "bound to yield unto [a member's] equall and just desire" for dismission. ${ }^{33}$ First Church did not recognize Third Church as a legitimate congregation and therefore thought they had a responsibility to members under their "watch and care" to protect them from error. First Church's perceived responsibilities to their members and the covenant, their determination to follow through on the efforts of their recently deceased minister, and their personal animosity toward the new church grown out of the now years-old conflict were likely all factors in the church's refusal to release the wives. $^{34}$

${ }^{33}$ John Cotton, Certain Queries Tending to Accommodation and Communion (London: M. S. for John Allen, 1654), Wing C6416, p. 19. See also Richard Mather, A Platform of Church Discipline (Cambridge, MA: S. G., 1649), Wing P2396, p. 19; Cotton, Way of the Churches, 105. First Church ignored the corollary explanation offered both in the Platform and by Cotton that a member should not be held who manifestly refused to stay. Cotton said that if "they shall see the bent of his spirit unremovably set upon removal" then a church should not continue to hold the person in covenant. They should not, Cotton explained, be "willing to make the Church of God a prison to any man." Punishment for this violation, Cotton said, would usually come in a "bitter curse" from God, and those who had departed in such a manner would likely seek to rejoin their original congregation in time. The Platform said that if "the person not to be perswaded, it seemeth best to leave the matter unto God, \& not forcibly to detayn him." First Church seemed instead to be adhering to the assertion in the result of the Synod of 1637 (addressing the Antinomian crisis), which said that "as the admission of a member was by the consent of the whole, so likewise must his dismission be." John Winthrop, "A Short Story of the Rise, reign, and ruine of the Antinomians, Familists, \& Libertines," in Hall, ed., Antinomian Controversy, 242.

${ }^{34}$ Peterson, Price of Redemption, 46. 
When the Lord's Supper was celebrated at both churches three days later, on March 27, 1670, some of the dissenters' wives (and at least one other female member of First Church whose husband was not a Third Church member) attended the new church rather than the old. None of the dissenting sisters attended the sacrament at First Church the following week, both "for peace sake" and because they had been assured they would not be censured for absenting themselves. ${ }^{35}$ Soon after, however, the sisters gave up any pretense of being conciliatory or submissive after their efforts to follow the advice of both Elder Penn and John Oxenbridge, who had been called to fill the vacant pulpit in First Church, left them still bound to the old church.

Mary Savage, Judith Hull, and Susanna Dawes were invited to a meeting with Oxenbridge, Allen, Penn, and "some other Brethren of the old church" on April 25, 1670 , to defend the wives' participation in the Supper at the new church the day before. The women explained that on April 18 Elder Penn had recommended in separate meetings with both Dawes and Hull that the sisters all communicate with their husbands at Third Church as a way of getting the church to address their petition. They initially resisted, fearing that Penn was trying to use the sacrament to ensnare them as had been attempted with their husbands, but the elder insisted that he would "stand betwixt them and trouble" because he "knew no sin in their partaking with their

${ }^{35}$ Third Church Narrative, 167-168. On censure and excommunication, see Mather, Platform of Church Discipline, 43-49; Cotton, Way of the Churches, 89-102; and David C. Brown, "The Keys of the Kingdom: Excommunication in Colonial Massachusetts," New England Quarterly 67 (1994): 531566. 
husbands. ${ }^{36}$ On April 21, three days after their meeting with Penn, Oxenbridge had met with Mrs. Hull and Goody Dawes and recommended the same course. ${ }^{37}$

When he was initially being courted to the pulpit at First Church, Oxenbridge had indicated to both the wives and to First Church a desire that the issue with the wives, whom he termed "half-members," be resolved before his ordination; he evidently did not insist on it, however, and he was ordained on May $4 .^{38}$ Oxenbridge seems likely to have been disposed to resolve the controversy in favor of the wives' dismission. It is interesting that First Church would have called him to the pulpit in the middle of the crisis, since he had been present at the founding of the new church and had in fact preached a sermon at the founding in which he "praysed God that though the day began in a storme yet that it ended in a Calme, and praid that this infant Church might live to condemne their condemners." Perhaps he hoped that First Church's eagerness to ordain a new minister would override their animosity toward the new church and they would grant the dismissions if he indicated his assent.

${ }^{36}$ Third Church Narrative, 168-169.

${ }^{37}$ Porterfield notes that these were "two of the most prominent dissenting women." The records give only a few clues about the details of the wives' organization, but their status and their conferences with both Davenport and the elders indicate that Dawes and Hull may have acted in some kind of leadership capacity in the women's actions. For details about Hull and Dawes, see Porterfield, Female Piety, 122-124.

${ }^{38}$ First Church Records and Third Church Narrative both mention that the call was issued to Oxenbridge on April 10, but they do not note the day of ordination. Histories of First Church often record April 10 as Oxenbridge's day of ordination, but it would have been highly irregular for the church to have ordained him on the day of his call, particularly because representatives from both the civil government and neighboring churches would have been required to be present. The First Church at Dorchester received an invitation to send messengers for the ordination; the invitation was received on April 24 and the ordination was to be held on May 4. The month-long gap between call and ordination was a likely interval, and I believe that the ordination happened in May rather than in April. See Third Church Narrative, 169; First Church Records, 65; Dorchester Church Records, 62. 
Despite his support for the new church, however, by 1671 he was a staunch opponent of the Halfway Covenant. ${ }^{39}$ His request that the "church take some care with their [the wives'] remove before his day of ordination" had given Third Church and the wives some hope that the issue could be resolved and the women could obtain their dismissions. His addition to the ministry at the old church did not, however, diminish the old church's animosity toward the new.

Oxenbridge had advised that the women might risk censure "for the not giving constant attendance upon the Ministrie of the word every Lords day" if they absented themselves from church altogether and that First Church might be more inclined to address their case if they were to all take the sacrament together at Third Church. The wives suggested that they would be willing to ask for dismission again before communicating with their husbands or to wait "half a yeare" if there was hope for a formal and orderly dismission from First Church, but Oxenbridge insisted that the situation had reached a point of "now or never." He told them that they were unlikely to get their dismissions from First Church by passively waiting, whether they delayed

${ }^{39}$ Third Church Narrative, 80, 169; Foster, The Long Argument, 201, 203; Pope, Half-Way Covenant, 176-177. Pope found that the impetus toward innovation came primarily from the ministers, so Oxenbridge may have been one of few available ministers opposed to the Halfway Covenant. This does not explain, however, why he would have previously expressed his support for the new church in its founding. He seems to have arrived in New England from the West Indies in 1669, so perhaps he was cautiously positioning himself in local conflicts when the new church was founded. I have not been able to locate him in a pulpit prior to his call at First Church, so it is unclear why he would have been in attendance at the church's founding. See Pope, Half-Way Covenant, 262-272; George E. Ellis, History of the First Church in Boston, 1630-1880 (Boston: Hall and Whiting, 1881), 129; William Emerson, An Historical Sketch of the First Church in Boston, From Its Formation to the Present Period (Boston: Munroe \& Francis, 1812), 126. Oxenbridge's daughter, Theodora, later married Peter Thatcher, son of Third Church's first minister. See Hill and Bigelow, eds., Historical Catalogue, 241242; Ellis, History of First Church, 129. 
another week or six months, and he encouraged them to take the sacrament with their husbands and then immediately present another request for dismission.

The wives heeded the advice of both Penn and Oxenbridge and took the Supper at the new church on April 24, $1670 .{ }^{40}$ Following the service, the sisters delivered another request for dismission to the elders of First Church. In this request, there was no mention of their obligation to worship with their husbands; they sought release from their "Covenant engagement" in order "to provide for our own peace and spirituall comfort as may, in our own consciences be most suitable to our duety for our ædification in the Lord." ${ }^{41}$ Were the patriarchal system of New England as absolute as has been assumed, and if family had overtaken the church as the most important institution in New England society, arguments based on the marriage covenant or on support of the Halfway Covenant out of concern for the spiritual welfare of their children and grandchildren would seem to be the most useful justifications for requesting dismission. The wives did not mention the innovation or their husbands in this request but instead argued that their own consciences demanded that they find communion with the new church.

The sisters had followed the advice of an elder and the incoming minister, but they did not get the outcome that had been predicted-they had, in fact, been

${ }^{40}$ Third Church records hint at a show of solidarity among the women of First Church, dissenters and not, noting that "many sisters of the old Church: both widows and others did partake with them." Third Church Narrative, 168.

${ }^{41}$ Third Church Narrative, 168. 
ensnared. ${ }^{42}$ They did explain that they sought this dismission after "having had communion with our respective husbands," but the letter did not specifically request a dismission to the new church; still, First Church once again rejected the compromise of an indefinite dismission. On April 28, 1670, the old church responded to their action by passing a vote against the sisters forbidding them to participate in the Lord's Supper at First Church because they had taken communion with their husbands:

[T] hey have had communion with those with whom we have declared we cannot hold communions till they remove offences given us... We do declare, therefore we cannot have communion with such of ours at the Lord's table who have and do communicate with them, until they give us satisfaction, they having broken that rule: I Cor: $10: 32 .^{43}$

First Church did not, however, formally place the wives under censure and did not dismiss them. Though the old church had attempted to "ensnare" the dissenting brethren with the Lord's Supper, the men had never been formally denied communion. The women were now in the unusual position of being members of a church in which they were forbidden the sacrament, and instead could only communicate at the church of which they were not members; they were left without "complete or regular standing

${ }^{42}$ Third Church records indicate that there was some disagreement between Elder James Penn and Anthony Stoddard when Penn's advice to the women was revealed, suggesting that Penn had been in favor of dismissing the wives and was stopped by Stoddard and others: "at this meeting Mr. Stoddard retorted upon Elder Penn that he had never ruled him in the Church nor ever should"; Penn replied that Stoddard "spake very true and that had bin the cause of the trouble which had befallen the church." Penn could not have been blaming Stoddard for the call to Davenport, because Penn seems to have been instrumental in luring Davenport away from New Haven. See Third Church Narrative, 169; and Porterfield, Female Piety, 121. Stoddard seems to have been stoic in his opposition, but there is also some indication that he later married one of the dissenting wives, Mary Savage, after the death of her husband Thomas. See Hill and Bigelow, eds., Historical Catalogue, 249.

43 "Give none offence, neither to the Jewes, nor to the Grecians, nor to the Church of God" (Geneva 1599). Third Church Narrative, 170. 
either in the old church or the new," and this status continued for the next four years. ${ }^{44}$ First Church took this remarkable step without calling the sisters before the church, which was the usual course for disciplinary action. ${ }^{45}$

The women did not advocate on their own behalf again until August 1674, four years later; all petitions to First Church for the wives' dismission during the intervening years were penned and signed by the men of Third Church. Patriarchal restrictions on women's behavior in New England were real, and the women had simply run out of options for obtaining their release through the means that were available to them. They had been effectively, though not technically, excommunicated from the old church and had effective, but not actual, membership in the new church. That the men had not been speaking for these women from the beginning, and that the wives were not included in the husbands' new covenant, shows that the patriarchy did not completely deny women agency, but the women's need for male advocacy shows that there were limits to their autonomy.

\footnotetext{
${ }^{44}$ Third Church Narrative, 177.
}

${ }^{45}$ Third Church Narrative, 170. The line between denial of communion and formal censure was a thin one, but one that First Church evidently did not cross. David D. Hall noted that denial of communion was sometimes imposed "on grounds of pending discipline," but First Church does not seem to have ever pursued formal disciplinary proceedings against the women. Hall, Worlds of Wonder, Days of Judgment: Popular Religious Belief in Early New England (Cambridge, MA: Harvard University Press, 1989), 160. 


\section{"grant your loving dismission unto them" \\ Male Advocacy}

Three months after the women were denied communion at First Church, the minister of Third Church, Thomas Thatcher, sent a letter to First Church advocating for the dismission of the wives, and he sent another letter asking for the same four months after that. The first letter called on First Church to dismiss the wives and to forgive past conflicts. ${ }^{46}$ The second letter, sent in December 1670, reasserted Third Church's standing as a church in good order and renewed the new church's call for a "favorable and loving dismission" for those who desired it. The old church refused both overtures. First Church's reply to the second letter declared that the old church did not want to hear any more of "this matter" until Third Church was willing to admit their errors, to see their "deviation from these rules and acknowledge and repaire them" (at which point First Church would be happy to welcome them back into the fold). ${ }^{47}$

In May 1671, two weeks before a General Court election that saw First Church's political fortunes reversed, the old church did take up the case of Sarah Pemberton. ${ }^{48}$ Her husband was a founding member of Third Church and she had been

\footnotetext{
${ }^{46}$ Thomas Thatcher, "Essay for Accommodation," in Hill, History of the Old South, 174.

${ }^{47}$ First Church elders to Third Church, 16 January 1670, in Third Church Narrative, 180.

${ }^{48}$ On the election of 1671, see Perry Miller, The New England Mind: From Colony to Province (1953; Boston: Beacon Press, 1961), 108-109; E. Brooks Holifield, "On Toleration in Massachusetts," Church History 38 (1969): 188-200; Simmons, "Founding of the Third Church," 248-250. If the election was indeed a referendum on the new church and on the Halfway Covenant, this calls into question the assertion that the laity generally opposed ministers' attempts to implement the innovation. Pope made a convincing case for lay opposition; see Pope, Half-Way Covenant, 133, 214-238. Hall noted that the laity favored the innovation but does not explain how he came to this conclusion; he may
} 
taking communion with him there. In response to a question about her case raised by a First Church elder, the church declared that "we look on ourselves as disingaged of any Covenant duty to her and that shee ceaseth to stand in memberly relation to us." ${ }^{, 49}$ It is unclear why First Church addressed Pemberton's case but refused to settle the cases of the other wives. We know little about either Sarah or her husband, except that he was a brewer and a freeman, and that their son became a minister of Third Church in $1700 .^{50}$ There is no indication that her husband's status led the church to address her case, since there were many more prominent men in the new church than he. Since Pemberton was the only woman dealt with individually, and since her husband could not advocate for her now that he was joined to Third Church, it is possible that she made some agitation on her own behalf to obtain a dismission separately from the other wives. While it is also possible that the church was willing to entertain her request because she submitted it individually, their failure to grant her either a particular or indefinite dismission shows that the women's collective action was not the First Church's only objection to the dissenting wives' efforts. Their declaration that Pemberton was no longer in covenant with them fell short of being a formal dismission, and she did not join Third Church until she was admitted to the

have been including non-members in his definition of the laity. Hall, Worlds of Wonder, 153. Cooper questioned lay opposition and also argued that the election was a measure not only of support for the Halfway Covenant but also of the ministry. Cooper, Tenacious of Their Liberties, 109, 242n44.

${ }^{49}$ First Church Records, 66; Felt, Ecclesiastical History, 2:443 250.

${ }^{50}$ Hill, History of the Old South, 119; Hill and Bigelow, eds., Historical Catalogue, 1, 226, 
covenant with the other wives in 1674 . First Church's decision about Pemberton was cited in Third Church's written defense of the wives admittance at that time.

Other than this case, the records of both First and Third Churches are silent with respect to the wives for the next three years. In June 1671, the new General Court declared that Third Church should be considered a church in good standing, and the new congregation continued to grow, though the acrimony between First and Third churches did not abate. ${ }^{51}$ Over the next four years, the membership of the new church would surpass the Second, or Old North, Church (the church of Increase and Cotton Mather). ${ }^{52}$ Though the wives of the founders were unable to join the covenant, a large number of women were among those who joined the new church in full communion during these years. ${ }^{53}$ The wives of the founders, barred from the Supper at First Church, continued to attend services and participate in the sacraments at the new church and do not seem to have actively pursued formal dismissions. Church membership, as we have seen, conferred two major benefits: participation in the sacraments and in church governance. Since women were never able to participate actively in governance, and since the dissenting wives were able to participate in the

${ }^{51}$ Nathaniel B. Shurtleff, ed., Records of the Governor and Company of the Massachusetts Bay in New England, vol. 4, pt. 2 (1854; repr., New York: AMS Press, 1968), 793.

52 Third Church had 130 members at the end of 1673, while Pope found that Second Church had only 121 full members. See Appendix C; and Pope, Half-Way Covenant, 220. The pace of the activity between First and Third may have slowed, too, because of disruptions caused by conflict with Indians in the build-up to King Philip's War. See Carol Berkin, First Generations: Women in Colonial America (New York: Hill and Wang, 1996), 45; Hutchinson, History of Massachusetts-Bay, 1:237, $241 n$.

${ }^{53}$ Twice as many women as men joined Third Church in full communion between 1669 and the end of 1674. Pope, Half-Way Covenant, 225. See also Appendix C. 
Supper in the new church despite their unresolved status, the only difference between the dissenting women's practical status in Third Church and the actual status of their church membership was the formality of signing the covenant. While the covenant had real meaning for Puritan church members, the lived experience of these women prior to joining the covenant with Third Church must have been very nearly identical to what it would be after they joined.

Almost three years later, however, the wives' formal status remained in limbo. At the end of June 1673 Third Church resumed their attempts to gain dismission for the wives "after a long silence." Their renewed efforts were perhaps prompted by Urian Oakes's election sermon in May, though records indicate that the colony's magistrates and church elders were also anxious to have the dispute resolved. Oakes was the pastor at nearby Cambridge and although he did not cite the Third Church dispute explicitly, he did admonish those who fomented disputes and "mischievous calumnities" in the colony and urged the people to put an end to these "moral evils."54 Following Oakes's sermon, the Third Church was "incouraged by Magistrates and Elders of the Countrey to make another Essay for peace." In a letter to First Church, Third Church's minister and ruling elder extended an appeal for the old church to forget past offences and for a renewed spirit of communion between the two churches. Thatcher and Edward Rainsford pleaded,

${ }^{54}$ Urian Oakes, "New England Pleaded With," excerpted in Third Church Narrative, 194-196. See also Mather, Magnalia, 2:114-118. 
let it be no offence to you that we receive those of you who desire it that have hitherto held Communion at the table of the Lord with us into our Communion, but grant your loving dismission unto them, neither let it be any offence for any of ours as they may desire it to come and partake with you in your neerest Communion, or of yours henceforth on the like occasion to sit downe at the Lords table with us.

The new church reasserted their hope for establishing regular relations and their sense of shared purpose with First Church, insisting that "we have all the same common cause viz the Congregationall way laid downe for substance in the Platforme of discipline, the same friends, enemies, hopes, feares, dangers, desires, imbarked in the same Commonwealth, and in hazard to be in the same Common woe, should god let loose an adversary against us." ${ }^{, 55}$ Adversaries indeed threatened the colony and the churches in coming months and years, but the two churches did not reconcile and have regular relations until 1682, when the Crown's efforts to impose toleration on the colony made solidarity more important than the grudge. ${ }^{56}$

First Church waited some two months to reply to Third Church's request for the wives' dismission. In this letter, the ministers of the old church asserted that they were not to blame for the discord between the churches. Their stance had not been simply to "impos[e] a silence," but to take a stand against "division and contention" by refusing to have relations with Third Church. The dissenters had been wrong to separate from First Church during "an houre of temptation," and First Church saw it as

${ }^{55}$ Thomas Thatcher and Edward Rainsford to First Church, 13 June 1673, in Third Church Narrative, 196-197.

${ }^{56}$ Hill, History of the Old South, 243-247; Mather, Magnalia, 2:312-313; Miller, Colony to Province, 134-142, 149. See also Edward Randolph to the Bishop of London, 29 May 1682, in Edward Randolph, ed. Robert Noxon Toppan, 3:178-180 (Boston: The Prince Society, 1899). 
an admission of wrongdoing that the new church was "asking earnestly againe and againe" for "forgiveness." As for the wives, First Church implied that they needed reminding of the issue; they discovered that the women were found "in our Church records to have desired a release from their Covenant ingagements." The old church declared the wives to have "upon their owne irregular choice gone out from us and from any further Authority of this Church," but stopped short of extending a formal release from the covenant. Perhaps they saw this as a way of avoiding the dismission issue indefinitely; if the wives were no longer subject to the authority of First Church, then the old church had no business issuing any dismission for them. The day after drafting this letter, the old church voted to send their ruling elder to meet with the wives and offer them a general dismission if they would "confesse their fault." Though the wives' answer was not recorded, they clearly refused. ${ }^{57}$ The cycle of confession and reconciliation was common in disciplinary cases, and the wives' refusal to admit fault was a clear sign that they had no interest in appeasing the church with which they had been at odds for so long, and also likely indicates that they did not trust the church elders to make good on a promise after failing to do so repeatedly.

In May 1674, a council of ministers met at the request of Third Church to advise them about resolving the membership status of the wives. The question put to the council was: "What is our duty towards those members of the Old church who were and still are secluded from communion with that church in the sacrament of the

\footnotetext{
${ }^{57}$ John Oxenbridge and James Allen to Third Church, 19 August 1673, in Third Church
} Narrative, 199-200. 
Lord's Supper, only because of their participation with us therein, and who also desire to join in church fellowship with us?"58 The wording of this question is perhaps important, because Third Church did not describe the women as those "who are desired to" join the fellowship. The language used in the council request indicates that the women's choice to join the new church was a necessary part of the argument for their release. If the requirements of their marriage covenants overwhelmed the women's individual covenants, they could have used the latter language. Stating that it was the women's desire indicates that the women's wishes as church members were to be considered and valued.

The council declared that Third Church was "and ought to be acknowledged, a true church of Christ, standing right in the order of communion of churches in all respects." Participation in the Lord's Supper at the new church, therefore, could not be considered an offence to any other church, and any church who disciplined its members for doing so would be violating "the rules and order of the communion of churches." Because the old church had not enacted any formal proceedings against the wives, the women could not be considered to be under censure, admonition, or excommunication even though they had been barred from communion; they were therefore still in good standing and eligible to join another church in good order. The women had done everything in their power to secure orderly dismissions ("there having been all due means used for their reconciliation to and dismission from the said

${ }^{58}$ Thomas Cobbett, council result, 28 May 1674, in Third Church Narrative, 203; Felt, Ecclesiastical History, 2:443. 
church unto that which they find more for their edification and consolation in the Lord"), and so the council concluded that "such members may joyne, and such a Church unto whome they desire to joyn may receive them into their fellowship without the transgression of any rule of Church order or any just offence given unto the church unto which they did belong." ${ }^{, 59}$ The council did not predicate any part of their decision upon a requirement that the women follow their husbands in worship, but instead acknowledged their rights as individual believers and church members to justice and freedom of conscience in worship.

In August 1674, the women petitioned Third Church for admission to membership. Based on the old church's assertion that the sisters no longer stood "in any memberly relation to them," the sisters asked Third Church to admit them into membership without a regular dismission from their previous covenant obligation. They summarized their efforts to obtain that dismission and asked Third Church to conclude that they could be admitted into membership in the new church where they had been receiving the sacrament with their husbands. They argued that they were "hopelesse for help from them [First Church], except wee would renounce communion with you which we cannot in Conscience do." ${ }^{60}$ The application for admission was accepted by Third Church and the wives were finally admitted into membership on October 16,1674 , some five years after their husbands formally established the new church and four years since the old church had first denied them communion.

\footnotetext{
${ }^{59}$ Thomas Cobbett, council result, 28 May 1674, in Third Church Narrative, 203-204.

${ }^{60}$ Dissenting wives to Third Church, 27 August 1674, in Third Church Narrative, 201.
} 
In the end, then, the wives never obtained the dismissions which they and Third Church sought for so many years. After five years of agitating for a formal and regular dismission, the wives finally covenanted with the church of their husbands; like their husbands, they never received formal dismissions from the old church. The founding of Third Church was, with the long-delayed addition of the founders' wives to the covenant, finally complete. 


\section{Conclusion}

\section{"Wee ly under the same rule" Competing Covenants}

The schism in First Church that resulted in Third Church's founding had its roots in disputes over theology, politics, and church government. The men of First and Third Churches were embroiled in controversies that had raged since the colony's settlement: the proper subjects of baptism, the authority of the congregation, the role of synods, and the relationship between the state and the churches. These disputes stemmed from disagreements over the application of congregational theory. The ensuing drama over the membership of the wives, however, had its source not in the application of congregational theory but in its essence. Women, like men, were subject to a series of interlocking and overlapping covenant obligations. The delicate balance between these covenants was complicated by the peculiar and contradictory status of women as both individually covenanted saints and as subordinates with no claim to autonomy. The women who were held hostage by First Church were wives of church members and were acting both as part of marital units and as individuals. ${ }^{1}$

${ }^{1}$ Although five women who did not have husbands in Third Church joined the wives in their final petition for admission, the women whose names appeared on previous petitions were all wives of dissenting brethren. Johanna Mason's husband joined Third Church in 1704, and Mary Norton was the widow of the Rev. John Norton. Elizabeth Beck, Sarah Bodeman, and Alice Harper seem to not have been joined by husbands in Third Church, and none of them had husbands who were signatories to any petitions. Names of the men who signed the covenant in 1669 , along with the names of the women found on all three of their petitions, can be found in Appendix B. Dissenting wives to Third Church, 27 August 1674, Third Church Narrative, in Hamilton Andrews Hill, ed., History of the Old South Church (Third Church) Boston, 1669-1884 (Boston: Houghton, Mifflin, 1890) [hereafter History of the Old South], 202; Hamilton Andrews Hill and George Frederick Bigelow, eds., An Historical Catalogue of the Old South Church (Third Church) Boston, 1669-1882 (Boston: David Clapp \& Son, 1883), 5-10. Mary Norton was evidently a staunch supporter of the new church and donated the land on which the meetinghouse was built. On the land donation, see Hill, History of the Old South, 128-153. 
This contradiction, and the tension among their covenants, created the circumstances that left the women's status unresolved for five years.

Married female church members were subject to two primary covenants: the marriage covenant, governed by the Fifth Commandment, in which they were subordinate to their husbands; and the church covenant, governed by the male elders and clergy. ${ }^{2}$ New England's visible saints were subordinate to their superiors, and a woman's autonomy was limited by subordination to male authorities both in the home and the meetinghouse. ${ }^{3}$ The tenets of her faith, however, provided no guide when her superiors disagreed. The confusion created by this disagreement allowed the Third Church wives to assert their spiritual autonomy and their individual rights as believers

${ }^{2}$ Laurel Thatcher Ulrich, Good Wives: Image and Reality in the Lives of Women in Northern New England, 1650-1750 (New York: Vintage, 1991), 6. While marriage was a civil contract, the relationship between husbands and wives was also a religious covenant and "submission to God and submission to one's husband were part of the same religious duty." See also Edmund S. Morgan, The Puritan Family: Religion and Domestic Relations in Seventeenth-Century New England (1944; New York: Harper \& Row, 1966), 29-32. The tension between women's duty to be obedient and their personal covenant with God was not uncommon; it had arisen earlier in Roger Williams's Providence, when a husband was censured for not allowing his wife to attend church "so oft as she was called for"; one church member lamented that the rule allowing "wives, and children, and servants" the freedom to attend church meetings according to their own consciences was never intended to "extend to the breach of any ordinance of God, such as the subjection of wives to their husbands." Another man replied that "if they should restrain their wives, etc., all the women in the country would cry out of them." John Winthrop, The Journal of John Winthrop, 1630-1649, ed. Richard S. Dunn, James Savage, and Laetitia Yeandle (Cambridge, MA: Belknap Press, 1996), 276-277. This issue also appeared in the colony of Virginia; in 1708, a court ruled that a Quaker, George Walker, was within his rights to prohibit his Anglican wife, Ann, from raising their children in her faith. Although hostilities existed between the authorities and the Quakers, "respect for a husband's authority was greater even than prejudice against heretics." Julia Cherry Spruill, Women's Life and Work in the Southern Colonies (1938; New York: W. W. Norton, 1972), 345.

${ }^{3}$ Anne S. Brown and David D. Hall, "Family Strategies and Religious Practice: Baptism and the Lord's Supper in Early New England," in Lived Religion in America: Toward a History of Practice, ed. David D. Hall, 41-68 (Princeton, NJ: Princeton University Press, 1997), 42; Carol Berkin, First Generations: Women in Colonial America (New York: Hill and Wang, 1996), 26. Male autonomy was limited too, but they had a voice in church affairs, could vote for church officers and on disciplinary cases, and seem to have had more opportunities and more sanction to question the authority of their superiors in the church. More research needs to be done on the power relationships between men within the church. 
by choosing to adhere to their covenant obligations to their husbands rather than with the church, and to do so not only out of obligation but also because of their own beliefs. Though they chose to follow their husbands and adhere to their covenant obligation to them, they did not rely on their husbands to speak for them. When the dissenting men completed the breach with First Church and established a new congregation, they no longer had the means to advocate for their wives within the meetinghouse. The women were able to advocate for themselves and obtain the help of a minister and a council because they were saints, not just wives.

Covenants enjoined mutual responsibilities on the parties involved, and the marriage covenant was no different. According to Samuel Willard, marriage entailed a four-fold mutual obligation: "Conjugal love," "A Special Care and Tenderness one of another," "A Mutual endeavour to promote each others Eternal Salvation," and "A joint Interest in governing the rest of their Family." Husbands were superior to wives; on this there was no disagreement. A wife was expected to submit to her husband's rule, to obey him and support him, to aid in his spiritual life, to encourage

${ }^{4}$ Samuel Willard, “Sermon CLXXVIII [July 27, 1703],” A Compleat Body of Divinity (1726; repr., New York: Johnson Reprint Corporation, 1969), 609. While this sermon was written some thirty years after the founding of Third Church, Willard (who succeeded Thatcher in the ministry at Third Church in 1678) provided the most thorough explication of the Fifth Commandment's application to marriage. Morgan found similar ideas in sermons by Willard, Thomas Thatcher, and John Oxenbridge. See Morgan, Puritan Family, 42. It is certainly possible that attitudes toward women and marriage changed during the intervening years, but if anything, male and female gender roles seem to have diverged and solidified in New England at the end of the seventeenth century. See C. Dallett Hemphill, "Women in Court: Sex-Role Differentiation in Salem, Massachusetts, 1636 to 1683," William and Mary Quarterly 39 (1982): 172-175; and Laurel Thatcher Ulrich, "Vertuous Women Found: New England Ministerial Literature, 1668-1735," American Quarterly 28 (1976): 37-40. James W. Jones notes that Compleat Body was "a bit out of date" when it was published, and had more in common with the theology of the seventeenth century than it did with the Great Awakening which "quickly washed over and ran on past it." Jones, The Shattered Synthesis: New England Puritanism before the Great Awakening (New Haven: Yale University Press, 1973), 55. 
his piety, and to endeavor to help him govern wisely. Though a husband was "to be acknowledged to hold a Superiority, which the Wife is practically to allow," he was also meant to govern her with wisdom and kindness. The hierarchal relationship in a marriage was different in quality and kind than the relationship between parents and children or between masters and servants. ${ }^{5}$

A wife's submission to her husband's authority did not mean that she abandoned her individual conscience. She should consult her husband in "every matter of weight; to take his Direction in things of common concern between them; and in things indifferent to chuse rather to gratify his Demands, than please her own Humours." ${ }^{, 6}$ A subordinate should not be blindly obedient, however, and if a superior should "advise, or Command one that is a Subject to him, any thing which is contrary to the revealed Will of God, he is to refuse to do it," because duty to God should override any other duty. There was, of course, a "duty of Compliance," but in that "a Wife certainly hath greater liberty of debating the Prudence of the thing." Implicit in these instructions is the idea that a woman had the ability to decide which commands may or may not be contrary to God's will and had the right to refuse a command from her husband. ${ }^{7}$ Had the wives of the dissenting brethren agreed with First Church that

\footnotetext{
${ }^{5}$ Willard, "Sermon CLXXVIII," Body of Divinity, 610, 612. The difference between the husband-wife relationship and the parent-child relationship was subscribed to in England before the migration as well, as described in Thomas Gataker, A Good Wife Gods Gift: And, A Wife Indeed (London: John Haviland for Fulke Clifton, 1623), STC ( $2^{\text {nd }}$ ed.) 11659, p. 5.

${ }^{6}$ Willard, "Sermon CLXXVIII," Body of Divinity, 612.

${ }^{7}$ For more on equality and Puritan marriage, see John Demos, A Little Commonwealth: Family Life in Plymouth Colony (London: Oxford University Press, 1970), chapter 5; Morgan, Puritan Family, chapter 2; Ulrich, Good Wives, 106-110; Berkin, First Generations, 31-32; Kenneth Charlton, Women,
} 
the schism was a "moral evil" and that the dissenters were "disturbers of the Church," they would have been within their technical rights to stay in First Church. The old church had in fact been implicitly encouraging women to violate their marital obligation by refusing to grant the wives' dismissions. ${ }^{8}$

If the women chose willingly to follow their husbands, not just out of obligation to their marriage covenant but also because they agreed with the action, they may have been convinced to do so by Davenport's opposition to the Halfway Covenant. That the women followed their husbands to a church which advocated extending baptism, and that they chose to adhere to their marital covenant instead of their church covenant, plausibly indicates that the wives viewed family as a more important social institution than the church. For men, the choice was one and the same: Once they had left First Church, choosing their consciences over church order, getting dismissions for wives and getting them into Third Church would preserve both church order and family order. We cannot know the extent to which the women's consciences played a role in their desire to join Third Church, but their choice was

Religion and Education in Early Modern England (London: Routledge, 1999), 18-19, 33-48; and James T. Johnson, "The Covenant Idea and the Puritan View of Marriage," Journal of the History of Ideas 32 (1971): 107-118. My intent is not to join in the debate over whether Puritan ideas of marriage constituted a break with previous ideals or practice, but only to argue that there was an allowance made for female autonomy of thought and intention even within a hierarchical marriage. On the debate, see for example Kathleen M. Davies, "The Sacred Condition of Equality: How Original Were Puritan Doctrines of Marriage?" Social History 2 (1977): 563-580; and Christine Peters, Patterns of Piety: Women, Gender, and Religion in Late Medieval and Reformation England (Cambridge, UK: Cambridge University Press, 2003), chapter 13.

${ }^{8}$ Third Church Narrative, 43; John Allin and John Elliot to churches at Salem, Linn, and Ipswich, 2 April 1669, in Third Church Narrative, 55. At least one well-known Puritan dissenter seems to not have been followed by his wife: Roger Williams would not join in family devotions with his wife because she continued to attend Salem Church. Joseph B. Felt, The Ecclesiastical History of New England; Comprising not only Religious, but also Moral, and other Relations (Boston: Congregational Library Association, 1862), 1:295. 
likely inextricably linked to their desire to join their husbands. Still, they clearly chose the preservation of family order, their husbands' authority, and their own spiritual health over the preservation of church order and ministerial authority. Their covenant with their husbands trumped their covenant with First Church.

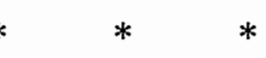

Within the confines of these interlocking patriarchal covenants, women were able to exert indirect influence over the church. Though they could not vote in church matters or speak publicly in church meetings, women could use private power to influence affairs that would seem to be outside of their sphere. Linda Kerber has warned that there is a danger in setting up a "private/public dichotomy" and assuming that only the former was the province of women. ${ }^{9}$ While the doctrine of spheres (originally coined to describe nineteenth-century conditions) ${ }^{10}$ has been a useful construct in the development of women's history, it is anachronistic and not particularly productive to assign particular spheres to women in seventeenth-century New England. Public places such as the courtroom were not exclusively male domains, and women could be found laboring in the fields and the marketplace as well as the home. In church life, too, women extended their influence into the public realm. Women were assigned to the "more private aspects of Puritan devotion"-

\footnotetext{
${ }^{9}$ Linda K. Kerber, "Separate Spheres, Female Worlds, Woman's Place: The Rhetoric of Women's History," Journal of American History 75 (1988): 9-39.

${ }^{10}$ See, for example, Barbara Welter, "The Cult of True Womanhood: 1820-1860," American Quarterly 18 (1966): 151-174.
} 
personal and maternal piety—and historians have often relegated them to only these, but there is also evidence that women were also public actors in the cause of their faith. ${ }^{11}$

Female congregants could not vote in church matters, but they did exert influence over both their husbands and their ministers using indirect means. Women's public speech was constrained, but they could use private speech to wield influence both in their homes and in their communities. Ministers depended on women, who constituted the majority of their congregations, to support them in the community; gossip networks could elevate or destroy a minister's reputation. Women may have influenced doctrine, though this is difficult to determine in cases that did not result in heresy charges. There is also evidence that women exerted pressure on the voting members of the congregations, particularly to advocate for new meetinghouses. As communities expanded, the burden of traveling to the meetinghouse was doubly burdensome for women because of the physical limitations of pregnancy, recovery from childbirth, and care of small children. ${ }^{12}$ Some women even took matters into their own hands when they could not prevail on the male authorities. The most striking case is Chebacco's effort to build its own meetinghouse in 1677. Travel to the nearest meetinghouse in Ipswich was prohibitive and the inhabitants petitioned for

${ }^{11}$ Mark A. Peterson, The Price of Redemption: The Spiritual Economy of Puritan New England (Stanford, CA: Stanford University Press, 1997), 93.

${ }^{12}$ Amanda Porterfield, "Women's Attraction to Puritanism," Church History 60 (1991): 199_ 200; Berkin, First Generations, 41-42; Ulrich, Good Wives, 216-217; Mary Maples Dunn, "Saints and Sisters: Congregational and Quaker Women in the Early Colonial Period," in "Women and Religion," special issue, American Quarterly 30 (1978): 585-588. 
their own church. Ipswich resisted their petition, and while the men negotiated with civil authorities, the women conspired "without the knowledge of theire husbands" to have the meetinghouse built. Though the women's ringleaders were fined for their insubordination, the meetinghouse stood and the town was granted permission to call a minister soon after. ${ }^{13}$

Women's individual membership status, their ability to question their husbands' directives, the knowledge of Puritan doctrine required for membership, their concern for the spiritual welfare of children, their ability to exercise indirect influence, and the actual pressure that women are known to have exerted on male authorities all indicate that the dissenting wives could have been actively involved in both supporting the dispute with First Church and in sustaining the dissent. They were not passively obedient but acted as partners with their husbands and the minister, Thomas Thatcher, in efforts to secure their dismissions. They argued their case to First Church's ministers and elders, presented letters and petitions in their own names, and defied ministerial orders by attending the new church with their husbands.

Though the women were ensnared by their defiance, the only punishment inflicted by the old church—denying them communion-had no teeth. It prevented them from communion only with First Church, something they did not want anyway. ${ }^{14}$ The

${ }^{13}$ Ulrich, Good Wives, 218-219; Lyle Koehler, A Search for Power: The "Weaker Sex" in Seventeenth-Century New England (Urbana: University of Illinois Press, 1980), 356; Records of Chebacco Parish, quoted in Ulrich, Good Wives, 218-219.

${ }^{14}$ It is possible that they still may have suffered some "social disabilities" in the community among those who continued in membership at First Church, but there is no evidence of this in the extant records and the number of intermarriages between First and Third Church members, including those 
women received the Supper at Third Church, and were also eligible to partake in the many churches that recognized the new church. First Church's denial of communion would have constituted a negligible spiritual or social injury, since First Church stood nearly alone in their rejection of Third Church and had lost legitimacy in the eyes of Third's congregants. Time and again First Church stopped short of censuring the women, which would have done real damage by preventing them from joining any other church until First Church declared the dispute resolved.

The dissenting women were not punished for their actions because, unlike the Chebacco women, the women of Third Church navigated their way through the dispute without violating prevailing standards for women's behavior and for the most part without defying male authorities. Though they submitted petitions and negotiated with male authorities, they never actually seem to have spoken aloud in church meetings. Instead, they spoke and voted with their feet. Even when they submitted individual letters and when they took communion at the new church, they were not criticized for improper female behavior. The establishment of the new church had already been decided by male authorities before attention turned to the women; First Church had no standing for preventing them from joining a church that was in good standing, according to neighboring churches and the civil authorities, and was the place where their husbands worshipped. 
It is possible that the women's efforts to join their husbands, which supported the family hierarchy, and the emphasis they placed on family as the dominant social institution overrode any implication of impropriety. It is equally likely that women engaged in similar activities in other churches, that active disagreement with ministers was allowed in private conference if not in public questioning, and that women's lives in the church were not as restricted as the theologians' assertions might seem to indicate. Carol Karlsen has argued that by 1660 female dissenters had been branded as heretics or witches, which silenced women and gave their religious lives "a decidedly submissive character." 15 This case shows that women had not been silenced. The story of the Third Church women is not a parable of either progress or declension and does not necessarily indicate an increase or decrease in women's power. What it does demonstrate is that they had power in the church and the ability to act.

The wives' methods for negotiating their release from the First Church covenant were necessitated by limitations placed on their activities as church members, which prevented them from utilizing direct, public confrontation. The prohibition on women's public speech and on their ability to participate in church government through voting in church affairs made their membership less full than that of men who had joined the covenant in full communion. The ministry and laity in New England worried that implementation of the Halfway Covenant, which provided

\footnotetext{
${ }^{15}$ Carol Karlsen, The Devil in the Shape of a Woman: Witchcraft in Colonial New England (1987; New York: W. W. Norton, 1998), 197.
} 
access to baptism for the children of unregenerate members, could corrupt the purity of the church. Halfway membership, however, did not change the requirement that all members demonstrate evidence of saving grace before sitting down at the Lord's Table or voting in church matters: The Supper and church government—and therefore the purity of the church-remained protected by the Halfway Covenant. The privileges afforded by visible sainthood were contingent upon not only the believer's relationship with God and the covenant, but also upon their gender. Women could not access the full privileges that Puritan theology afforded to male regenerate members, and church membership in Puritan New England was therefore not a dichotomous status even before the Halfway Covenant created a new category of transitional membership. In this context, the implications of the Halfway Covenant's "innovation" are much less innovative than the open communion offered by Solomon Stoddard at the turn of the eighteenth century. ${ }^{16}$ Allowing the unregenerate to participate in the Lord's Supper was a real deviation from the founders' ideals; in comparison, the threat represented by Halfway membership was a chimera. Rather than a revolution in Puritan practice, Halfway membership added another category to the multiple forms of membership that already existed.

The dissenting wives' activities within the church were constrained by their status as women, but they were able to advocate for themselves without violating gender norms: They did not speak publicly in the church and they did not make

\footnotetext{
${ }^{16}$ Perry Miller, The New England Mind: From Colony to Province (1953; Boston: Beacon Press, 1961), 226-235.
} 
theological arguments. They did not try to circumvent male authority, but when forced to chose between competing allegiances and competing sets of rules to which they were expected to conform, they acted in the service of some male authorities (their husbands) by defying others (the officers of First Church). The story of Third Church's founding shows that women were not only actors in the private aspects of religion in Boston; they were public actors. Women's roles as wives and their roles as church members could and did conflict; a theology that emphasized individual spiritual autonomy allowed them to choose between these conflicting authorities and act in their service of their consciences. Puritan New England was a patriarchal society and women's public roles were constrained by gender-role expectations. But women also had agency — to read, to write, to think, and to act as church memberswhich made the patriarchy negotiable to some degree, even though their agency was always mediated through male authorities. Within the bounds of expectations and hierarchy, the women of Third Church acted in public ways to assert their rights as wives, as saints, and as members of the community. They did this by acting within the boundaries, not by crossing them. 


\section{Sources Consulted}

\section{Primary Sources}

The Book of the General Lawes and Libertyes Concerning the Inhabitants of the Massachusets. 1648; facsimile edition, Cambridge University Press, 1929.

Cotton, John. Certain Queries Tending to Accommodation and Communion of Presbyterian \& Congregationall Churches. London: M.S. for John Allen, 1654. Wing C6416.

. A Coppy of a Letter of Mr. Cotton of Boston, in New England, sent in answer of certaine Objections made against their Discipline and Orders there, directed to a Friend. With the Questions propounded to such as are admitted to the Church-fellowship, and the Covenant it Selfe. [London], 1641. Wing C6422.

. The Covenant of Gods free Grace, Most sweetly unfolded, and comfortably applied to a disquieted Soul, from that Text of 2 Sam. 23 Ver. 5. London: M.S. for John Hancock, 1645. Wing C6424.

. The Keyes Of the Kingdom of Heaven, and Power thereof, according to the Word of God. London: M. Simmons for Henry Overton, 1644. Wing C6439.

Milk For Babes. Drawn Out of the Breasts of both Testaments. Chiefly, for the spirituall nourishment of Boston Babes in either England: But may be of like use for any Children. London: J. Coe for Henry Overton, 1646. Wing C6443.

Singing of Psalms a Gospel-Ordinance. London: M.S. for Hannah Allen and John Rothwell, 1647. Wing ( $2^{\text {nd }}$ ed.) C6456.

- Sixteene Questions of Serious and Necessary Consequence, Propounded unto Mr. John Cotton of Boston in New-England, Together With His Answers to each Question. London: E.P. for Edward Blackmore, 1644. Wing S3928.

- Spirituall Milk for Boston Babes in either England. Drawn out of the Breasts of both Testaments, for their soules nourishment: But may be of like use for any Children. London: Henry Cripps, 1657. Wing ( $2^{\text {nd }}$ ed.) C6462A.

The True Constitution Of A particular visible Church, proved by Scripture. Wherein is briefly Demonstrated by Questions and Answers what Officers, 
Worship, and Government Christ hath ordained in his Church. London: Samuel Satterthwaite, 1642 . Wing $\left(2^{\text {nd }}\right.$ ed) C6468.

. The Way of the Churches of Christ in New-England. Or the Way of Churches walking in Brotherly equalitie, or co-ordination, without Subjection of one Church to another. London: Matthew Simmons, 1645. Wing ( $2^{\text {nd }} \mathrm{ed}$.) C6471.

Danforth, Samuel. A Brief Recognition of New-Englands Errand into the Wilderness; Made in the Audience of the General Assembly of the Massachusets Colony, at Boston in N.E. on the $11^{\text {th }}$ of the third Moneth, 1670, being the Day of Election there. Cambridge, MA: S. G. and M. J., 1671. Evans 160, Wing ( $2^{\text {nd }}$ ed.) D175.

Davenport, John. An Answer of the Elders of the Severall Churches in New-England unto Nine Positions.... Written in the Yeer, 1639. London: T. P. and M. S. for Benjamin Allen, 1643. Wing ( $2^{\text {nd }}$ ed.) M1270.

- Another Essay For Investigation of the Truth, In Answer To Two Questions, concerning I. The Subject of Baptism. II. The Consociation of Churches. Cambridge, MA: Samuel Green and Marmaduke Johnson, 1663. Wing D356. . A Catechism Containing the Chief Heads of Christian Religion. Published, at the desire, and for the use of the Church of Christ at New-Haven. London: John Brudenell, 1659. Wing D357.

. The Profession of Faith of That Reverend and worthy Divine. London: John Hancock, 1642. Wing ( $2^{\text {nd }}$ ed.) D364.

Fiske, John. The Notebook of the Reverend John Fiske, 1644-1675. Edited by Robert G. Pope. Salem, MA: Essex Institute, 1974.

Gataker, Thomas. A Good Wife Gods Gift: And, A Wife Indeed. London: John Haviland for Fulke Clifton, 1623. STC ( $2^{\text {nd }}$ ed.) 11659.

Hall, David D., ed. The Antinomian Controversy, 1636-1638: A Documentary History. $2^{\text {nd }}$ ed. Durham, NC: Duke University Press, 1990.

Hill, Hamilton Andrews. History of the Old South Church (Third Church) Boston, 1669-1884. Vol. 1. Boston: Houghton Mifflin, 1890.

Hill, Hamilton Andrews, and George Frederick Bigelow, eds. An Historical Catalogue of the Old South Church (Third Church) Boston, 1669-1882. Boston: David Clapp \& Son, 1883. 
Hoadly, Charles J., ed. Records of the Colony or Jurisdiction of New Haven from May, 1653, to the Union. Together with the New Haven Code of 1656. Hartford, CT: Case, Lockwood and Company, 1858.

Hooker, Thomas. A Survey of the Summe of Church-Discipline. 1648. Facsimile edition. New York: Arno Press, 1972.

Hubbard, William. A General History of New England from the Discovery to MDCLXXX. [1680]. Collections of the Massachusetts Historical Society, $2^{\text {nd }}$ series, 5. 1815. Repr., New York: Arno Press, 1972.

Hull, John. Memoir and Diaries of John Hill [Hull], Mint-master and Treasurer of the Colony of Massachusetts Bay. 1857. Repr., New York: AMS Press, 1982.

Hutchinson, Thomas. The History of the Colony and Province of Massachusetts-Bay. Vol. 1. Ed. Lawrence Shaw Mayo. 1764. Cambridge, MA: Harvard University Press, 1936.

Lechford, Thomas. Plain Dealing: Or, Newes From New-England. London: W. E. and I. G. for Nath. Butter, 1642. Wing L810.

Mather, Cotton. An Epistle To the Christian Indians, Giving them A Short Account, of what the English Desire them to Know and to Do, in order to their Happiness. Boston: Bartholomew Green and John Allen, 1700. Wing M1178.

- A Family Well-Ordered. Or, An Essay To Render Parents and Children Happy in one another. Handling Two very Important Cases. Boston: B. Green \& J. Allen for Michael Perry, 1699. Wing M1109.

- The Negro Christianized. An Essay to Excite and Assist that Good Work, The Instruction of Negro-Servants in Christianity. Boston: B. Green, 1706. Evans 1262.

- Magnalia Christi Americana; or, The Ecclesiastical History of New-England. 2 vols. 1702; Hartford, CT: Silas Andrus \& Son, 1853.

Mather, Richard. Church-Government and Church-Covenant Discussed. In an Answer of the Elders in the severall Churches in New-England To two and thirty Questions, sent over to them by divers Ministers in England, to declare their judgments therein. London: R. O. and G. D. for Benjamin Allen, 1643. Wing ( $2^{\text {nd }}$ ed.) M1270.

A Defence of the Answer and Arguments of the Synod Met at Boston in the Year 1662. Concerning the Subject of Baptism, and Consociation of Churches. 
Cambridge, MA: S. Green and M. Johnson for Hezekiah Usher, 1664. Wing M1271.

. A Disputation Concerning Church-Members and their Children. London: J. Hayes for Samuel Thomson, 1659. Wing W1271A.

A Platform of Church Discipline Gathered out of the Word of God; And Agreed upon by the Elders and Messengers of the Churches Assembled in the Synod at Cambridge in New England. 1649. Boston: John Foster, 1680. Wing P2400, Evans 282.

Oakes, Urian. New-England Pleaded With, and pressed to consider the things which concern her peace. Cambridge, MA: Samuel Green, 1673. Wing O21, Evans 180 .

Pierce, Richard D., ed. The Records of the First Church in Boston 1630-1868. Publications of the Colonial Society of Massachusetts 39. Boston: Published by the Society, 1961.

- The Records of the First Church in Salem, Massachusetts 1629-1736. Salem, MA: Essex Institute, 1974.

Plymouth Church Records 1620-1859. Publications of the Colonial Society of Massachusetts 22. Collections. Boston: The Colonial Society of Massachusetts, 1920.

Propositions Concerning the Subject of Baptism and Consociation of Churches, Collected and Confirmed out of the Word of God by a Synod of Elders and Messengers of the Churches in Massachusets-Colony in New-England. Assembled at Boston, according to Appointment of the Honoured General Court, In the Year 1662. Cambridge, MA: S. G. for Hezekiah Usher, 1662. Evans 68, Wing ( $2^{\text {nd }}$ ed.) M2292.

Randolph, Edward. Edward Randolph to the Bishop of London, May 29, 1682. In Edward Randolph, ed. Robert Noxon Toppan, 3:178-180 (Boston: The Prince Society, 1899).

Records of the First Church at Dorchester in New England 1636-1734. Boston: George H. Ellis, 1891.

A Report of the Record Commissioners of the City of Boston, containing the Boston Records from 1660 to 1701. Seventh Report of the Record Commissioners. Boston Town Records 7. Boston: Rockwell and Churchill, 1881. 
Rowlandson, Mary. The Soveraignty \& Goodness of God, Together, With the Faithfulness of His Promises Displayed; Being a Narrative Of the Captivity and Restoration of Mrs. Mary Rowlandson. Cambridge, MA: Samuel Green, 1682. Wing ( $2^{\text {nd }}$ ed.) R2093, Evans 332.

Selement, George, and Bruce C. Woolley. Thomas Shepard's "Confessions." Publications of the Colonial Society of Massachusetts. Collections 58. Boston: The Society, 1981.

Shepard, Thomas. God's Plot: Puritan Spirituality in Thomas Shepard's Cambridge. Edited by Michael McGiffert. Amhurst: University of Massachusetts Press, 1994.

- The Parable of the Ten Virgins Opened \& Applied. 1660. Repr., [London]: Jonathan Mitchell, 1695.

Shurtleff, Nathaniel B., ed. Records of the Governor and Company of the Massachusetts Bay in New England. Vol. 4, pt. 2. 1661-1674. Boston: William White, Printer to the Commonwealth, 1854. Repr., NY: AMS Press, 1968.

Walker, Williston. The Creeds and Platforms of Congregationalism. 1893. Cleveland, OH: United Church Press, 1991.

Willard, Samuel. The Character Of a Good Ruler. Boston: Benjamin Harris for Michael Perry, 1694. Wing W2270.

. A Compleat Body of Divinity. 1726. Facsimile edition. New York: Johnson Reprint Corporation, 1969.

Winthrop, John. The Journal of John Winthrop, 1630-1649. Edited by Richard S. Dunn, James Savage, and Laetitia Yeandle. Cambridge, MA: Belknap Press, 1996.

. A Modell of Christian Charity. 1630. In The Puritans: A Sourcebook of Their Writings, ed. Perry Miller and Thomas H. Johnson, 1:194-199. 1938. New York: Harper Torchbooks, 1963. 


\section{Secondary Sources}

Anderson, Virginia DeJohn. New England's Generation: The Great Migration and the Formation of Society and Culture in the Seventeenth Century. Cambridge, UK: Cambridge University Press, 1991.

Archer, Richard. Fissures in the Rock: New England in the Seventeenth Century. Hanover, NH: University Press of New England, 2001.

Bacon, Margaret H. The Quiet Rebels: The Story of Quakers in America. New York: Basic Books, 1969.

Bailyn, Bernard. The New England Merchants in the Seventeenth Century. Cambridge, MA: Harvard University Press, 1955.

Barker-Benfield, Ben. "Anne Hutchinson and the Puritan Attitude toward Women." Feminist Studies 1 (1972): 65-96.

Battis, Emery. Saints and Sectaries: Anne Hutchinson and the Antinomian Controversy in the Massachusetts Bay Colony. Chapel Hill: University of North Carolina Press, 1962.

Beales, Ross W., Jr. "The Half-Way Covenant and Religious Scrupulosity: The First Church of Dorchester, Massachusetts, as a Test Case." William and Mary Quarterly 31 (1974): 465-480.

Bercovitch, Sacvan. The American Jeremiad. Madison: The University of Wisconsin Press, 1978.

Berkin, Carol. First Generations: Women in Colonial America. New York: Hill and Wang, 1996.

Bilhartz, Terry D. "Sex and the Second Great Awakening: The Feminization of American Religion Reconsidered." In Vandermeer and Swierenga, Belief and Behavior, 117-135.

Boydston, Jeanne. Home and Work: Housework, Wages, and the Ideology of Labor in the Early Republic. New York: Oxford University Press, 1990.

Boyer, Paul, and Stephen Nissenbaum. Salem Possessed: The Social Origins of Witchcraft. Cambridge, MA: Harvard University Press, 1974. 
Braude, Anne. "Women's History Is American Religious History." In Retelling U.S. Religious History, edited by Thomas A. Tweed, 87-107. Berkeley: University of California Press, 1997.

Breen, Timothy H. "Who Governs: The Town Franchise in Seventeenth-Century Massachusetts." William and Mary Quarterly 27 (1970): 460-474.

Breen, Timothy H., and Stephen Foster. "The Puritans' Greatest Achievement: A Study of Social Cohesion in Seventeenth-Century Massachusetts." Journal of American History 60 (1973): 5-22.

Brekus, Catherine A., ed. The Religious History of American Women: Reimagining the Past. Chapel Hill: University of North Carolina Press, 2007.

Bremer, Francis J. The Puritan Experiment: New England Society from Bradford to Edwards. Hanover, NH: University Press of New England, 1995.

. Shaping New Englands: Puritan Clergymen in Seventeenth-Century England and New England. New York: Twayne Publishers, 1994.

Brown, B. Katherine. "The Controversy over the Franchise in Puritan Massachusetts, 1954 to 1974." William and Mary Quarterly 33 (1976): 212-241.

_. "Freemanship in Puritan Massachusetts." American Historical Review 59 (1954): 865-883.

Brown, David C. "The Keys of the Kingdom: Excommunication in Colonial Massachusetts." New England Quarterly 67 (1994): 531-566.

Brown, Kathleen M. Good Wives, Nasty Wenches, and Anxious Patriarchs: Gender, Race, and Power in Colonial Virginia. Chapel Hill: University of North Carolina Press, 1996.

Butler, Jon. Awash in a Sea of Faith: Christianizing the American People. Cambridge, MA: Harvard University Press, 1990.

- "Magic, Astrology, and the Early American Religious Heritage, 1600-1760." American Historical Review 84 (1979): 317-346.

Butts, Francis T. "The Myth of Perry Miller." American Historical Review 87 (1982): 665-694.

Calder, Isabel M. "John Cotton and the New Haven Colony." New England Quarterly 3 (1930): 82-94. 
Caldwell, Patricia. The Puritan Conversion Narrative: The Beginnings of American Expression. Cambridge: Cambridge University Press, 1983.

Charlton, Kenneth. Women, Religion and Education in Early Modern England. London: Routledge, 1999.

Cohen, Charles Lloyd. God's Caress: The Psychology of Puritan Religious Experience. New York: Oxford University Press, 1986.

_- "The Post-Puritan Paradigm of Early American Religious History." William and Mary Quarterly 54 (1997): 695-722.

Collinson, Patrick. The Elizabethan Puritan Movement. Oxford: Clarendon Press, 1967.

Comi, Dana Rose. "'In the Shade of Solitude': The Mind of New England Women, 1630-1805." PhD diss., Brandeis University, 2003.

Cooper, James F., Jr. Tenacious of Their Liberties: The Congregationalists in Colonial Massachusetts. Oxford, U.K.: Oxford University Press, 1999.

Crane, Elaine Forman. Ebb Tide in New England: Women, Seaports, and Social Change 1630-1800. Boston: Northeastern University Press, 1998.

Crawford, Patricia. Women and Religion in England, 1500-1720. London: Routledge, 1996.

Davies, Kathleen M. "The Sacred Condition of Equality: How Original Were Puritan Doctrines of Marriage?" Social History 2 (1977): 563-580.

Dayton, Cornelia Hughes. Women before the Bar: Gender, Law, and Society in Connecticut, 1639-1789. Chapel Hill: University of North Carolina Press, 1995.

Delbanco, Andrew. The Puritan Ordeal. Cambridge, MA: Harvard University Press, 1989.

Demos, John Putnam. Entertaining Satan: Witchcraft and the Culture of Early New England. Oxford: Oxford University Press, 1982.

A Little Commonwealth: Family Life in Plymouth Colony. London: Oxford University Press, 1970.

. The Unredeemed Captive: A Family Story From Early America. New York: Vintage, 1994. 
Dexter, Henry Martyn. The Congregationalism of the Last Three Hundred Years. New York: Harper and Brothers, 1880.

Dinkin, Robert J. "Seating the Meeting House in Early Massachusetts." New England Quarterly 43 (1970): 450-464.

Ditmore, Michael G. "Preparation and Confession: Reconsidering Edmund S. Morgan's Visible Saints.” New England Quarterly 67 (1994): 298-319.

Douglas, James. "The Status of Women in New England and New France." Bulletin of the Departments of History and of Political and Economic Science in Queen's University, Kingston, Ontario, Canada, no. 3 (1912): 1-16.

Dunn, Mary Maples. "Saints and Sisters: Congregational and Quaker Women in the Early Colonial Period." In "Women and Religion." Special issue, American Quarterly 30 (1978): 582-601.

Durston, Christopher, and Jacqueline Eales, eds. The Culture of English Puritanism, 1560-1700. New York: St. Martin's Press, 1996.

Elliott, Emory B. Power and the Pulpit in Puritan New England. Princeton, NJ: Princeton University Press, 1975.

Ellis, George E. History of the First Church in Boston, 1630-1880. Boston: Hall and Whiting, 1881.

Emerson, William. An Historical Sketch of the First Church in Boston, From Its Formation to the Present Period. Boston: Munroe \& Francis, 1812.

Felt, Joseph B. The Ecclesiastical History of New England; Comprising not only Religious, but also Moral, and other Relations. 2 vols. Boston: Congregational Library Association, 1862.

Fitzgerald, Monica DiCataldo. "Wicked Hearts and Wayward Walking: Gender, Religion, and Identity in Early New England." PhD diss., University of California, Davis, 2005.

"Forum: Salem Repossessed." William and Mary Quarterly 65 (2008): 391-534.

Foster, Stephen. The Long Argument: English Puritanism and the Shaping of New England Culture, 1570-1700. Chapel Hill: University of North Carolina Press, 1991.

- "The Massachusetts Franchise in the Seventeenth Century." William and Mary Quarterly 24 (1967): 613-623. 
- Their Solitary Way: The Puritan Social Ethic in the First Century of Settlement in New England. New Haven, CT: Yale University Press, 1971.

Goen, C. C. Revivalism and Separatism in New England, 1740-1800: Strict Congregationalists and Separate Baptists in the Great Awakening. New Haven, CT: Yale University Press, 1962.

Greven, Philip J., Jr. Four Generations: Population, Land, and Family in Colonial Andover, Massachusetts. Ithaca, NY: Cornell University Press, 1970.

Gura, Philip F. A Glimpse of Sion's Glory: Puritan Radicalism in New England, 1620-1660. Middletown, CT: Wesleyan University Press, 1984.

Hall, David D. The Faithful Shepherd: A History of the New England Ministry in the Seventeenth Century. Cambridge, MA: Harvard University Press, 2006.

- Lived Religion in America: Toward a History of Practice. Princeton, NJ: Princeton University Press, 1997.

Worlds of Wonder, Days of Judgment: Popular Religious Belief in Early New England. Cambridge, MA: Harvard University Press, 1989.

Hall, Michael G. The Last American Puritan: The Life of Increase Mather. Middletown, CT: Wesleyan University Press, 1988.

Hambrick-Stowe, Charles E. The Practice of Piety: Puritan Devotional Disciplines in Seventeenth-Century New England. Chapel Hill: University of North Carolina Press, 1982.

Haskins, George Lee. Law and Authority in Early Massachusetts: A Study in Tradition and Design. New York: MacMillan, 1960.

Hemphill, C. Dallett. "Women in Court: Sex-Role Differentiation in Salem, Massachusetts, 1636 to 1683." William and Mary Quarterly 39 (1982): 164175 .

[Hill, Hamilton Andrews.] History of the Old South Church of Boston. Boston: Published for the benefit of the Old South fund, 1886.

Hochstetler, Laurie. "Sacred Rites: Religious Rituals and the Transformation of American Puritanism." PhD diss., University of Virginia, 2007.

Holifield, E. Brooks. The Covenant Sealed: The Development of Puritan Sacramental Theology in Old and New England, 1570-1720. New Haven, CT: Yale University Press, 1974. 
" "On Toleration in Massachusetts." Church History 38 (1969): 188-200.

- "Peace, Conflict, and Ritual in Puritan Congregations." Journal of Interdisciplinary History 23 (1993): 551-570.

Holliday, Carl. Women's Life in Colonial Days. 1922. New York: Frederick Ungar Publishing, 1960.

Ingram, Martin. "Puritans and the Church Courts, 1560-1640." In The Culture of English Puritanism, 1560-1700, edited by Christopher Durston and Jacqueline Eales, 58-91. New York: St. Martin's, 1996.

Irwin, Joyce L., ed. Womanhood in Radical Protestantism, 1525-1675. New York: The Edwin Mellen Press, 1979.

James, Janet Wilson, ed. Women in American Religion. Philadelphia: University of Pennsylvania Press, 1980.

Johnson, James T. "The Covenant Idea and the Puritan View of Marriage." Journal of the History of Ideas 32 (1971): 107-118.

Jones, James W. The Shattered Synthesis: New England Puritanism before the Great Awakening. New Haven, CT: Yale University Press, 1973.

Judd, Sylvester. History of Hadley. Springfield, MA: H. R. Huntting \& Company, 1905.

Juster, Susan. Disorderly Women: Sexual Politics and Evangelicalism in Revolutionary New England. Ithaca, NY: Cornell University Press, 1994.

Kamensky, Jane. Governing the Tongue: The Politics of Speech in Early New England. New York: Oxford University Press, 1997.

Karlsen, Carol. The Devil in the Shape of a Woman: Witchcraft in Colonial New England. 1987. New York: W. W. Norton, 1997.

Kerber, Linda K. "Separate Spheres, Female Worlds, Woman's Place: The Rhetoric of Women's History." Journal of American History 75 (1988): 9-39.

Kibbey, Ann. "Mutations of the Supernatural: Witchcraft, Remarkable Providences, and the Power of Puritan Men." American Quarterly 34 (1982): 125-148.

Kingdon, Robert M. "Protestant Parishes in the Old World and the New: The Cases of Geneva and Boston." Church History 48 (1979): 290-304. 
Knight, Janice. Orthodoxies in Massachusetts: Rereading American Puritanism.

Cambridge, MA: Harvard University Press, 1994.

Kobrin, David. "The Expansion of the Visible Church in New England: 1629-1650." Church History 36 (1967): 189-209.

Koehler, Lyle. "The Case of the American Jezebels: Anne Hutchinson and Female Agitation during the Years of Antinomian Turmoil, 1636-1640." William and Mary Quarterly 31 (1974): 55-78.

A Search for Power: The "Weaker Sex" in Seventeenth-Century New England. Urbana: University of Illinois Press, 1980.

Lambert, Frank. The Founding Fathers and the Place of Religion in America. Princeton, NJ: Princeton University Press, 2003.

LaPlante, Eve. American Jezebel: The Uncommon Life of Anne Hutchinson, the Woman Who Defied the Puritans. New York: HarperSanFrancisco, 2005.

Lerner, Gerda. The Creation of Feminist Consciousness: From the Middle Ages to Eighteen-seventy. New York: Oxford University Press, 1993.

Lewis, Alonzo, and James R. Newhall. History of Lynn, Essex County, Massachusetts: Including Lynnfield, Saugus, Swampscot, and Nahant. Boston: John L. Shorey, 1865.

Lindenauer, Leslie J. Piety and Power: Gender and Religious Culture in the American Colonies, 1630-1700. New York: Routledge, 2001.

Lockridge, Kenneth. Literacy in Colonial New England: An Enquiry into the Social Context of Literacy in the Early Modern West. New York: W. W. Norton, 1974.

. A New England Town: The First Hundred Years: Dedham, Massachusetts, 1636-1736. New York: W. W. Norton, 1970.

Lockridge, Kenneth A., and Alan Kreider. "The Evolution of Massachusetts Town Government, 1640 to 1740." William and Mary Quarterly 23 (1966): 549-574

Lothrop, Samuel Kirkland. A History of the Church in Brattle Street, Boston. Boston: Wm. Crosby and H. P. Nichols, 1851.

Malmsheimer, Lonna M. "Daughters of Zion: New England Roots of American Feminism.” New England Quarterly 50 (1977): 484-504. 
Masson, Margaret W. "The Typology of the Female as a Model for the Regenerate: Puritan Preaching, 1690-1730." Signs 2, no. 2 (1976): 304-315.

McGiffert, Michael, ed. God's Plot: Puritan Spirituality in Thomas Shepard's Cambridge. 1972. Revised and expanded edition. Amhurst: University of Massachusetts Press, 1994.

McWilliams, James E. “'To Forward Well-Flavored Productions': The Kitchen Garden in Early New England." New England Quarterly 77 (2004): 25-50.

Middlekauff, Robert. The Mathers: Three Generations of Puritan Intellectuals. Berkeley: University of California Press, 1999.

Miller, Arthur. The Crucible. New York: Viking, 1953.

Miller, Joshua. "Direct Democracy and the Puritan Theory of Membership." Journal of Politics 53 (1991): 57-73.

Miller, Perry. "Errand Into The Wilderness." William and Mary Quarterly 10 (1953): 3-32.

—_. "The Half-Way Covenant." New England Quarterly 6 (1933): 676-715.

. The New England Mind: The Seventeenth Century. 1939. Cambridge, MA: Harvard University Press, 1982.

. The New England Mind: From Colony to Province. 1953. Boston: Beacon Press, 1961.

- Orthodoxy in Massachusetts 1630-1650. 1933. Gloucester, MA: Harvard University Press, 1965.

- "The Puritan Theory of the Sacraments in Seventeenth Century New England." Catholic Historical Review 22 (1937): 409-425.

Miller, Perry, and Thomas N. Johnson, eds. The Puritans: A Sourcebook of Their Writings. 2 vols. 1938. New York: Harper \& Row, 1963.

Monaghan, E. Jennifer. "Literacy Instruction and Gender in Colonial New England." American Quarterly 40 (1988): 18-41.

Moran, Gerald F. "Religious Renewal, Puritan Tribalism, and the Family in Seventeenth-Century Milford, Connecticut." William and Mary Quarterly 36 (1979): 236-254. 
—_. "Sisters' in Christ: Women and the Church in Seventeenth-Century New England." In Women in American Religion, edited by Janet Wilson James, 4765. Philadelphia: University of Pennsylvania Press, 1980.

Moran, Gerald F., and Maris A. Vinovskis. "The Puritan Family and Religion: A Critical Reappraisal.” William and Mary Quarterly 39 (1982): 29-63.

Morgan, Edmund S. "New England Puritanism: Another Approach." William and Mary Quarterly 18 (1961): 236-242.

. The Puritan Dilemma: The Story of John Winthrop. $2^{\text {nd }}$ ed. New York: Longman, 1999.

- The Puritan Family: Religion and Domestic Relations in SeventeenthCentury New England. 1944. New York: Harper \& Row, 1966.

- Roger Williams: The Church and the State. New York: Harcourt, 1967.

- Visible Saints: The History of a Puritan Idea. Ithaca, NY: Cornell University Press, 1963.

Morison, Samuel Eliot. Builders of the Bay Colony. 1930. Boston: Houghton Mifflin, 1958.

Norton, Mary Beth. "'The Ablest Midwife That Wee Knowe in the Land': Mistress Alice Tilly and the Women of Boston and Dorchester, 1649-1650." William and Mary Quarterly 55 (1998): 105-134.

- "The Evolution of White Women's Experience in Early America." American Historical Review 89 (1984): 593-619.

- Founding Mothers and Fathers: Gendered Power and the Forming of American Society. New York: Vintage, 1996.

- In the Devil's Snare: The Salem Witchcraft Crisis of 1692. New York: Vintage, 2002.

Palfrey, John Gorham. History of New England during the Stuart Dynasty. 3 vols. Boston: Little, Brown and Company, 1882.

Pestana, Carla Gardina. "The City on a Hill under Siege: The Puritan Perception of the Quaker Threat to Massachusetts Bay, 1656-1661." New England Quarterly 56 (1983): 323-353. 
Peters, Christine. Patterns of Piety: Women, Gender, and Religion in Late Medieval and Reformation England. Cambridge, UK: Cambridge University Press, 2003.

Peterson, Mark A. "From Founding Fathers to Old-Boy Networks: The Declension of Perry Miller's Puritans." Review of Congregational Communion: Clerical Friendship in the Anglo-American Puritan Community, 1610-1692, by Francis J. Bremer, and Orthodoxies in Massachusetts: Rereading American Puritanism, by Janice Knight. Reviews in American History 23 (1995): 13-19.

. The Price of Redemption: The Spiritual Economy of Puritan New England. Stanford, CA: Stanford University Press, 1997.

Pettit, Norman. The Heart Prepared: Grace and Conversion in Puritan Spiritual Life. New Haven, CT: Yale University Press, 1966.

Pope, Robert G. The Half-Way Covenant: Church Membership in Puritan New England. 1969. Eugene, OR: Wipf and Stock Publishers, 2002.

- "New England versus the New England Mind: The Myth of Declension." Journal of Social History 3 (1969-1970): 95-108.

Porterfield, Amanda. Female Piety in Puritan New England: The Emergence of Religious Humanism. New York: Oxford University Press, 1992.

—. "Women's Attraction to Puritanism." Church History 60 (1991): 196-209.

Reis, Elizabeth. Damned Women: Sinners and Witches in Puritan New England. Ithaca, NY: Cornell University Press, 1997.

Robinson, Lewis Milton. "A History of the Half-Way Covenant." PhD diss., University of Illinois, 1963.

Rutman, Darrett B. American Puritanism: Faith and Practice. Philadelphia: J. B. Lippincott, 1970.

Winthrop's Boston: A Portrait of a Puritan Town, 1630-1649. Chapel Hill: University of North Carolina, 1965.

Saxton, Martha. "Bearing the Burden? Puritan Wives." History Today 44 (1994): 2833.

Being Good: Women's Moral Values in Early America. New York: Hill and Wang, 2003. 
Scholz, Robert F. "Clerical Consociation in Massachusetts Bay: Reassessing the New England Way and Its Origins." William and Mary Quarterly 29 (1972): 391414.

Simmons, Richard C. "Godliness, Property, and the Franchise in Puritan Massachusetts: An Interpretation." Journal of American History 55 (1968): 495-511.

- "The Founding of the Third Church in Boston." William and Mary Quarterly 26 (1969): 241-252.

Simpson, Alan. Puritanism in Old and New England. University of Chicago Press, 1955.

Smith, James Morton, ed. Seventeenth-Century America: Essays in Colonial History. Chapel Hill: University of North Carolina Press, 1996.

Starkey, Marion L. The Devil in Massachusetts: A Modern Enquiry into the Salem Witch Trials. 1949. New York: Anchor, 1989.

Stout, Harry S. The New England Soul: Preaching and Religious Culture in Colonial New England. New York: Oxford University Press, 1986.

Stout, Harry S., and Catherine A. Brekus. "Declension, Gender, and the 'New Religious History." In Vandermeer and Swierenga, Belief and Behavior, 1537.

Thompson, Roger. Women in Stuart England and America: A Comparative Study. London: Routledge \& Kegan Paul, 1974.

Ulrich, Laurel Thatcher. Good Wives: Image and Reality in the Lives of Women in Northern New England, 1650-1750. New York: Vintage Books, 1991.

__ "John Winthrop's City of Women." Massachusetts Historical Review 3 (2001): 19-48.

- "Of Pens and Needles: Sources in Early American History." Journal of American History 77 (1990): 200-207.

—. "Vertuous Women Found: New England Ministerial Literature, 1668-1735." American Quarterly 28 (1976): 20-40.

Vandermeer, Philip R., and Robert Swierenga. Belief and Behavior: Essays in the New Religious History. New Brunswick, NJ: Rutgers University Press, 1991. 
Wall, Robert Emmet, Jr. "The Massachusetts Bay Colony Franchise in 1647." William and Mary Quarterly 27 (1970): 136-144.

Welter, Barbara. "The Cult of True Womanhood: 1820-1860." American Quarterly 18 (1966): 151-174.

Westerkamp, Marilyn J. Women and Religion in Early America, 1600-1850: The Puritan and Evangelical Traditions. London: Routledge, 1999.

Winslow, Ola Elizabeth. "And Plead for the Rights of All": Old South Church in Boston, 1669-1969. Boston: The Nimrod Press, 1970.

Wisner, Benjamin B. The History of the Old South Church in Boston, in Four Sermons. Boston: Crocker \& Brewster, 1830.

Ziff, Larzer. Puritanism in America: New Culture in a New World. New York: Viking Press, 1973. 
Appendix A

Timeline

\section{Phase One}

1650 Second (Old North) Church gathered in Boston

1662 Halfway synod releases its result

1663 John Norton (First Church) dies

1667 John Wilson (First Church) dies

Sept. 30, 1667 Dissenters request delay in call to John Davenport Dissenters present their "Reasons of Dissent" First Church extends formal invitation to Davenport

May 2, 1668 Davenport arrives in Boston

Aug. 6, 1668 First council meets in Boston at request of First Church

Aug. 8, 1668 First council result released

Aug. 10, 1668 Dissenters present first request for dismission First Church gives formal call to Davenport

Aug. 19, 1668 Forged New Haven letter read to First Church

Nov. 9, 1668 Davenport given formal call to First Church pulpit

Dec. 9, 1668 Davenport and Allen ordained in First Church

Jan. $24,1668 / 69$ Dissenters refuse to take the Lord's Supper to avoid a snare

Feb. 12, 1668/69 First Church votes to discharge three dissenting deacons

March 31, 1669 Dissenters request a second council

April 13, 1669 Second council meets at Boston

April 16, 1669 Result of the second council

May 1669 Third Church covenanted at Charlestown

June 1669 Forgery of New Haven letter is revealed 


\section{Phase Two}

Feb. 16, 1669/70 Thomas Thatcher ordained as minister of Third Church

Feb. 25, 1669/70 Davenport forbids dissenting wives from taking Supper at Third

Feb. 28, 1669/70 Two sisters meet with Davenport

March 5, 1669/70 Wives' first request for dismission

March 8, 1669/70 Wives submit individual requests for dismission

March 13, 1669/70 Davenport dies

March 25, 1669/70 Church votes to deny women's dismissions

May 3, 1670 John Oxenbridge ordained by First Church

April 24, 1670 Most of the wives take Supper at Third Church

Wives' second request for dismission

First Church votes to deny wives communion

April 28, 1670 Thatcher and Edward Rainsford petition for wives' dismissions

Aug. 1, 1670 Thatcher submits Essay for Accommodation

Dec. 28, 1670 'Thatcher and Rainsford petition again for wives' dismissions

May 1671 Annual General Court election favors Third Church supporters

Oct. 30, 1671 Elder Penn dies

May 7, 1673 Urian Oakes preaches election sermon

June 13, 1673 Thatcher and Rainsford request wives' dismission

Aug. 19, 1673 First Church replies to request

May 1674 Council approves wives' separation from First Church

Aug. 27, 1674 Wives petition for admission to Third Church

Oct. 16, 1674 Wives admitted to Third Church 


\section{Appendix B}

\section{Signatures on Wives' Petitions}

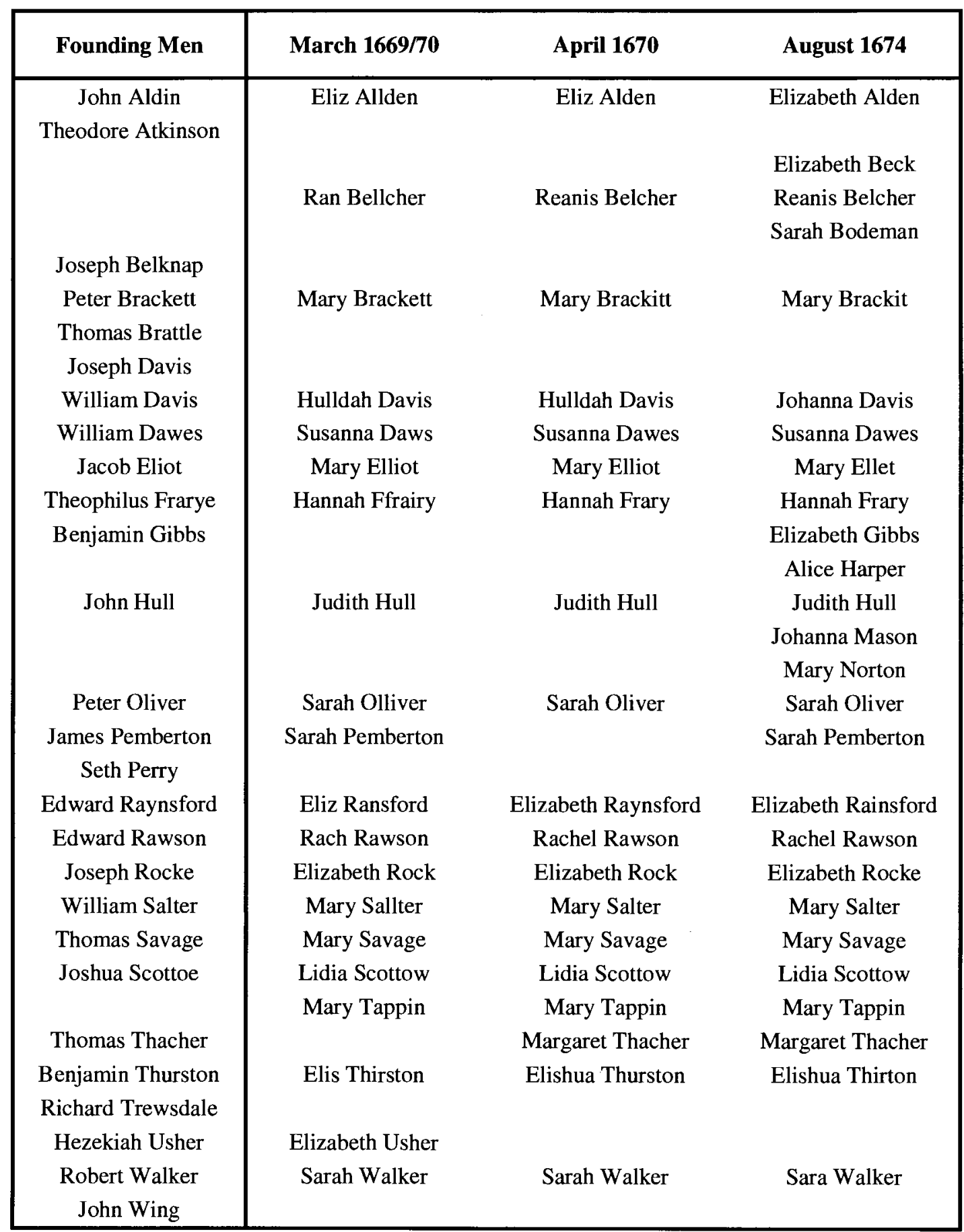

Source: Hamilton Andrews Hill, History of the Old South Church (Third Church) Boston, 1669-1884 (Boston: Houghton, Mifflin, 1890), 113, 165, 168, 202. An image of the women's signatures from the last petition can be found between pages 168 and 169 . 


\section{Appendix C}

\section{Admissions of New Members to First and Third Churches, 1667-1674}

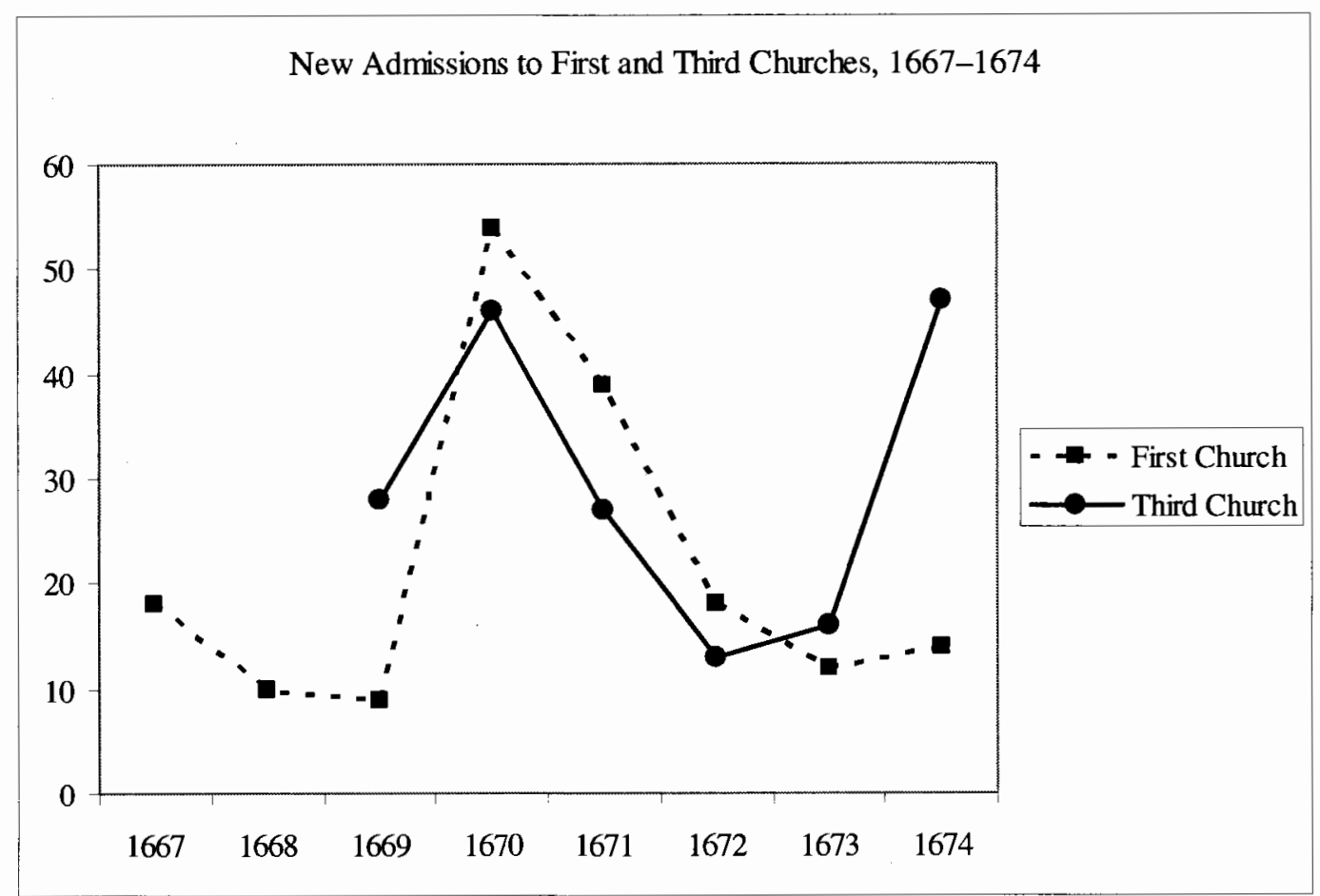

New Admissions to First and Third Churches, 1667-1674

\begin{tabular}{lccccccccc}
\hline & 1667 & 1668 & 1669 & 1670 & 1671 & 1672 & 1673 & 1674 & Total \\
\hline \multirow{2}{*}{ First Church } & 18 & 10 & 9 & 54 & 39 & 18 & 12 & 14 & 174 \\
\hline Third Church & & & 28 & 46 & 27 & 13 & 16 & 47 & 177 \\
\hline
\end{tabular}

Sources: Richard D. Pierce, ed., The Records of the First Church in Boston 1630-1868, Publications of the Colonial Society of Massachusetts 39 (Boston: Colonial Society of Massachusetts, 1961), 63-73; Hamilton Andrews Hill and George Frederick Bigelow, eds., An Historical Catalogue of the Old South Church (Third Church) Boston, 1669-1882 (Boston: David Clapp \& Son, 1883), 5-10; Robert G. Pope, The Half-Way Covenant: Church Membership in Puritan New England (1969; Eugene, OR: Wipf and Stock, 2002), 282, 284. 


\section{New Admissions to First Church by Gender, 1667-1674}

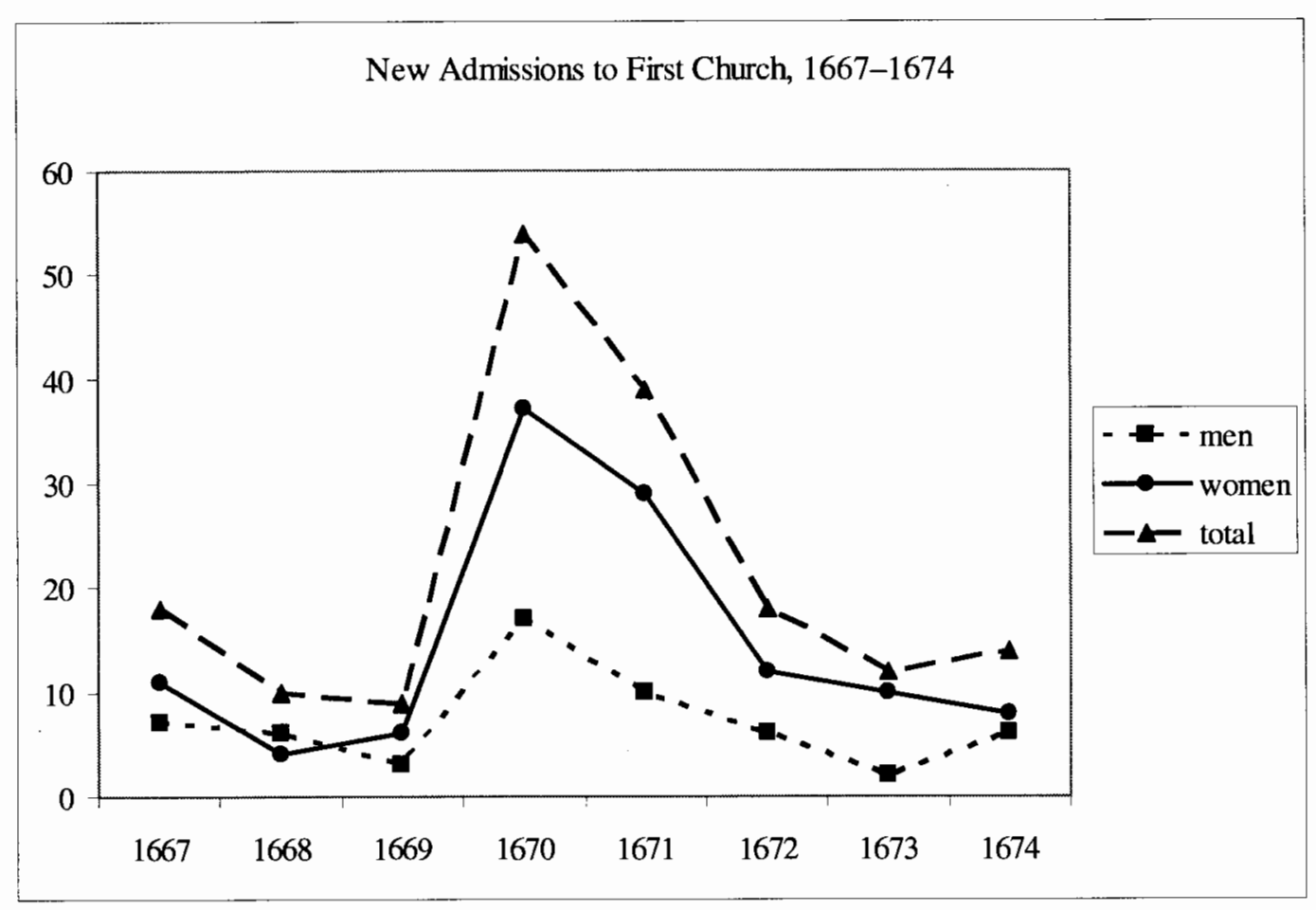

New Admissions to First Church, 1667-1674

\begin{tabular}{rccccccccc}
\hline & 1667 & 1668 & 1669 & 1670 & 1671 & 1672 & 1673 & 1674 & Total \\
\hline Men & 7 & 6 & 3 & 17 & 10 & 6 & 2 & 6 & 57 \\
\hline Women & 11 & 4 & 6 & 37 & 29 & 12 & 10 & 8 & 117 \\
\hline Total & 18 & 10 & 9 & 54 & 39 & 18 & 12 & 14 & 174 \\
\hline
\end{tabular}

Source: Richard D. Pierce, ed., The Records of the First Church in Boston 1630-1868, Publications of the Colonial Society of Massachusetts 39 (Boston: Colonial Society of Massachusetts, 1961), 63-73. 


\section{New Admissions to Third Church by Gender, 1669-1674}

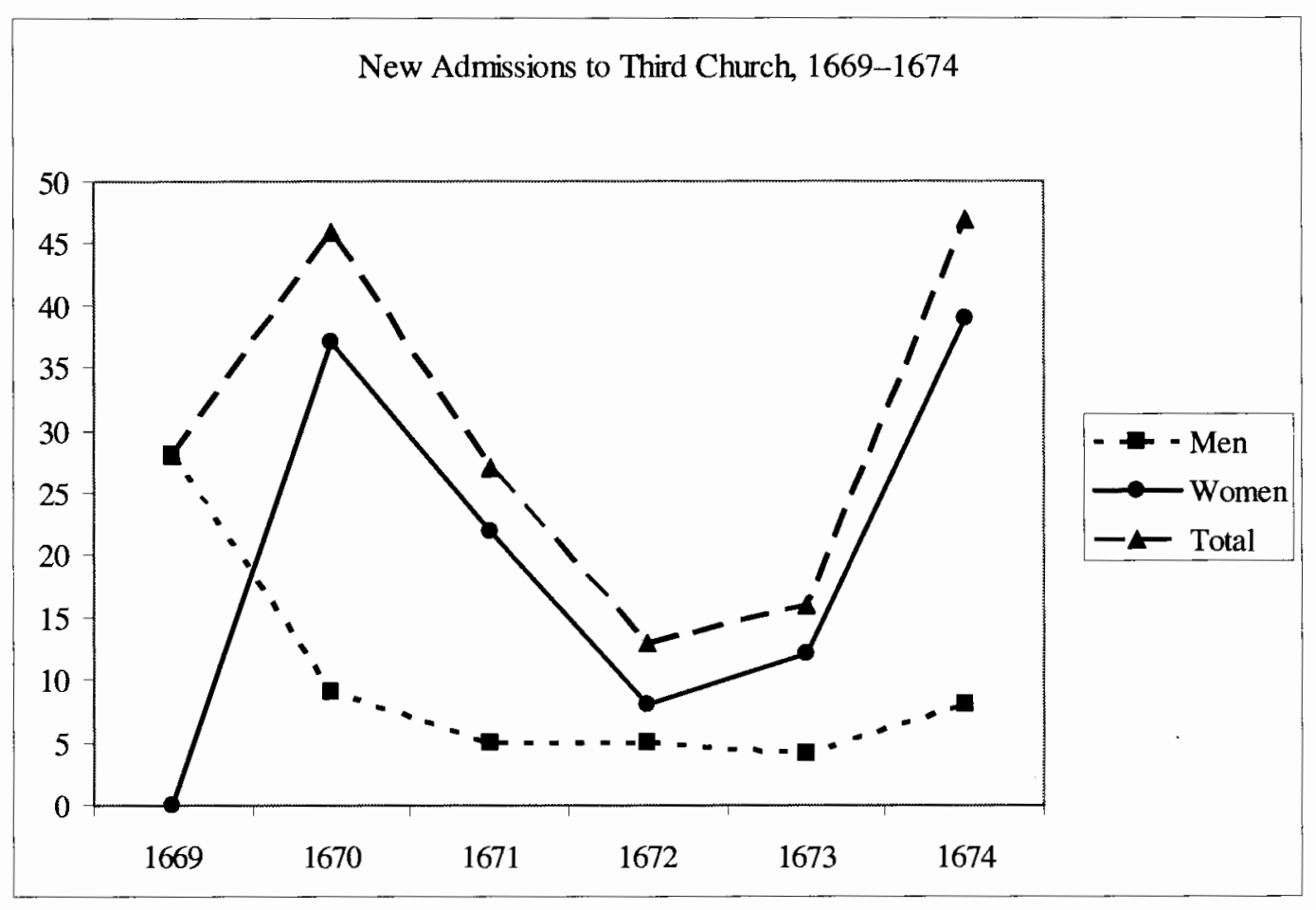

New Admissions to Third Church, 1669-1674

\begin{tabular}{rccccccc}
\hline & 1669 & 1670 & 1671 & 1672 & 1673 & 1674 & Total \\
\hline Men & 28 & 9 & 5 & 5 & 4 & 8 & 59 \\
\hline Women & & 37 & 22 & 8 & 12 & 39 & 118 \\
\hline Total & 28 & 46 & 27 & 13 & 16 & 47 & 177 \\
\hline
\end{tabular}

Sources: Hamilton Andrews Hill and George Frederick Bigelow, eds., An Historical Catalogue of the Old South Church (Third Church) Boston, 1669-1882 (Boston: David Clapp \& Son, 1883), 5-10; Robert G. Pope, The Half-Way Covenant: Church Membership in Puritan New England (1969; Eugene, OR: Wipf and Stock, 2002), 282, 284. 


\section{New Admissions of Women to First and Third Churches, 1667-1674}

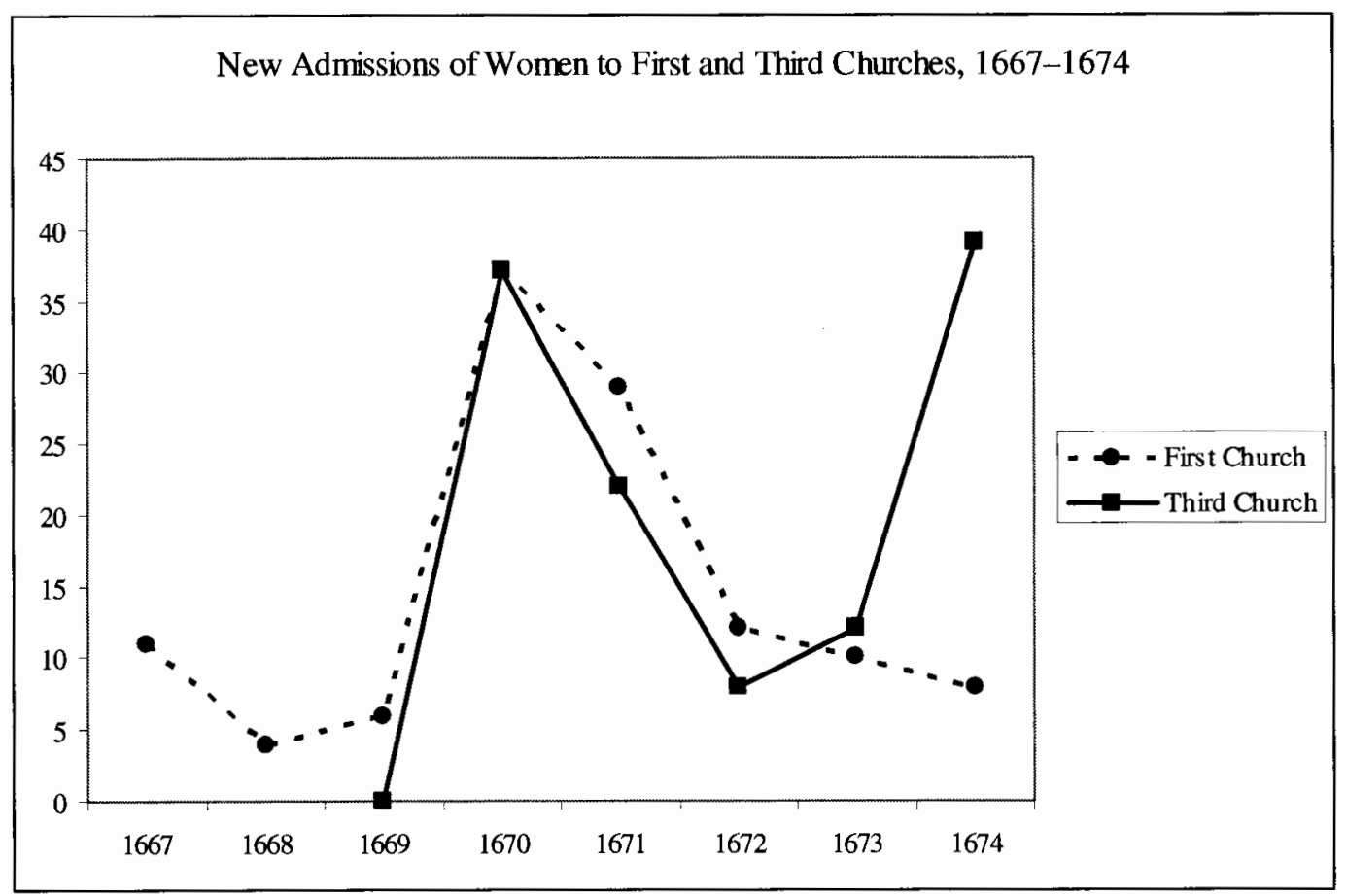

New Admissions of Women to First and Third Churches, 1667-1674

\begin{tabular}{lccccccccc}
\hline & 1667 & 1668 & 1669 & 1670 & 1671 & 1672 & 1673 & 1674 & Total \\
\hline First Church & 11 & 4 & 6 & 37 & 29 & 12 & 10 & 8 & 117 \\
\hline Third Church & & & 0 & 37 & 22 & 8 & 12 & 39 & 118 \\
\hline
\end{tabular}

Sources: Richard D. Pierce, ed., The Records of the First Church in Boston 1630-1868, Publications of the Colonial Society of Massachusetts 39 (Boston: Colonial Society of Massachusetts, 1961), 63-73; Hamilton Andrews Hill and George Frederick Bigelow, eds., An Historical Catalogue of the Old South Church (Third Church) Boston, 1669-1882 (Boston: David Clapp \& Son, 1883), 5-10; Robert G. Pope, The Half-Way Covenant: Church Membership in Puritan New England (1969; Eugene, OR: Wipf and Stock, 2002), 282, 284. 